 \\ Annual Outlook for U.S. Electric Power 1985}

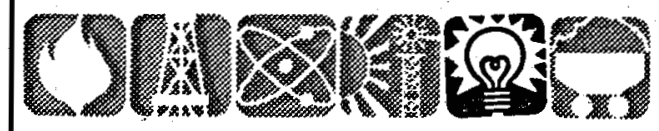

Energy Information Administration Office of Coal, Nuclear, Electric and Alternate Fuels

Washington, DC 20585
DOE/EIA-0474(85)

Distribution Category UC-98

DOE/EIA- -0474 (85)

\section{DE85 016937}

\title{
DISCLAIMER
}

This report was prepared as an account of work sponsored by an agency of the United States Government. Neither the United States Government nor any agency thereof, nor any of their employees, makes any warranty, express or implied, or assumes any legal liability or responsibility for the accuracy, completeness, or usefulness of any information, apparatus, product, or process disclosed, or represents that its use would not infringe privately owned rights. Reference herein to any specific commercial product, process, or service by trade name, trademark, manufacturer, or otherwise does not necessarily constitute or imply its endorsement, recommendation, or favoring by the United States Government or any agency thereof. The views and opinions of authors expressed herein do not necessarily state or reflect those of the United States Government or any agency thereof.

\section{Published: August 1985}

This report was prepared by the Energy Information Administration, the independent statistical and analytical agency within the Department of Energy. The information contained herein should not be construed as advocating or necessarily reflecting any policy position of the Department of Energy or any other organization. 


\section{DISCLAIMER}

This report was prepared as an account of work sponsored by an agency of the United States Government. Neither the United States Government nor any agency Thereof, nor any of their employees, makes any warranty, express or implied, or assumes any legal liability or responsibility for the accuracy, completeness, or usefulness of any information, apparatus, product, or process disclosed, or represents that its use would not infringe privately owned rights. Reference herein to any specific commercial product, process, or service by trade name, trademark, manufacturer, or otherwise does not necessarily constitute or imply its endorsement, recommendation, or favoring by the United States Government or any agency thereof. The views and opinions of authors expressed herein do not necessarily state or reflect those of the United States Government or any agency thereof. 


\section{DISCLAIMER}

Portions of this document may be illegible in electronic image products. Images are produced from the best available original document. 


\section{Contacts}

General information regarding the preparation and content of this publication may be obtained from Robert T. Eynon, Chief of the Data Analysis and Forecasting Branch (202/252-9855), or Thomas Petersik (202/252-9171).

This report was prepared in the Office of Coal, Nuclear, Electric and Alternate Fuels by Melvin Johnson (Appendix A), Jeffrey Jones (Chapter 4 and Appendix C), James Kendell (Chapter 2), John Makens (Chapter 3), and Thomas Petersik (Chapters 1, 5, and Appendix B).
To obtain additional copies, write or contact:

National Energy Information Center

U.S. Department of Energy

1000 Independence Avenue

Washington, DC 20585

(202) 252-8800

\section{Photo Credits}

- Executive Summary: Edison Electric Institute, photo 1; Reddy Kilowatt is a Federally registered trademark and service mark used here with permission of Reddy Communications, Inc., photo 2. - Chapter 1: Niagara Mohawk Corporation, photo 1; Tennessee Valley Authority, photo 2; Duquesne Light Company, photo 3. - Chapter 3: The Lighting Business Group of the General Electric Company, photo 1, the American Electric Power Service Corporation, photos 2 and 3. - Chapter 5: Lucky Peak Power Plant Project, photo 1. Appendix A: U.S. Bureau of Reclamation, photo 1. 


\section{Preface}

Section 205(a)(2) of the Department of Energy Organization Act (Public Law 95-91) requires the Administrator of the Energy Information Administration (EIA) to carry out a central, comprehensive, and unified energy data information program. EIA's responsibility is to provide timely, high-quality information and to perform objective, credible analyses in support of deliberations by both public and government decisionmakers.

Electricity is one of the major areas of concern for EIA. Electricity use plays a large and growing role in the U.S. economy, and continues to increase in every end-use sector. These increases have occurred despite rising prices and growing emphasis on energy conservation, over a period when total U.S. energy consumption has declined. Furthermore, U.S. electricity use is projected to continue increasing, capturing a much larger share of U.S. energy markets.

The Annual Outlook For U.S. Electric Power 1985 provides a history and projections of U.S. electric utility markets. It includes summary information on the production of electricity, its distribution to end-use sectors, and on electricity costs and prices. Further, this publication describes the ownership structure of the industry and the operations of utility systems and outlines basic electricity generating technologies. The historical information covers the period from 1882 through 1984, while projections extend from 1985 through 1995. 


\section{Contents}

1. HISTORY OF THE U.S. ELECTRIC UTILITY INDUSTRY $\ldots \ldots \ldots \ldots \ldots \ldots \ldots \ldots \ldots \ldots \ldots$

Beginnings: 1882-1900 $\ldots \ldots \ldots \ldots \ldots \ldots \ldots \ldots \ldots \ldots \ldots \ldots \ldots \ldots \ldots \ldots \ldots \ldots \ldots \ldots \ldots . \ldots \ldots$

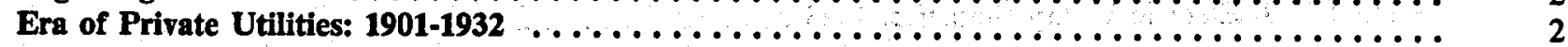

Emergence of Federal Power: $1933-1950 \ldots \ldots \ldots \ldots \ldots \ldots \ldots \ldots \ldots \ldots \ldots \ldots \ldots \ldots \ldots \ldots \ldots$

Utility Prosperity: $1951-1970 \ldots \ldots \ldots \ldots \ldots \ldots \ldots \ldots \ldots \ldots \ldots \ldots \ldots \ldots \ldots \ldots \ldots \ldots \ldots \ldots \ldots .6$

Years of Challenge: $1971-1984 \ldots \ldots \ldots \ldots \ldots \ldots \ldots \ldots \ldots \ldots \ldots \ldots \ldots \ldots \ldots \ldots \ldots \ldots \ldots . \ldots 7$

2. THE STRUCTURE OF THE U.S. ELECTRIC UTILITY INDUSTRY $\ldots \ldots \ldots \ldots \ldots \ldots \ldots \ldots \ldots$

Ownership Structure $\ldots \ldots \ldots \ldots \ldots \ldots \ldots \ldots \ldots \ldots \ldots \ldots \ldots \ldots \ldots \ldots \ldots \ldots \ldots \ldots \ldots \ldots \ldots 11$

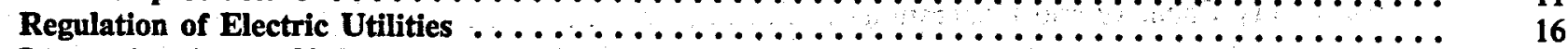

Interaction Among Utilities $\ldots \ldots \ldots \ldots \ldots \ldots \ldots \ldots \ldots \ldots \ldots \ldots \ldots \ldots \ldots \ldots \ldots \ldots \ldots \ldots \ldots$

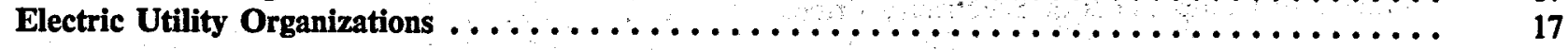

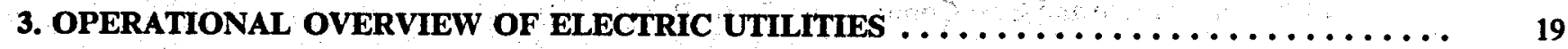

Introduction $\ldots \ldots \ldots \ldots \ldots \ldots \ldots \ldots \ldots \ldots \ldots \ldots \ldots \ldots \ldots \ldots \ldots \ldots \ldots \ldots \ldots \ldots \ldots$

Customer Requirements $\ldots \ldots \ldots \ldots \ldots \ldots \ldots \ldots \ldots \ldots \ldots \ldots \ldots \ldots \ldots \ldots \ldots \ldots \ldots \ldots \ldots \ldots \ldots . \ldots \ldots$

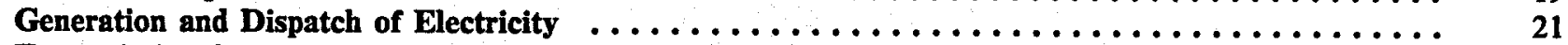

Transmission Systems $\ldots \ldots \ldots \ldots \ldots \ldots \ldots \ldots \ldots \ldots \ldots \ldots \ldots \ldots \ldots \ldots \ldots \ldots \ldots \ldots \ldots . \ldots \ldots$

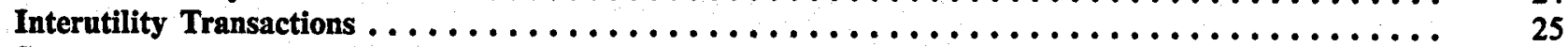

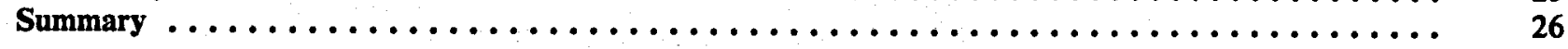

4. OUTLOOK FOR ELECTRIC POWER, $1985-1995 \ldots \ldots \ldots \ldots \ldots \ldots \ldots \ldots \ldots \ldots \ldots \ldots \ldots$

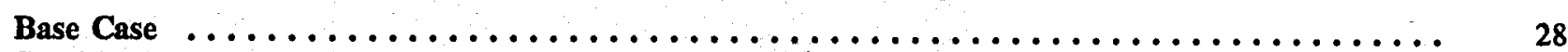

Sensitivities $\ldots \ldots \ldots \ldots \ldots \ldots \ldots \ldots \ldots \ldots \ldots \ldots \ldots \ldots \ldots \ldots \ldots \ldots \ldots \ldots \ldots \ldots \ldots \ldots \ldots \ldots{ }_{31}$

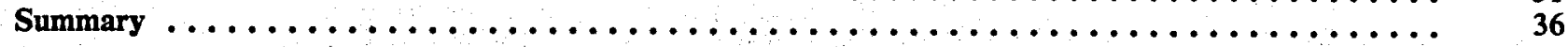

5. FACTORS AFFECTING THE OUTLOOK FOR ELECTRIC POWER $\ldots \ldots \ldots \ldots \ldots \ldots \ldots \ldots \ldots \ldots$

Bulk Power Transactions $\ldots \ldots \ldots \ldots \ldots \ldots \ldots \ldots \ldots \ldots \ldots \ldots \ldots \ldots \ldots \ldots \ldots \ldots \ldots \ldots \ldots$

Coal-Fired Power Plant Life Extension $\ldots \ldots \ldots \ldots \ldots \ldots \ldots \ldots \ldots \ldots \ldots \ldots \ldots \ldots \ldots \ldots \ldots \ldots$

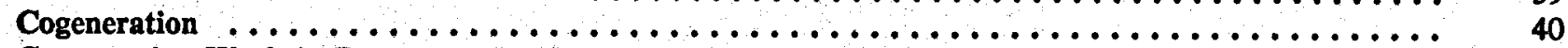

Construction Work in Progress $\ldots \ldots \ldots \ldots \ldots \ldots \ldots \ldots \ldots \ldots \ldots \ldots \ldots \ldots \ldots \ldots \ldots \ldots \ldots \ldots \ldots, 41$

Revisions to Federal Tax Law $\ldots \ldots \ldots \ldots \ldots \ldots \ldots \ldots \ldots \ldots \ldots \ldots \ldots \ldots \ldots \ldots \ldots \ldots \ldots \ldots \ldots \ldots, \ldots$

Sulfur Dioxide Emissions Control $\ldots \ldots \ldots \ldots \ldots \ldots \ldots \ldots \ldots \ldots \ldots \ldots \ldots \ldots \ldots \ldots \ldots \ldots \ldots \ldots \ldots, 42$

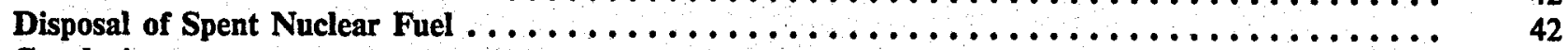

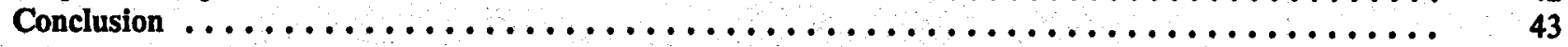

Appendix

A. TECHNOLOGIES OF ELECTRIC POWER GENERATION $\ldots \ldots \ldots \ldots \ldots \ldots \ldots \ldots \ldots \ldots$

Principles of Electric Power Generation $\ldots \ldots \ldots \ldots \ldots \ldots \ldots \ldots \ldots \ldots \ldots \ldots \ldots \ldots \ldots \ldots \ldots \ldots$

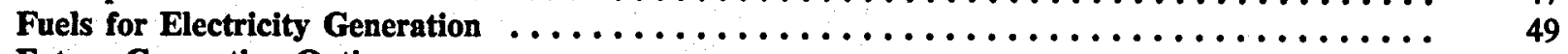

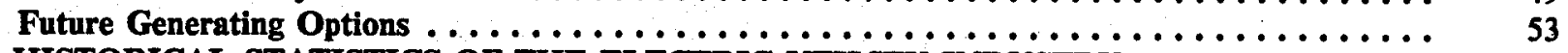

B. HISTORICAL STATISTICS OF THE ELECTRIC UTILITY INDUSTRY $\ldots \ldots \ldots \ldots \ldots \ldots . \quad 59$

C. MIDDLE ECONOMIC GROWTH CASE: REGIONAL PROJECTIONS $\ldots \ldots \ldots \ldots \ldots \ldots \ldots$ 


\section{Tables}

Page

1. Historical and Projected Ratios, Average Annual Rates of Growth of U.S. Net Electricity Generation to Real Gross National Product, 1900-1990

2. Selected U.S. Electric Utility Statistics, $1983 \ldots \ldots \ldots \ldots \ldots \ldots \ldots \ldots \ldots \ldots \ldots \ldots \ldots \ldots$

3. U.S. Electric Utility Revenue From Sales to Ultimate Consumers, $1983 \ldots \ldots \ldots \ldots$

4. Sources of Capital in the U.S. Electric Utility Industry, by Ownership Type . . . . . . 13

5. Total End-Use Energy Consumption and Electricity Sales, Selected Years $\ldots \ldots \ldots \ldots$

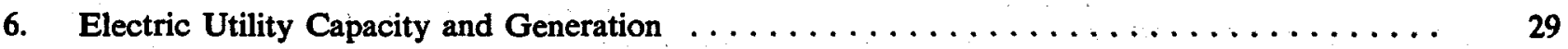

7. Summary of Components of Electricity Price $\ldots \ldots \ldots \ldots \ldots \ldots \ldots \ldots \ldots \ldots \ldots \ldots$

8. Projected Electricity Price and Cost Components, Low, Base, and High Economic Growth Cases, 1995 


\section{Illustrations}

Page

1. Net Generation by U.S. Electric Utilities, $1902-1984 \ldots \ldots \ldots \ldots \ldots \ldots \ldots \ldots \ldots \ldots$

2. Areas Served by Power Marketing Administrations and Tennessee Valley Authority ...... 14

3. Location of Municipal and Other Public Utilities $\ldots \ldots \ldots \ldots \ldots \ldots \ldots \ldots$

4. North American Electric Reliability Council Regions $\ldots \ldots \ldots \ldots \ldots \ldots \ldots$

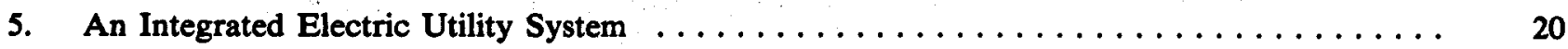

6. Typical Generation Dispatch, Summer Peak Day $\ldots \ldots \ldots \ldots \ldots \ldots \ldots \ldots \ldots \ldots \ldots$

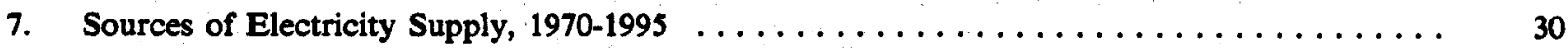

8. End-Use Electricity Consumption: Comparison of Economic Growth Scenarios, Selected Years 33

9. Projected Sources of Electrical Supply: Comparison of Economic Growth Scenarios, Selected

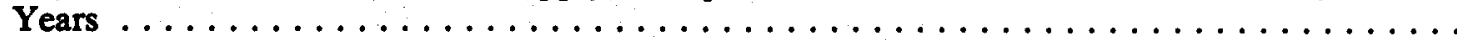




\section{EXECUTIVE SUMMARY}

The electric utility industry began in 1882 , just over 100 years ago. Today electricity is vital to virtually every aspect of the U.S. economy and is projected to continue to expand its role over the next decade. This Annual Oitlook for U.S. Electric Power 1985 describes the U.S. electric utility industry over this 100-year period and projects major electric utility market characteristics through 1995 . It also describes the ownership structure of the industry, presents an operational overview of electric utility systems, and outlines basic electricity generation technologies.

\section{History and Structure of the U.S. Electric Utility Industry}

From the beginning of the 20th century to the end of 1984, net electricity generation has increased at an annual average rate of nearly 9 percent, almost triple the rate of growth of real Gross National Product (GNP) (Appendix B and Table 1). The more rapid growth in electricity consumption has been the result of both declining prices and changes in technology that increased demand. Price declines are attributed to growing technical efficiencies in electricity generation; demand changes have increasingly favored the use of electricity for producer and consumer goods and

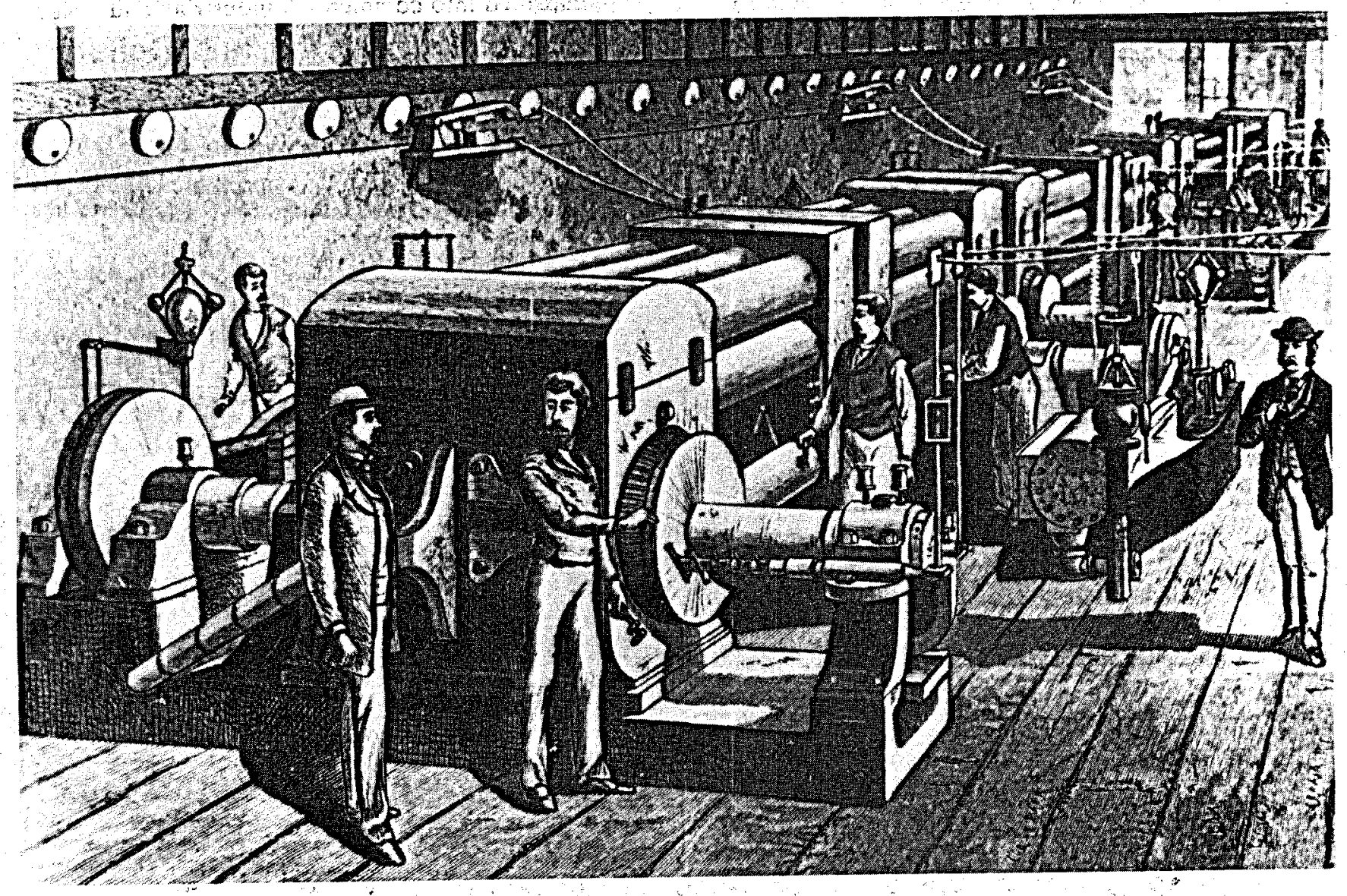

Pearl Street, New York City, 1882-generators of the first modern electricity generating station (120 kilowatts). 
services. Real residential prices have declined at just over 4 percent a year (Figure ES1 and Appendix B).

However, long-term electricity rates of growth and electricity growth rates compared to GNP have declined in recent years. A slowdown in electricity growth began in the 1970's, as electricity prices began rising in response to rapidly increasing utility costs. A general economic downturn in 1982 induced the first absolute decline in utility generation since 1945 . Since 1982, however, electricity generation has recovered, increasing to record highs in 1983 and 1984, although not at historically high rates of growth.

The U.S. electric power industry is a combination of private, Federal, and public nonprofit organizations. Private investor-owned utilities (IOU's) dominate the industry, accounting for about three-quarters of capacity, generation, number of customers, and sales to ultimate consumers. Other ownership groups play secondary roles. Federal power ranks second in capacity and generation, while municipal utilities and cooperatives rank second in number of customers and third in volume of sales to ultimate consumers.

The electric utility industry is regulated at the local, State, and Federal levels. State regulation includes jurisdiction over electricity prices (rates), services, safety, and construction. The Federal Energy
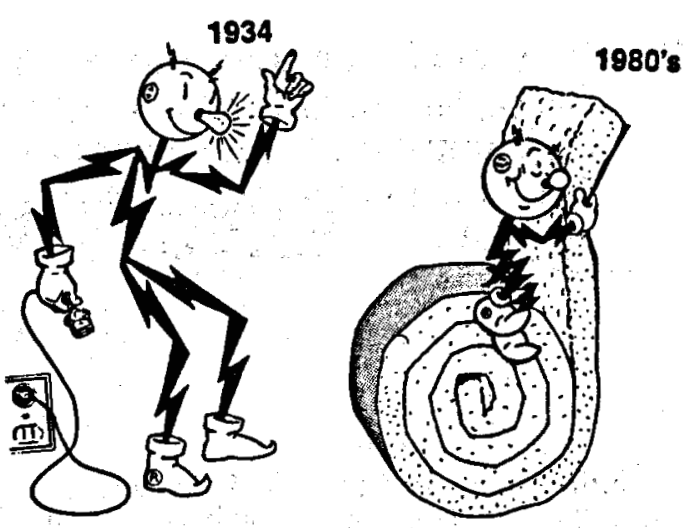

Reddy Kllowatt introduced electricity in the 1930's, promoted increased use in the next 3 decades, and now encourages conservation and wise energy use.

Regulatory Commission (FERC) is the primary Federal regulator of electric utilities.

A comprehensive electric utility system is an integrated group of facilities that generate, transmit, and distribute electricity to consumers. Its operations are unified and coordinated by an operations control center that is also interconnected with other utility systems. Utilities also cooperate in bulk power sales and joint generation and transmission projects. Customers are classified into commercial, industrial, and residen-

\section{Figure ES1. Residential Electricity Prices, 1902-1984, Current and 1972 Dollars}

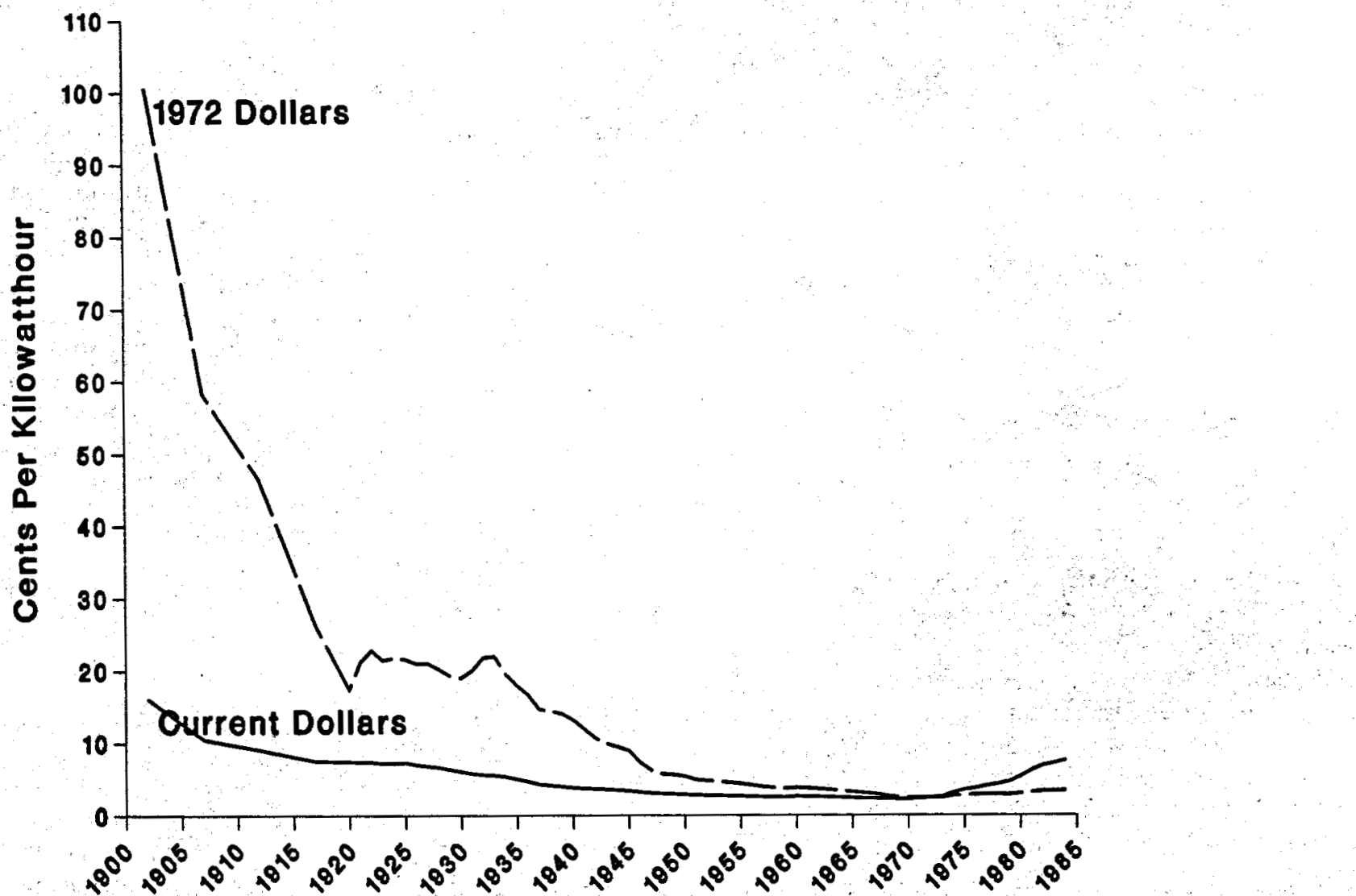

Sources: - 1902: U.S. Bureau of the Census, Historical Statistics of the United States, Colonial Times to 1970, Bicentennial Edition, Part 2 (September 1975), p. 827; • 1907-1959: Edison Electric Institute, Historical Statistics of the Electric Utility Industry Through 1970 (1973), p. 165; • 1960-1984: Energy Information Administration, Annual Energy Review 1984 (April 1985), p. 187. 


\section{Table ES1. Projected Average Annual Growth Rates of Electriclty Sales, Gross National Product, and Nonelectriclty Energy Consumption Under Alternate Economic Growth Assumptions, 1985-1995 \\ (Percent)}

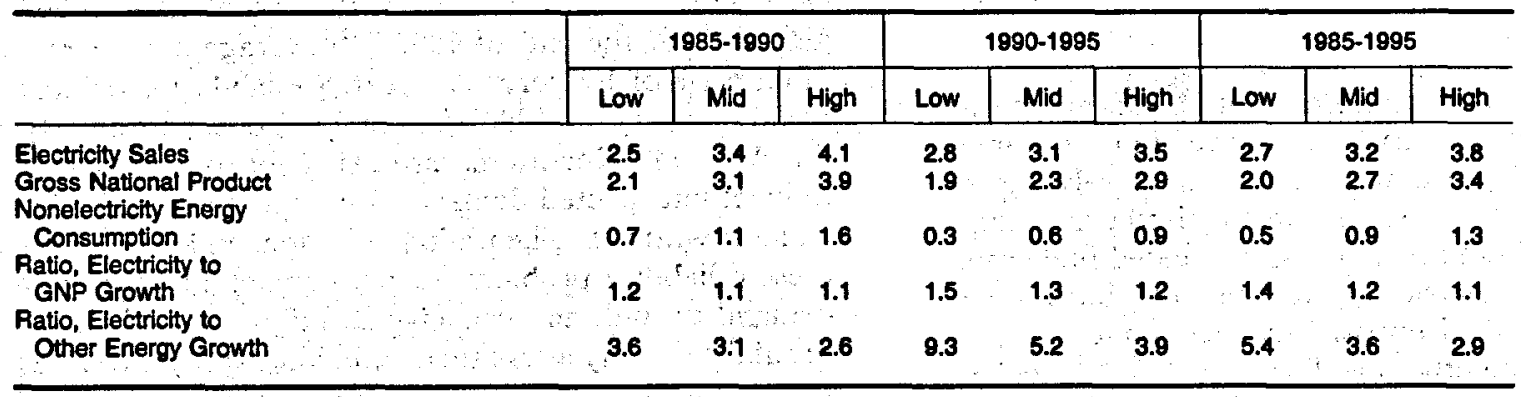

c11.

Source: Energy Information Administration, Annual Energy Outlook 1984 (January 1985), p. 8, Tables A3, A11, B3, B11, C3,

tial classes. They may also be categorized by their willingness to permit interruptions of electricity service:

Large, "baseload" plants that are expensive to build but economical to operate are used by electric utilities to meet the constant portion of electricity demand. "Intermediate" plants have higher operating costs and handle loads not covered by baseload plants. Smaller, "peaking" plants are less expensive to build but are the most expensive to operate and are used to meet high temporary loads. Utilities also maintain generating reserves to meet unusually high demands or to replace units that have been shut down.

The power transmission system is comprised of two components, the bulk power system and the power distribution network. The bulk power system integrates power produced by utilities and carries it at high voltages to substations for distribution; the power distribution network then moves the power to electricity consumers.

\section{Outlook for Electric Power, 1985-1995}

EIA projects that the growth rate of electricity consumption from 1985 through 1995 will increase at a faster rate than both GNP and all other energy use. Electricity's projected U.S. average growth rate of $\mathbf{3 . 2}$ percent a year over that period is greater than the 2.1 percent average growth rate experienced from 1980 through 1984, but well below the average growth rate of almost 9 percent that has been observed since 1900 . Demand growth also shows considerable regional variation, with the lowest projected increases in the
New York/New Jersey region and the highest in the Northwest (Appendix C).

Table ES1 presents expected growth rates of electricity consumption, GNP, and nonelectricity energy consumption for assumed low, base, and high economic growth cases. Over the 1985-1995 period, electricity demand is projected to grow from 10 to 40 percent more rapidly than GNP, with the base-case growth rate for 1985 through 1995 averaging more than three times that of nonelectricity energy consumption. Electricity's higher rate of growth reflects growing customer preference for its versatility, convenience, and price.

Industrial electricity use is expected to grow more rapidly than commercial or residential use over the 1985-1995 period. Between 1985 and 1995, industrial energy use is projected to increase from 35 percent to 39 percent of total electricity consumption, while the commercial and residential sectors' shares decline but remain approximately equal to each other. Virtually all increases in residential energy consumption are projected to be supplied by electricity. In the commercial sector, electricity is expected to increase from 39 percent of energy consumption in 1985 to 44 percent in 1995, reflecting growing commercial consumer preference for electricity. Industrial electricity use is expected to be particularly responsive to changes in overall economic growth. By 1995 industrial electricity use accounts for 37 percent of total electricity consumption in the low economic growth case, whereas in the high economic growth case, industrial use comprises more than 40 percent. ${ }^{1}$

In the base case over the 1985-1995 forecast period, electricity demand growth is encouraged by a projected slight decline in electricity prices. Real electricity prices in 1990 are projected to be about 1 percent below 1985 levels, although slight increases occur through 1987; by 1995 they are projected to be about

'Energy Information Administration, Annual Energy Outlook 1984, DOE/EIA-0383(84) (Washington, DC, January 1985), Tables B11, C11. 
3 percent below 1985 levels. These declines during the 1985-1995 period occur while the average real price of all energy (including electricity) is projected to rise by almost 25 percent. ${ }^{2}$ The projected electricity price declines are predicated on reductions in new generating capacity construction over the forecast period, reducing the capital share of projected electricity prices.

The forecasts also show that electricity prices are sensitive to the type of capacity used. In the high economic growth case, utilities could be forced to rely more extensively on higher cost oil- and gas-fired generating capacity. In this high growth case, increased fuel costs yield higher real electricity prices in 1995 , more than 1 percent above 1985 levels. Low economic growth assumptions, on the other hand, reduce dependence on oil- and gas-fired capacity, and result in 1995 real electricity prices more than 6 percent below the high economic growth case.

Over the 1985-1995 forecast period, increasing dependence on nuclear and coal-fired generating capacity is expected, decreasing the generation share attributed to oil and natural gas (Table ES2). In the base case, 87.6 percent of all projected new capacity is expected to be nuclear or coal-fired steam generating units. However, both coal and nuclear capacity additions decrease in the early and mid-1990's, resulting in a partial recovery of the oil and gas generation share by $1995 .{ }^{3}$ Overall the nuclear and coal-fired share of total generation is expected to increase from 72 percent in 1985 to about 75 percent in 1995.

Consumption of the marginal fuels in electricity generation, oil and natural gas, is projected to be sensitive to the level of overall demand. In 1995 under low economic growth assumptions, oil- and gas-fired generating units are projected to provide 14 percent of total generation; base-case assumptions yield a 16 percent share; and assumptions of high economic growth result in nearly a 19 percent oil and gas share (Table ES2).

Total nameplate generating capacity (excluding outof-service units or inactive reserves) is projected to increase from 663 gigawatts at the end of 1984 to 792 gigawatts at the end of 1995 , an average annual rate of increase of 1.6 percent a year. Reliability problems could occur in the 1990's as some regions, particularly the West and Northwest, are expected to be less able to meet unexpected demand or compensate for equipment downtimes. The timing, location, and severity of these reliability problems depend on actual electricity demand growth and capacity additions, as well as on the ability of any alternate demand or supply measures to mitigate the need for additional capacity. If new coal-fired and nuclear generating units are not put into place as rapidly as currently projected, the Nation could become more dependent on oil- and gas-fired generation and incur increased oil imports, higher electricity prices, and decreased electricity supply reliability. On the other hand, conservation, imports, load management, or increased production from other sources could mitigate these effects.

Other factors may also affect electric power markets over the forecast period, including bulk power purchases and sales of electricity among electric utilities and life extension (refurbishment) of aging coal-fired steam capacity. Electricity produced by nonutility industrial cogenerators could also contribute to reduced demand for new electric utility generating capacity. Sale of cogenerated electricity is now encouraged by the Public Utility Regulatory Policies Act of 1978 (PURPA, P.L. 95-617) requiring utilities to buy cogenerated power. Possibly as much as 5 to 20 percent of U.S. electricity consumption could be provided by such sources in the future. ${ }^{4}$

\section{Table ES2. Electric Utility Net Generation by Fuel Type, 1985, 1995}

(Billion Kilowatthours)

\begin{tabular}{|c|c|c|c|c|c|c|c|c|c|}
\hline \multirow{2}{*}{\multicolumn{2}{|c|}{ Fuel Type }} & \multicolumn{2}{|c|}{$\begin{array}{c}1985 \\
\text { Base Case }\end{array}$} & \multicolumn{2}{|c|}{$\begin{array}{l}\text { Low Economic } \\
\text { Growth Case }\end{array}$} & \multicolumn{2}{|c|}{$\begin{array}{c}1995 \\
\text { Base Case }\end{array}$} & \multicolumn{2}{|c|}{$\begin{array}{l}\text { High Economic } \\
\text { Growth Case }\end{array}$} \\
\hline & & Quantity & $(\%)$ & Quantity & $(\%)$ & Quantity & $(\%)$ & Quantity & $(\%)$ \\
\hline $\begin{array}{l}\text { Coal } \\
\text { Natural Gas } \\
\text { Oil : } \\
\text { Nuclear Power } \\
\text { All Hydropower' }\end{array}$ & & $\begin{array}{r}1,422 \\
301 \\
109 \\
372\end{array}$ & $\begin{array}{r}57.1 \\
12.1 \\
4.4 \\
14.9\end{array}$ & $\begin{array}{r}1,816 \\
323 \\
125 \\
644\end{array}$ & $\begin{array}{r}56.4 \\
10.0 \\
3.9 \\
20.0\end{array}$ & $\begin{array}{r}1,906 \\
349 \\
190 \\
644\end{array}$ & $\begin{array}{r}56.0 \\
10.3 \\
5.6 \\
18.9\end{array}$ & $\begin{array}{r}1,972 \\
286 \\
391 \\
644\end{array}$ & $\begin{array}{r}54.7 \\
7.9 \\
10.8 \\
17.9\end{array}$ \\
\hline $\begin{array}{l}\text { Othere } \\
\text { Total }\end{array}$ & & $\begin{array}{r}289 \\
2,492\end{array}$ & $\begin{array}{r}11.6 \\
100.0\end{array}$ & $\begin{array}{r}313 \\
3,221\end{array}$ & $\begin{array}{r}9.7 \\
100.0\end{array}$ & $\begin{array}{r}312 \\
3,401\end{array}$ & $\begin{array}{r}9.2 \\
100.0\end{array}$ & $\begin{array}{r}315 \\
3,606\end{array}$ & $\begin{array}{r}8.7 \\
100.0\end{array}$ \\
\hline
\end{tabular}

- This category includes conventional and pumped storage hydropower and other renewable sources such as geothermal power, wood, waste, solar energy, and wind.

Note: Totals may not equal sum of components because of independent rounding.

Source: Energy Information Administration, Annual Energy Outlook 1984 (January 1985), Tables A12, B12, and C12.

${ }^{2}$ Energy Information Administration, Annual Energy Outlook 1984, Table As.

${ }^{3}$ Energy Information Administration, Annual Energy Outlook 1984, Table A13.

4Energy Information Administration, Annual Energy Outlook 1984, p. 153. 
Changes in utility construction financing methods may also affect future electricity prices. Wider use of the Cohstruction Work in Progress (CWIP) financing method would allow immediate addition of construction costs to the rate base, thereby raising electricity prices in the short term but lowering them in the longer term by removing both some construction costs and all carrying charges from the long-term rate base. On the other hand, consequences of "rate shock" (sharply raised electricity prices following the addition of expensive new capacity to the rate base), including drops in electricity consumption or public utility commission disallowance of some costs, could discourage some utilities from building new capacity.

Revisions to Federal tax law could also affect electricity prices. A proposal by the Department of the Treasury would reduce the corporate tax rate, allow a 10-percent tax deduction for dividend payments, and shorten depreciation schedules. At the same time, the proposal would eliminate the investment tax credit, require amortization of currently expensed interest costs incurred during construction, require repayment of tax benefits associated with the accelerated cost recovery system (ACRS) for depreciation, and impose a minimum corporation income tax of 20 percent. Overall the proposal, if enacted, is expected to lower most utilities' Federal tax liabilities and lower electricity prices to ratepayers.
Proposals to reduce sulfur dioxide emissions from coalfired generating plants could raise future electricity prices by requiring expensive emissions control measures. Under all proposals examined by the Energy Information Administration, electricity prices could be increased between 3 and 5 percent as utilities install flue gas desulfurization (FGD) equipment costing $\$ 10$ to \$26 billion, pay higher fuel costs, and incur increased operating and maintenance expenditures. Regional coal markets could also be affected as utilities switch coal types to meet legal requirements.

Finally, problems of temporary disposal of spent nuclear fuel from commercial nuclear power plants could induce higher electricity rates. However, some utilities may not be able to store all spent nuclear fuel until Federal storage begins in 1998. These utilities could be forced to develop new storage pool facilities, transport the spent fuel to other sites, develop other storage techniques, seek temporary Federal storage, or cease operations altogether--all expensive alternatives.

These factors as well as others will almost certainly influence electricity markets over the 1985-1995 forecast period. Nevertheless, based on presently known trends, electricity markets should enjoy moderate growth over the next 10 years. 


\section{HISTORY OF THE U.S. ELECTRIC UTILITY INDUSTRY}

The history of the U.S. electric utility industry is one of rapid growth (Figure 1). Until recently, electricity demand growth consistently exceeded the rate of growth of Gross National Product (GNP). Electricity's growth rate from 1900 through 1980 was almost triple the rate of real GNP growth (Table 1). Its growth from 1900 through 1984 was almost uninterrupted, averaging almost 9 percent a year (Appendix B). Its expansion can be attributed to consumer prefer- ence for electricity over other forms of delivered energy and to its steadily dropping price over most of its history. Nevertheless, as recent years' price increases show, the industry appears to have undergone changes in its cost structure during the 1970's and 1980's.

This chapter traces the history of the U.S. electric utility industry and the development of its present structure.

\section{Figure 1. Net Generation by U.S. Electric Utilities, 1902-1984}

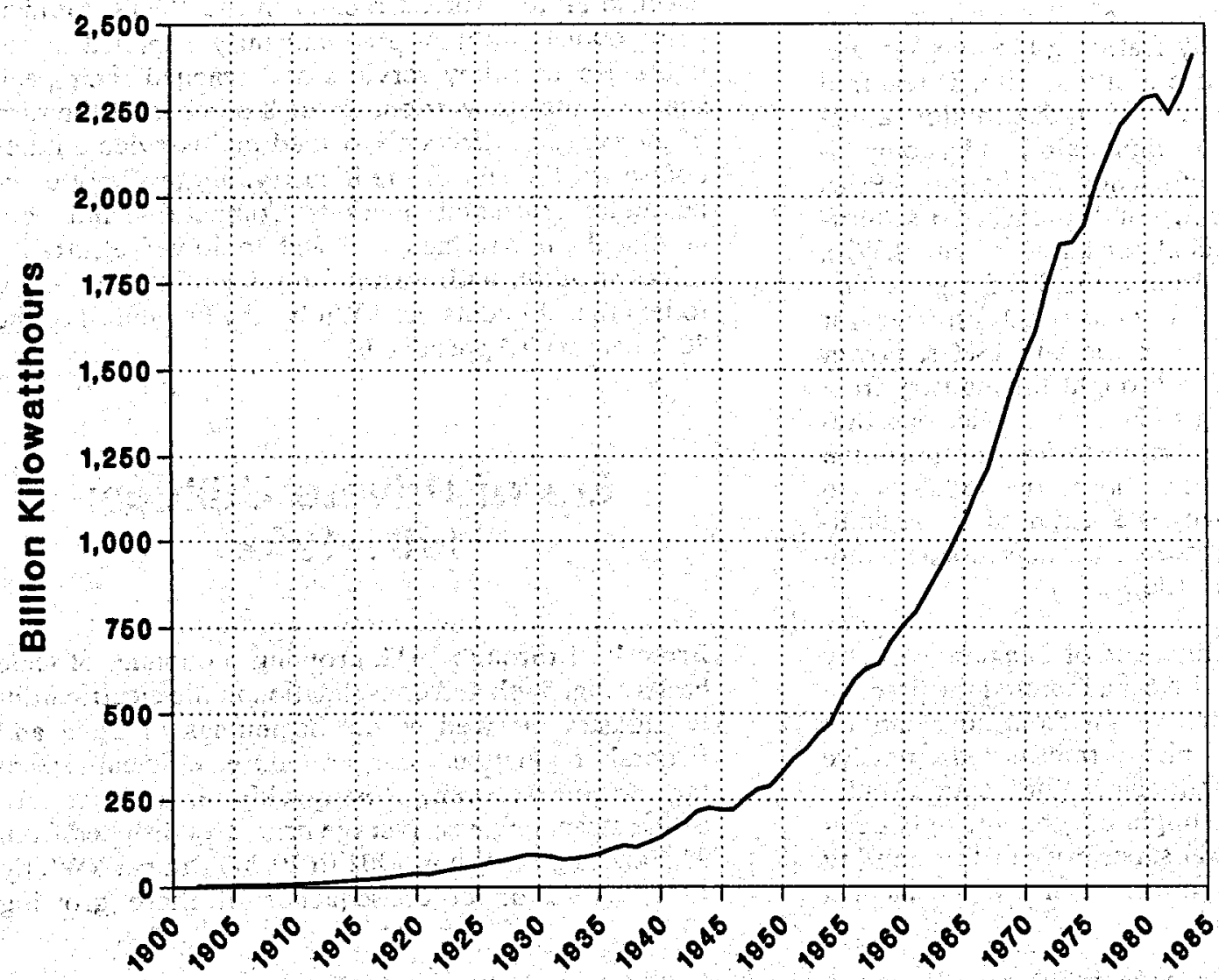

Sources: - 1902-1948: Edison Electric Institute, Historical Statistics of the Electric Utility Industry Through 1970 (1973), p. 24; - 1960-1984: Eneroy Information Administration, Annual Energy Review 1984 (April 1885), p. 171. 


\begin{tabular}{|c|c|c|c|c|c|c|c|c|c|c|}
\hline \multirow{2}{*}{\multicolumn{2}{|c|}{$\because \quad \begin{array}{l}\text { Initial } \\
\text { Year }\end{array}$}} & \multicolumn{4}{|c|}{$\therefore \therefore \quad \square \quad \square$} & \multicolumn{5}{|c|}{ Final Year } \\
\hline & & 1910 & 1920 & 1930 & 1940 & 1950 & 1960 & 1970 & 1980 & 1990 \\
\hline $\begin{array}{l}1900 \\
1910 \\
1920 \\
1930 \\
1940 \\
1950 \\
1960 \\
1970 \\
1980\end{array}$ & & 4.2 & $\begin{array}{r}5.7 \\
10.2\end{array}$ & $\begin{array}{l}4.8 \\
5.4 \\
3.0\end{array}$ & $\begin{array}{l}4.3 \\
4.5 \\
2.8 \\
2.4\end{array}$ & $\begin{array}{l}3.6 \\
3.4 \\
2.4 \\
2.1 \\
1.9\end{array}$ & $\begin{array}{l}3.4 \\
3.2 \\
2.5 \\
2.3 \\
2.2 \\
2.7\end{array}$ & $\begin{array}{l}3.2 \\
2.9 \\
2.3 \\
2.2 \\
2.1 \\
2.2 \\
1.9\end{array}$ & $\begin{array}{l}2.9 \\
2.7 \\
2.1 \\
2.0 \\
1.9 \\
1.9 \\
1.6 \\
1.3\end{array}$ & $\begin{array}{l}2.7 \\
2.5 \\
2.0 \\
1.8 \\
1.8 \\
1.7 \\
1.4 \\
1.1 \\
0.9\end{array}$ \\
\hline
\end{tabular}

Sources: Net Generation 1000-1980, Appendix B. Net generation for 1900 was assumed to be approximately 2 billion kilowatthours, and for 1910 , approximately 10 billion kilowatthours. Real Gross National Product: 1900-1980, U.S. Department of Commerce, Bureau of Economic Analysis, 1972. 100. Projected 1990 ratios are derived from these sources and from the Energy Information Administration, Annual Energy Outlook 1984 (Janiàn 1985).

\section{Beginnings: 1882-1900}

The modern electric utility industry began in the 1880 's. It evolved from gas and electric carbon-arc commercial and street lighting systems. Thomas Edison's Pearl Street electricity generating station, which opened September 4,1882, in New York City, introduced the industry by featuring the four key elements of a modern electric utility system. It featured reliable central generation, efficient distribution, a successful end use (in 1882, the light bulb), and a competitive price. A model of efficiency for its time, Pearl Street used one-third the fuel of its predecessors, burning about 10 pounds of coal per kilowatthour ( $\mathrm{kWh}$ ), a "heat rate" equivalent of about $138,000 \mathrm{Btu}$ per $\mathrm{kWh}$. Initially the Pearl Street utility served 59 customers for about 24 cents per $\mathrm{kWh} .^{6}$ In the late 1880 's, power demand for electric motors brought the industry from mainly nighttime lighting to 24-hour service and dramatically raised electricity demand for transportation and industry needs. By the end of the $1880^{\prime} \mathrm{s}$, small central stations dotted many U.S. cities; each was limited to a few blocks' area because of transmission inefficiencies of direct current (dc).

The hydroelectric development of Niagara Falls by George Westinghouse in 1896 inaugurated the practice of placing generating stations far from consumption centers. The Niagara plant transmitted massive amounts of power to Buffalo, New York, over 20 miles away. With Niagara, Westinghouse convincingly demonstrated both the general superiority of transmitting power with electricity rather than by mechanical means (the use of ropes, hydraulic pipes, or compressed air had also been proposed) and the transmission superiority at that time of alternating current (ac) over dc. Niagara set a contemporary standard for generator size, and was the first large system supplying electricity from one circuit for multiple end-uses (railway, lighting, power).

Electric utilities spread rapidly in the 1890's. Municipally owned utilities predominantly supplied street lighting and trolley services and reached their peak share of total generation, about 8 percent, at the turn of the century. ${ }^{7}$ Privately owned multiservice utilities controlled the rest of the industry, aggressively competing for central city markets. Competition and technological improvements served to lower electricity prices steadily, with nominal residential prices falling to less than 17 cents per $\mathrm{kWh}$ by the beginning of the 20th century (Appendix B).

\section{Era of Private Utilities: 1901-1932}

From 1901 through 1932, growing economies of scale hastened growth and consolidation in the electric utility industry, as well as the beginnings of State and Federal regulation. Larger, more efficient steam turbine-powered generators quickly replaced reciprocating steam engines; average heat rates dropped from 92,500 Btu per kWh in 1902 to 20,700 Btu per kWh by 1932. ${ }^{8}$ As a direct consequence of those growing

\footnotetext{
${ }^{5}$ Charles E. Neil, "Entering the Seventh Decade of Electric Power, Some Highlights in the History of Electrical Development," reprinted from Edison Electric Institute Bulletin (September 1942), p. 6.

${ }^{6}$ Abram John Foster, The Coming of the Electrical Age to the United States (New York: Arno Press, 1979), pp. 120, $123,181$.

${ }^{7}$ Edison Electric Institute, Historical Statistics of the Electric Utility Industry Through 1970 (New York, NY), p. 24.

${ }^{8}$ Charles E. Neil, "Entering the Seventh Decade of Electric Power," from Edison Electric Institute Bulletin (September 1942$)$, p. 6.
} 


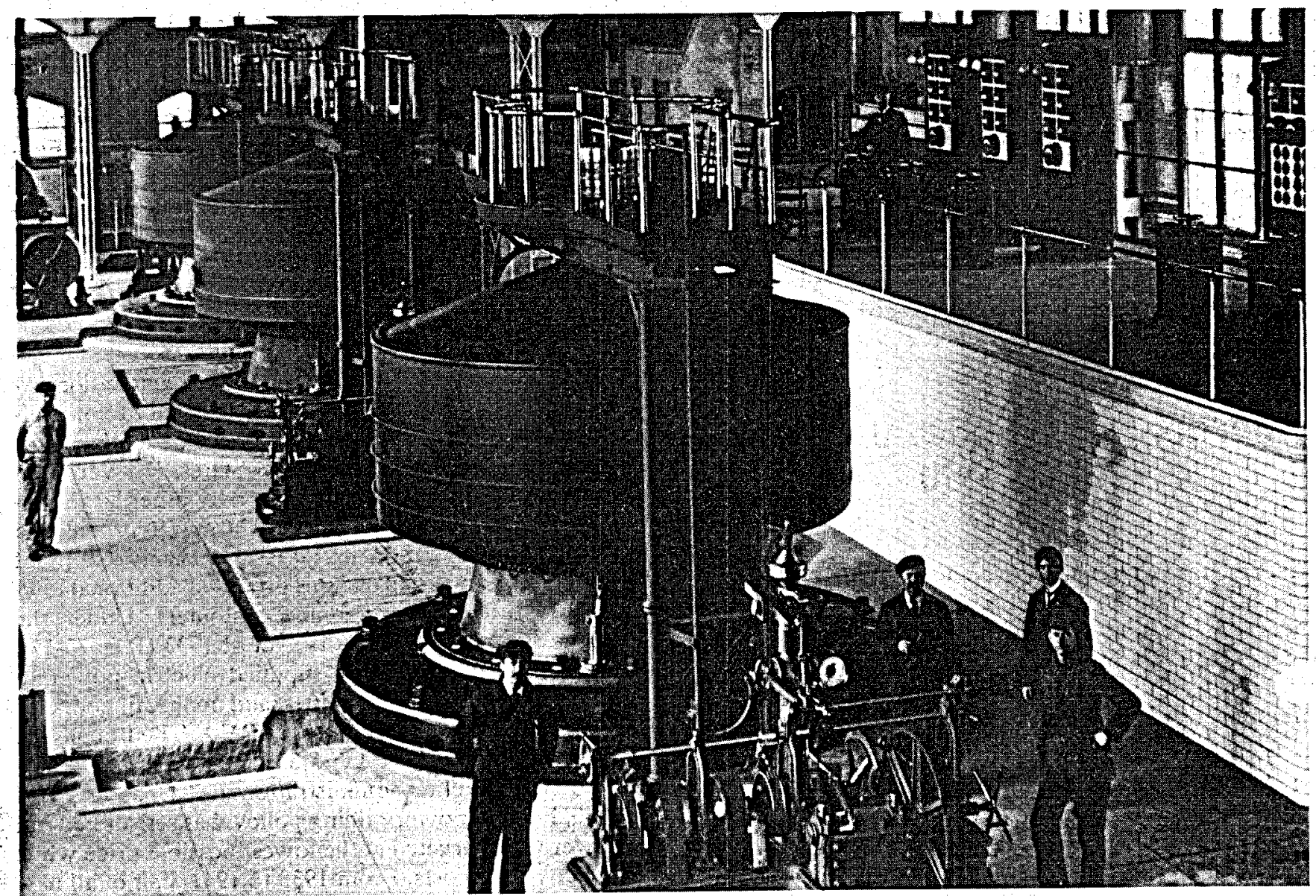

In 1895 Niagara's three 5,000 kilowatt hydroelectric generators set a new standard in generator size and efficiency.

efficiencies, small private and municipal lighting and railway or power companies either merged with, purchased electricity from, or were absorbed quickly by ever-larger, more efficient private multiservice systems. Systems and cities interconnected with high voltage transmission lines. Private electric utility ownership also consolidated into large utility holding companies, each "holding" controlling interest in a number of electric utilities. At their peak in the late 1920's, the 16 largest electric power holding companies controlled over 75 percent of all U.S. generation.

The growth of utility service areas, first beyond city boundaries and then across State lines, brought State regulation of electric utilities in the early 1900 's. Georgia, New York, and Wisconsin established State public service commissions in 1907 , followed quickly by more than 20 other States. Basic State powers included the authority to franchise the utilities, to regulate their rates, financing, and service, and to establish utility accounting systems.

The foundations for strong Federal involvement in the electricity industry were established between 1901 and 1932, based on three factors: first, the electric power industry became recognized as a natural monopoly in interstate commerce (producing a product most effi- ciently provided by one supplier) subject to Federal regulation; second, the Federal Government owned most of the Nation's hydroelectric resources; and third, Federal economic development programs accelerated, including electricity generation. In 1906, Congress authorized the sale of surplus Federal power from western irrigation projects, giving sale preference to municipalities. The Federal Water Power Act of 1920 (P.L. 66-280) codified Federal powers and established the Federal Power Commission (FPC) to issue hydroelectric development licenses revokable after 50 years. In 1928 Congress authorized the Boulder Canyon Project for irrigation, flood control, and electricity production.

From 1901 to 1932, electric utility capacity and generation grew at annual average rates of about 12 percent a year, despite a 14-percent absolute drop in generation from 1929 to the Depression-era low in 1932 (Appendix B). Both the number of municipal utilities and their share of total generation dropped steadily, as municipals were overwhelmed by larger, more efficient private systems. By 1932 municipals contributed only 5 percent of total generation. At the same time, Stateowned utilities and Federal systems, however, grew noticeably, together contributing over 1 percent of total generation. Private utilities provided the remain-

\footnotetext{
${ }^{9}$ Encyclopedia Americana, International Edition, Vol. 22 (New York: Americana Corporation, 1977), p. 769.
} 
ing 94 percent. ${ }^{10}$ Electricity prices dropped, with nominal residential electricity prices falling to 5.6 cents per kWh in 1932, a level about one-third their price at the beginning of the century (Appendix B). In 1907, only 8 percent of all dwellings were using electricity; by 1932 , this figure had risen to 67 percent. By 1932 considerably more than 80 percent of urban dwellings were electrified, while only 11 percent of farm dwellings had electrical service. This disparity between urban and rural service led to demands by farm interests for government help in obtaining electric power. ${ }^{11}$

\section{Emergence of Federal Power: 1933-1950}

The Federal Government became a regulator of private utilities in the 1930 's; it also became a major producer of electricity beginning in this period. The 1933-1950 period was also characterized by continued growth of the industry, increased consolidation and interconnection, and increasing economies of scale.

\section{$1933-1941$}

The Federal Government moved quickly in the mid1930 's to regulate private power and, where opportunities appeared, to produce and distribute less expensive Federally produced electricity to preference customers. Federal participation was hastened by widespread public perception of private utility abuses and national efforts to overcome the Depression.

First, the Federal Government moved to regulate private utilities. To counter utility abuses beyond State control, the Public Utility Holding Company Act of 1935 (PUHC, P.L. 74-333) provided for the regulation of utility holding companies by the Securities and Exchange Commission (SEC). The Federal Power Act of 1935 (Title II of PUHC) established FPC regulation of utilities involved in interstate wholesale transmission and sale of electric power.

Second, the Federal Government encouraged the growth of rural electricity service by subsidizing the formation of rural electric cooperatives. The Rural
Electrification Act of 1936 (P.L. 74-605) established the Rural Electrification Administration (REA) to provide loans and assistance to organizations providing electricity to rural areas and towns with populations under 2,500. REA-backed cooperatives enjoyed Federal power preferences plus lower property assessments; exemptions from Federal and State income taxes, and exemption from State and FPC regulation. As a result, by 1941 the proportion of farm homes electrified rose to 35 percent, more than three times that of 1932.12

Third, in the 1930's Federal electricity generation expanded, providing less expensive electricity to municipals and cooperatives. Large Bureau of Reclamation dams began serving the western States; Hoover Dam began generation in 1936, followed by other large projects. Grand Coulee, the Nation's largest hydroelectric dam, began operation in 1941. U.S. Army Corps of Engineers flood control dams provided additional lowpriced power for preference customers. Under the Tennessee Valley Authority Act of 1933 (P.L. 73-17), the Federal Government supplied electric power to States, counties, municipalities, and nonprofit cooperatives, soon including those of the REA. The Bonneville Project Act of 1937 (P.L. 75-329) pioneered the Federal power marketing administrations (see Chapter 2). By 1940, Federal power pricing policy was set; all Federal power was marketed at the lowest possible price while still covering costs. From 1933 to 1941, half of all new capacity was provided by Federal and other public power installations. By the end of 1941, public power contributed 12 percent of total utility generation, with Federal power alone contributing almost 7 percent. ${ }^{13}$

During the pre-World War II years, electricity generating systems continued to grow in size and efficiency. Maximum turbine sizes and pressures doubled, and steam temperatures increased; generator cooling by pressurized hydrogen was introduced, resulting in higher generator outputs. Average heat rates dropped to 18,600 Btu per $\mathrm{kWh}$ by $1941 .{ }^{14}$ Improvements in transformers, circuit breakers, protection and reclosing devices, and transmission and distribution systems also continued, increasing both the efficiency and the reliability of electric utility systems.

Electricity prices continued to decline. Nominal residential electricity prices fell to 3.73 cents per $\mathbf{k W h}$ in 1941, a drop of about one-third from 1932. Demand for electric power grew steadily from 1932 to 1941 ,

\footnotetext{
${ }^{10}$ Edison Electric Institute, Historical Statistics of the Electric Utility Industry Through 1970, p. 24.
}

${ }^{11}$ U.S. Bureau of the Census, Historical Statistics of the United States, Colonial Times to 1970, Bicentennial Edition, Part 2 (Washington, DC, 1975), p. 827.

${ }^{12}$ U.S. Bureau of the Census, Historical Statistics of the United States, p. 827.

${ }^{13}$ Edison Electric Institute, Historical Statistics of the Electric Utility Industry Through 1970, pp. 2, 24.

${ }^{14}$ Charles E. Neil, "Entering the Seventh Decade of Electric Power," from Edison Electric Institute Bulletin (September 1942$)$, p. 6. 


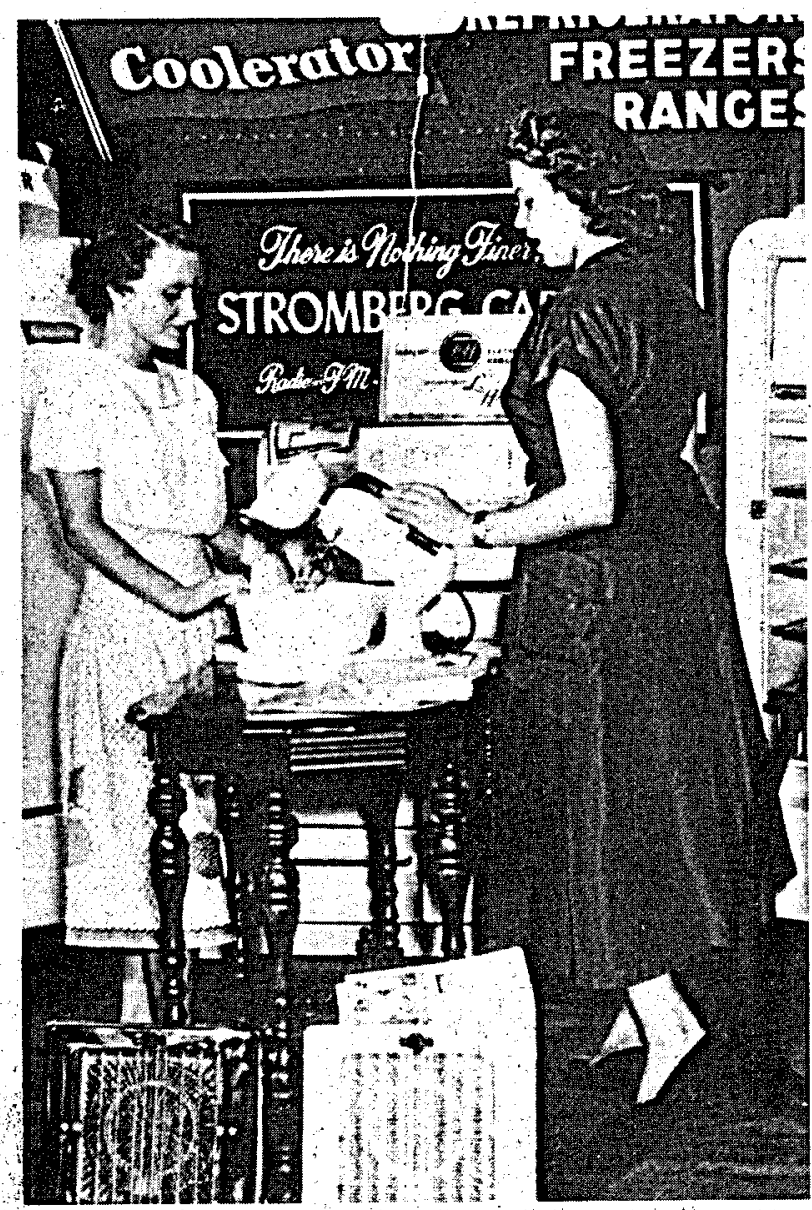

Electric appliance shows encouraged growth in household electricity use throughout the mid-20th Century.

with generation growth averaging over 8 percent a year, although capacity increased less than 2.5 percent per year (Appendix B).

is

\section{$1942-1950$}

Soaring electricity demand during World War II was met by increased use of privately owned capacity and a dramatic growth in Federal power. From 1941 to 1945, Federal capacity growth averaged 21 percent a year, and generation grew by 27 percent. By the war's end, Federal electricity generation had grown to over 12.5 percent of U.S. generation. ${ }^{\text {is }}$ Total U.S. generation grew at an annual average rate of over 7.5 percent during these war years, with capacity increasing at an annual average rate of almost 4.5 percent (Appendix B).

Both residential and commercial end use of electricity grew rapidly from 1941 to 1945 , despite the war. Almost one-half of all farm dwellings were electrified by 1945. Growth in demand was helped by continuing technological improvements, yielding overall heat rates below 16,000 Btu per $\mathrm{kWh}^{16}$ and residential electricity price drops averaging over 2 percent a year (Appendix B):

Public and Federal power continued to grow, and terms of public sale improved. Generating capacity built for defense was directed to public sale. The 1944 Pace Act (Department of Agriculture Organic Act, P.L. 78-425) extended REA indefinitely, dropped REA long-term interest rates below market rates, and authorized additional dam construction. The Flood Control Act of 1944 (P.L. 78-534) gave the Secretary of Interior jurisdiction over Corps of Engineers' electric power sales and extended public preference to all Corps power. The Southwestern Power Administration (SPA) and the Southeastern Power Administration (SEPA) were established in 1943 and 1950, respectively, to market Federal power to preference customers. The First Deficiency Appropriation Act of 1949 (P.L. 81-71) in effect authorized TVA construction of thermal-electric power plants for commercial electricity sale. By 1950, Federal generation contributed over 12 percent of total U.S. generation, while cooperatives and other public power provided almost 7 percent. ${ }^{17}$ In settling the Hope Natural Gas case (Federal Power Commission vs. Hope Natural Gas Company, 1944), the Supreme Court closed a longstanding dispute by allowing either original or replacement cost accounting in utility ratemaking, so long as just and reasonable rates result.

Following a brief decline at war's end in 1945, overall demand for electricity continued to grow. From 1945 through 1950, generation growth averaged over 8 percent a year and capacity over 6.5 percent (Appendix B). Residential electricity consumption grew most rapidly, almost 14 percent a year, and the share of farms electrified rose to almost 80 percent. ${ }^{18}$ Growth was encouraged by continued efficiency improvements; by 1950 heat rates had fallen below 15,000 Btu per $k W h .19$ Drops in nominal residential electricity prices averaged 3 percent a year (Appendix B).

\footnotetext{
${ }^{15}$ Edison Electric Institute, Historical Statistics of the Electric Utility Industry Through 1970, p. 24.

${ }^{16}$ Edison Electric Institute, EEI Pocketbook of Electric Utility Industry Statistics (New York, 1983), p. 21.

${ }^{17}$ Edison Electric Institute, Historical Statistics of the Electric Utility Industry Through 1970, p. 24.

${ }^{18}$ U.S. Bureau of the Census, Historical Statistics of the United States, pp. 827-828.

${ }^{19}$ Derived from Edison Electric Institute, EEI Pocketbook of Electric Utility Industry Statistics (1983), p. 21.
} 


\section{Utility Prosperity: 1951-1970}

The era following the end of World War II through 1970 marks a time of essentially uninterrupted prosperity for the electric utility industry. Demand for electricity grew rapidly, consistently, and predictably, while electricity prices continued to fall. The arrival of commercial nuclear power held the promise of an even more prosperous future. At the same time, problems that were later to affect the industry dramatically either did not exist or were not yet serious.

\section{The 1950's}

Three major characteristics mark the electric utility industry in the 1950's: robust growth, the introduction of commercial nuclear power, and other public power expansion replacing Federal power growth.

From 1950 to 1960 , generation grew by an average of over 8.5 percent a year, led by strong increases in residential electricity demand and near completion of rural electrification. Capacity grew slightly more rapidly than generation, averaging almost 9.5 percent annually.. With generating efficiencies still improving, electricity prices continued to decline, as evidenced by drops in nominal residential electricity prices averaging about 1 percent a year (Appendix B). ${ }^{20}$

Commercial nuclear power was introduced in the 1950's. The Atomic Energy Act of 1954 (P.L. 83-703) allowed private development of commercial nuclear power, and the Price-Anderson Act (P.L. 85-256) reduced private liability by guaranteeing public compensation in the event of a commercial nuclear catastrophe. The Nation's first central station commercial nuclear reactor, located in Shippingport, Pennsylvania, began operation in 1957.

Finally, during the 1950's new Federal power plant construction slowed, but the slowdown was offset by more rapid growth of other public power capacity. Both the "no new starts" policy of the Eisenhower Administration and a lack of additional major hydroelectric sites checked major new Federal development. Nevertheless, projects begun earlier continued to come on line, and Federal generation reached its highest share of total generation, over 17 percent, in 1957. TVA added thermal capacity, by 1960 becoming predominantly a thermal rather than hydroelectric system. Non-Federal public power grew rapidly in the 1950 's, led by cooperatives, power districts, and State projects. Generation from non-Federal public power plants and cooperatives increased from over 6.5 per-

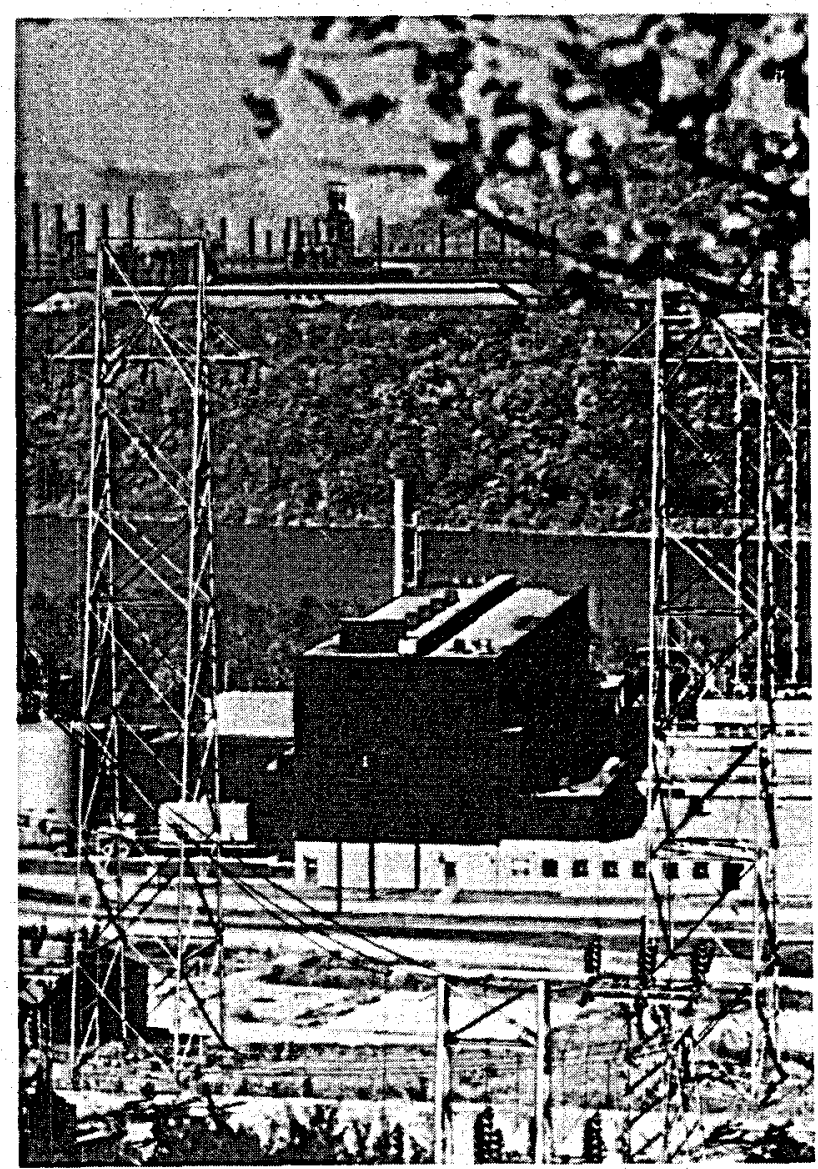

Shippingport, Pennsylvania, 1957-the Nation's first commercial nuclear power plant (100 megawatts)

cent of total generation in 1950 to almost 8.5 percent in 1960.21

\section{The 1960's}

During the 1960's high electricity growth rates continued, paralleled by growth in nuclear power generation. During the period, however, signs of future difficulties in the electric power industry appeared, including decreasing efficiency gains, escalating costs, and environmental concerns.

Vigorous growth continued throughout the 1960 's, prompted by overall economic growth, declining real energy prices, and growing consumer preference for electricity because of its convenience, versatility, and price. Generation and capacity growth averaged almost 7.5 percent a year (Appendix B), predominantly from increases in petroleum and gas-fired generation. Cooperatives accelerated capacity additions, and by 1970 non-Federal public power contributed well over

${ }^{20}$ Residential price declines for 1950 to 1960 are derived solely from Edison Electric Institute data. See footnote d, Appendix B.

${ }^{21}$ Edison Electric Institute, Historical Statistics of the Electric Utility Industry Through 1970, p. 24. 
10 percent of total utility generation. ${ }^{22}$ Demand grew nearly 7.5 percent a year, helped by annual declines of over 1.5 percent in residential and commercial electricity prices. ${ }^{23}$

New technology introduced during this period included automated controls and computers. Technological advances during the 1960's were led by the growth of commercial nuclear power. Facing continued high demand growth and encouraged by performance of small nuclear facilities, utilities began ordering many more nuclear units of far greater size and still undemonstrated efficiency. In contrast to the 837 megawatts (MW) of new capacity ordered in the 1950 's, with units averaging fewer than $150 \mathrm{MW}$, in the 1960 's, 86,596 MW were ordered, averaging about 850 MW per unit. ${ }^{24}$ Generation by nuclear power rose to over 1 percent of the U.S total by 1970.25

During the 1960 's some signs of difficulties in the electric utility industry began to appear. First, environmental requirements became a noticeable component of electric utility costs. Coal-fired power plants began to experiment with emission control equipment to decrease the amount of sulfur dioxide $\left(\mathrm{SO}_{2}\right)$ emitted into the atmosphere. Tall emission stacks were introduced to disperse $\mathrm{SO}_{2}$. Further, the National Environmental Policy Act of 1969 (NEPA, P.L. 91-190) required utilities seeking Federal permits for new power plants to prepare and defend environmental impact statements (EIS) as a part of the permit process. Second, the increasing efficiencies historically characterizing the industry flattened in the mid-1960's. From 1960 to 1970 , the average size of thermal plants more than doubled. Heat rates, on the other hand, declined only a little, from about $10,800 \mathrm{Btu}$ per $\mathrm{kWh}$ to $10,500 \mathrm{Btu}$ per $\mathrm{kWh} .{ }^{26}$ Finally a major Northeastern power blackout in 1965 raised concerns about the reliability of the huge interconnected, interdependent power networks; response to the blackout included formation of regional reliability councils, and the North American Electric Reliability Council (NERC) to promote the reliability and adequacy of bulk power supply (see Chapter 2, Electric Utility Organizations).

\section{Years of Challenge: 1971-1984}

\section{The 1970's}

During the 1970 's, the electric utility industry moved from decreasing unit costs and rapid growth to one of increasing unit costs and slowed growth. Among the major factors affecting the electric utility industry during the period were general inflation, increases in fossilfuel prices, environmental concerns, conservation, and problems in the nuclear power industry.

First, electric utilities with ambitious capital expansion programs heavily financed by borrowing were particularly affected by inflation. As technical and regulatory requirements increased construction lead times, the impact of inflation was compounded.

Second, in the 1970's all fossil-fuel prices rose sharply. Petroleum costs more than doubled in 1974 alone and increased an average of over 26 percent a year for the 1970-1980 period. Natural gas prices, accelerated by decontrol under the Natural Gas Policy Act (NGPA, P,L. 95-621), rose by over 23 percent a year, with the largest increases occurring after 1978. Coal price increases averaged almost 16 percent a year. ${ }^{27}$

Third, during the 1970's environmental legislation increased the costs of building and operating electric utility (particularly coal-fired) power plants. The Clean Air Act of 1970 (CAA, P.L. 91-604) and its amendments in 1977 (P.L. 95-95) required utilities to reduce pollutant emissions, particularly $\mathrm{SO}_{2}$, causing increases in capital, fuel, and operating costs. The Act also limited use of tall stacks to disperse emissions. The Federal Water Pollution Control Act of 1972 ("Clean Water Act," P.L. 92-500) limited utility waste discharges into water. In addition, the Resource Conservation and Recovery Act of 1976 (RCRA, P.L. 94-580) directed standards for disposal of both hazardous and nonhazardous utility wastes.

Finally, conservation legislation effectively barred utilities from wider use of natural gas and petroleum. The Energy Supply and Environmental Coordination

\footnotetext{
${ }^{22}$ Edison Electric Institute, Historical Statistics of the Electric Utility Industry Thnough 1970, p. 24.

${ }^{23}$ See Appendix B and Energy Information Administration, Annual Energy Review 1984, DOE/EIA-0384(84) (Washington, DC, April 1985),
} p. 187.

${ }^{24}$ Energy Information Administration, U.S. Commercial Nuclear Power, Historical Perspective, Current Status, and Outlook, DOE/EIA-0315 (Washington, DC, March 1982), p. 10.

${ }^{25}$ Energy Information Administration, Annual Energy Review 1984, p. 171.

${ }^{26}$ Energy Information Administration, Thermal-Electric Plant Construction Cost and Annual Production Expenses--1979. DOE/EIA-0323(79) (Washington, DC, May 1982), p. 10.

${ }^{27}$ Energy Information Administration, "Fuel Choice in Steam Electric Generation: A Retrospective Analysis," Volume 1, Overview, Draft Report, Table 2. 
Act of 1974 (ESECA, P.L. 93-319) allowed the Federal Government to prohibit electric utilities from burning natural gas or petroleum. The 1978 Powerplant and Industrial Fuel Use Act (FUA, P.L. 95-620) succeeded ESECA and extended Federal prohibition powers. The National Energy Conservation Policy Act of 1978 (NECPA, P.L. 95-619) required utilities to provide residential consumers free conservation services to encourage slower growth of electricity demand.

Expected high electricity demand growth did not materialize in the 1970 's. Instead, capacity growth began to outrun increases in demand. For the first time in the history of U.S. electric power, electricity prices rose consistently, with nominal price increases averaging 11 percent a year. Consequently, demand and generation growth moderated to just over 4 percent a year. However, capacity growth continued at a rate of 6 percent a year (Appendix B). Slackened demand growth, coupled with completion of expensive new capacity, left utilities with excess capacity and without new revenues to pay for it. As a result, some electric utilities suffered financial setbacks and incurred declining investor confidence.

The commercial nuclear power industry expanded rapidly but also met serious reverses. From 1971 through 1974,131 new nuclear units were ordered, at an average capacity of about $1,100 \mathrm{MW}^{28}$ Inflation and real labor and materials cost increases quickly affected construction costs of nuclear power plants, while high interest rates raised financing costs. Capital costs rose from about $\$ 150$ per $\mathrm{kWh}$ in 1971 to over $\$ 600$ after 1976. ${ }^{29}$ Utilities building commercial nuclear facilities faced financial difficulties in justifying and meeting these increased costs. Safety concerns increased. First, in February 1979 the Nuclear Regulatory Commission (NRC) shut down five operating reactors following concerns about durability during earthquakes. Then, on March 28, 1979, the Nation's most significant commercial nuclear accident occurred at the Three Mile Island Number 2 reactor near Harrisburg, Pennsylvania. These events heightened public concerns and spurred opposition to commercial nuclear power.

As a result of higher costs, slackening electricity demand growth, and public concern, demand for nuclear power plants dropped quickly in the mid- and late1970's. After 1974, new orders plummeted and cancellations accelerated. No new reactor orders were placed after 1978. Moreover, 63 units were canceled between 1975 and $1980 .{ }^{30}$

\section{The Early 1980's}

The early 1980's were marked by almost no growth in the U.S. electric utility industry. In 1982 total generation dropped more than 2 percent, the first absolute decline since 1945 (Appendix B). In the mid-1980's, however, the industry appears to have returned to moderate if unspectacular growth.

Cost and price increases continued to slow the growth of electric power in the early 1980's. Costs of new nuclear power plants increased to over $\$ 1,200$ per $\mathbf{k W}$ of capacity in the early 1980 's. ${ }^{31}$ High inflation ensured increases in other financial and operating costs. As a result, electricity prices rose sharply. Average end-use electricity prices (nominal) increased by almost 19 percent in 1980, 15 percent in 1981, and 12 percent in 1982 . End-use electricity consumption responded to rising prices and a sluggish economy by increasing only 1 percent in 1980 and 2.5 percent in 1981. Demand then dropped almost 3 percent in 1982, because of a decline in industrial electricity use of nearly 10 percent, as part of that year's severe economic downturn. ${ }^{32}$

However, other factors also slowed cost increases in the early 1980's. Growth in Federal fuel use restrictions slowed. The Omnibus Budget Reconciliation Act of 1981 (OBRA, P.L. 97-35) reduced Federal authority to issue oil- and natural gas-use prohibitions. Additional Clean Air Act amendments were considered but not enacted. Despite the accelerated decontrol of petroleum prices, worldwide oil surpluses in the early 1980's resulted in lower utility oil costs and provided some relief. Finally, while the recession of 1982 undoubtedly hurt electricity sales, it lowered the rate of overall inflation, resulting in lower interest rates and lowered rates of increase in other capital, operating, and maintenance costs.

Electricity generation increased in 1983 to a record high of 2,310 billion kilowatthours. Capacity, however, grew by little more than 1 percent over 1982, the smallest increase since 1956. Industrial electricity use grew most rapidly among end-use sectors, rebounding from its 1982 decline. The average price of electricity increased by 2.6 percent, less than the rate of inflation.

In 1984, electricity posted its largest single-year increase in generation since $1976,4.5$ percent. Though not large by historic standards, the growth rate reflected a healthy economy, generally increasing preference

${ }^{28}$ Energy Information Administration, U.S. Commercial Nuclear Power (March 1982), p. 10.

${ }^{29}$ Energy Information Administration, 1983 Survey of Nuclear Power Plant Construction Costs, DOE/EIA-0439(83) (Washington, DC, December 1983), p. 8.

${ }^{30}$ Energy Information Administration, U.S. Commercial Nuclear Power (March 1982), p. 10.

${ }^{31}$ Energy Information Administration, Survey of Nuclear Power Plant Construction Costs 1984, DOE/EIA-0439(84) (Washington, DC, November 1984), p. 15.

${ }^{32}$ Energy Information Administration, Annual Energy Review 1984, pp. 179, 187. 
for electricity, and a decline in electricity's price relative to other forms of energy. Capacity grew by 2.1 percent in 1984, led by coal-fired and nuclear-powered additions. Electricity prices increased at the rate of inflation, leaving real prices unchanged.

From 1980 through 1984, net electricity generation grew an average of a mere 1.4 percent annually. Gross National Product grew at twice that, yielding a GNP ratio of only 0.5 . End-use sales grew by only 2.1 percent a year, the slowest rate of growth since the early years of the Great Depression. Capacity, however, increased 2.3 percent a year, further raising reserves available to meet unexpected demand. Nuclear capacity additions entering commercial service, despite the absence of new orders, led the rate of new capacity growth, increasing by 6.1 percent a year. Prices rose by approximately 8 fercent a year. Commercial electricity use increased siore than any other end use, averaging almost 4.5 percent a year; industrial end use grew less than 1 percent a year. ${ }^{33}$ 
1 


\section{THE STRUCTURE OF THE U.S. ELECTRIC UTILITY INDUSTRY}

\section{Ownership Structure}

This chapter describes the ownership structure, regulation and interactions of the U.S. electric utility industry, and identifies the major organizations representing the industry.

In 1983 U.S. electric utility generating capacity totaled 658.2 gigawatts (million kilowatts), generating 2,310 billion kilowatthours $(\mathrm{kWh})$ of electricity. Ultimate consumers purchased 2,151 billion $\mathrm{kWh}$ at an average cost of 6.0 cents per $k W h$ (Tables 2 and 3). ${ }^{34}$ However, the distribution of capacity, generation, revenue, and sales differs widely among ownership groups. Furthermore, different types of ownership have different goals, organizational characteristics, and financing methods.
Economies of scale, capital availability, and social preference are three important factors in determining the form of ownership of an electricity producer or distributor. Private investor-owned utilities (IOU's) dominate the U.S. electric utility industry. Historically, IOU's have been most successful in serving large consolidated markets where generation economies-of-scale afforded the lowest prices. Federal, municipal, cooperative, and other publicly owned utilities played a secondary role. Where markets were too small for major economies-of-scale, the access of local governments or nonprofit organizations to government capital markets or to preference in purchase of less expensive Federal power allowed municipal, cooperative or other publicly owned utilities to predominate. Finally, in some instances social preference for economic reform, local control, conservation, or government or utility reform has led to public ownership of electric utilities.

Table 2. Selected U.S. Electric Utility Statistics, 1983

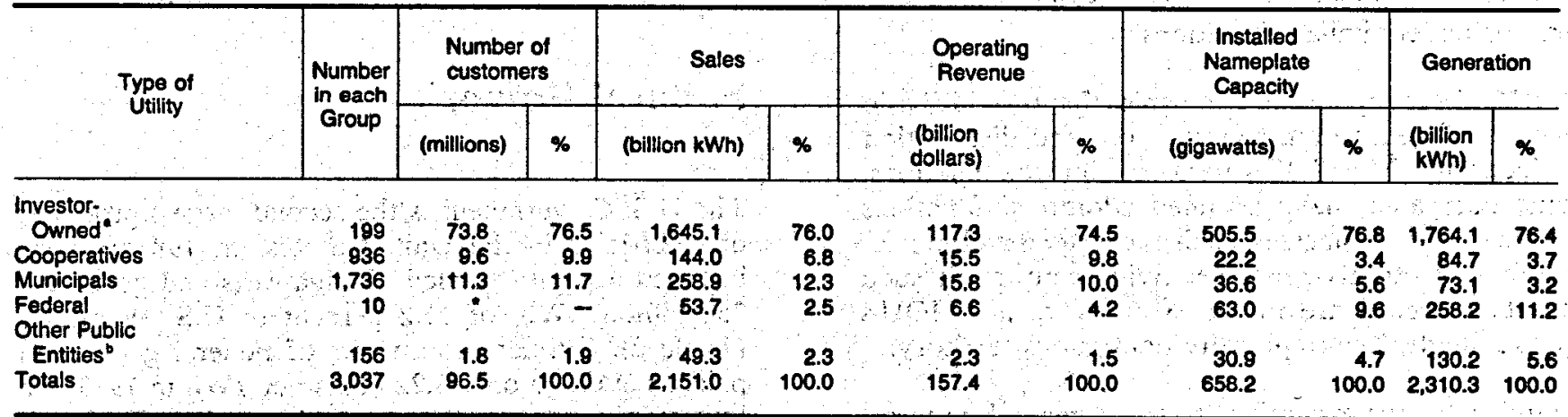

- Fewer than 50,000 customers.

Class $A$ and $B$ utilities only (those having annual operating revenues of $\$ 1$ million or more); these utilities are believed to provide over 90 percent of generation by investor-owned utilities.

- Other public entities include public power districts, State authorities, irrigation districts, and State organizations.

Note: Totals may not equal sum of components because of independent rounding.

Sources: Installed capacity and generation data, Edison Electric Institute, Statistical Yearbook of the Electric Utility Industry (1883).pp. 8, 20; Investor-owned utility data, Energy Information Administration, Financlai statistics of Selected Electric Utilitles 1983 (February 1985), pp. vit, 32;
-Cooperatives, municipals and other public entities data, Electrical World Directory of Electric Utilitles, McGraw-Hill Publications Co. (1984); Rural Electrification Administration, 1983 Statistical Report, Rural Electric Borrowers, Bulletin 1-1/Tennessee Valley Authority, Annual Report of the Tennessee Valley Authority, Volume It, 1983 (April 1984); Bonneville Power Administration, 1983 Program and Financlal Summary (March 1984); Southwestern Power Administration, 1983 Annual Report; Western Area Power Administration, 1983 Annual Report (March 1984); Alaska Power Administration, "Annual Report of Public Electric Utilities" (1983) Form ElA-412; Southeastern Power Administration, Annual Report 1983 (1984); unpublished data from the Bureau of Indian Affairs and the Western Area Power Administration.

${ }^{34}$ This chapter presents 1983 rather than 1984 data because sufficient 1984 data are not yet available. 


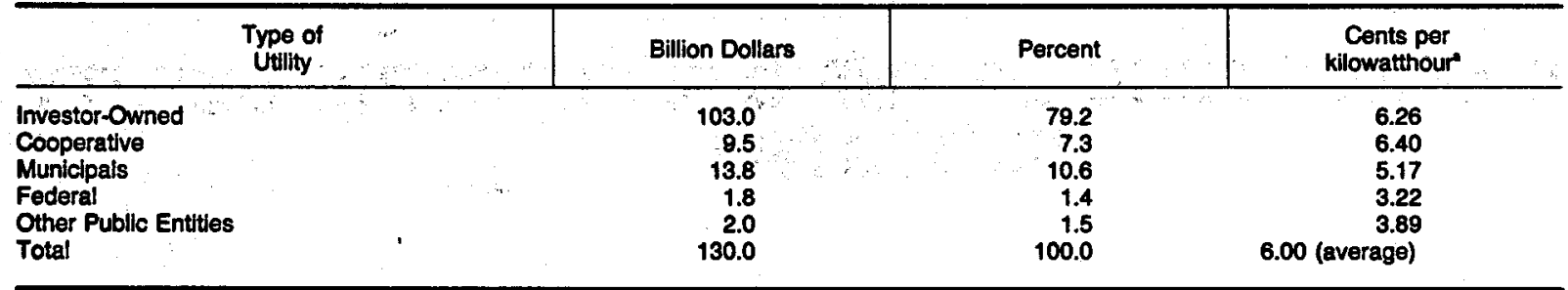

\footnotetext{
- Derived from revenue data in this table and energy sales data in Table 2.
}

Sources: Data for investor-owned utilities, Energy Information Administration, Financlal Statistics of Selected Electric Utilities 1883 (February 1985); All other data taken from or derived from Rural Electrification Administration, 1983 Statistical Report, Rural Electric Borrowers, Bullettn 1-1; Electrlcal World Directory of Electrlc Utlitles, 1984-1985, McGraw Hill Publications Co. (1.984); Publlc Power, JanuaryFebruary 1985; Tennessee Valley Authority, Annual Report of the Tennessee Valley Authority, Volume II, 1983 (1984); Bonneville Power Administration, 1983 Program and Flnanclal Summary (February 1984); Southwestern Power Administration, 1983 Annual Report; Western Area Power Administration, 1983 Annual Report; and unpublished data from the Bureau of Indian Affairs.

\section{Investor-Owned Utilities}

Investor-owned utilities (IOU's) account for about three-quarters of all U.S. electric utility capacity, generation, sales, and revenue. In 1983, these utilities, with an installed capacity of 506 gigawatts, generated 1.76 trillion $\mathrm{kWh}$ of electricity (Table 2). In 1983, ultimate consumers paid an average of 6.26 cents per $\mathrm{kWh}$ for privately produced power (Table 3 ).

IOU's are privately owned, profit-seeking businesses granted service monopolies in certain geographic areas with the obligation to serve all customers. Like all private businesses, the fundamental objective of a private utility is to produce a return for its investors. Indeed, management is subject to lawsuits from investors and stockholders if it fails to seek adequate profits. Nevertheless, as monopolies in the public interest, IOU's are required to charge reasonable prices (based on efficiently incurred costs), to charge similar prices to similar customers, and to give customers access to services under similar conditions.

MostIOU's are operating companies that provide basic services of generation, transmission, and distribution of electricity. Most IOU's perform all three functions. Some companies have assumed additional functions related to their businesses, such as energy development or other electricity-related activities, although such activities overall are minor. Moreover, most IOU's serve a single, geographically contiguous territory.

There are major exceptions to these general patterns. Holding companies are major utility businesses that do not generate, transmit, or distribute electricity; instead, they control (hold) groups of operating companies. As of mid-1983, 9 electric utilities were organized as holding companies under the Public Utility Holding Company Act of $1935,{ }^{35}$ and 60 other holding companies exempt from the Act also provided some electrical services. ${ }^{36}$

Most IOU's are organized as corporations. Furthermore, they are extremely capital-intensive. To finance their continued development, IOU's rely on internally generated funds, issue common and preferred stock, and sell long-term debt. Internally generated funds are composed of retained earnings, depreciation reserves, deferred taxes, and investment tax credits, of which depreciation reserves is the most significant. At the end of 1983, 41 percent of IOU's capital was attributable to common stock, 11 percent to preferred stock, and 48 percent to long-term debt (Table 2). ${ }^{37}$

IOU's operate in all States except Nebraska; Hawaii is the only State in which all electricity is supplied by private power companies.

\section{Federal Power}

The U.S. Government is the second largest producer of electricity in the United States. In 1983 Federal installed capacity totaled 63 gigawatts and generated 258 billion $\mathrm{kWh}$, or 11.2 percent of U.S. electricity (Table 2). Ultimate consumers of Federal generation paid on average only 3.22 cents per $\mathrm{kWh}$ in 1983 , the lowest rate among the ownership types (Table 3). Government-financed power (particularly hydroelectric) is primarily responsible for these low rates.

\footnotetext{
${ }^{35}$ Securities and Exchange Commission, Division of Corporate Regulation, Financial and Statistical Summary, Registered Public Utility Holding Company Systems (Washington, DC, December 21, 1982), p. 1.

${ }^{36}$ Energy Information Administration, Historical Financial Analysis of the Investor-Owned Electric Utility Industry, DOE/EIA-0443 (Washington, DC, February 1984); p. 13.

${ }^{37}$ Energy Information Administration, Financial Statistics of Selected Electric Utilities 1983, DOE/EIA-0437(83) (W'ashington, DC, February 1985), p. xvii.
} 
Table 4. Sources of Capital In the U.S. Electric Utility

Industry, by Ownership Type

\begin{tabular}{|c|c|c|c|c|c|c|}
\hline & $\begin{array}{l}\text { Capital } \\
\text { Type }\end{array}$ & $\begin{array}{l}\text { Investor- } \\
\text { Owned } \\
\text { Utilities }\end{array}$ & $\begin{array}{l}\text { Federal } \\
\text { Projects }\end{array}$ & $\begin{array}{l}\text { Rural } \\
\text { Electric } \\
\text { Coops. }\end{array}$ & Municipals & $\begin{array}{l}\text { Other } \\
\text { Public } \\
\text { Entities }\end{array}$ \\
\hline Debt capital & & $\begin{array}{l}\text { Capital } \\
\text { markets } \\
\text { Corporate } \\
\text { parent } \\
\text { Other }\end{array}$ & $\begin{array}{l}\text { FFB } \\
\text { Federal } \\
\text { approp. } \\
\vdots\end{array}$ & $\begin{array}{l}\text { REA } \\
\text { CFC } \\
\text { FFB } \\
\text { BFC }\end{array}$ & $\begin{array}{l}\text { Capital } \\
\text { markets }\end{array}$ & $\begin{array}{l}\text { Capital } \\
\text { markets }\end{array}$ \\
\hline Equity capital & & $\begin{array}{l}\text { Ratepayers } \\
\text { Investors }\end{array}$ & Ratepayers & $\begin{array}{l}\text { Ratepayers } \\
\text { Members }\end{array}$ & $\begin{array}{l}\text { Ratepayers } \\
\text { Governing } \\
\text { body }\end{array}$ & $\begin{array}{l}\text { Ratepayers } \\
\text { Governing } \\
\text { body }\end{array}$ \\
\hline
\end{tabular}

Note: REA $=$ Rural Electrification Administration.

CFC $=$ National Rural Utilities Cooperative Finance Corporation.

FFB Federal Financing Bank.

$B F C=$ Bank for Cooperatives.

Source: Lawrence J. Hill and Richard C. Tepel, "Regulation, Pricing, and Comparative Performance in the U.S. Electric Utility Industry by Ownership Typs," Oak Ridge National Leboratory, final draft report submitted to Energy Information Administration (September 1984).

In contrast to the IOU's, Federal power is not generated for profit. The goal of all Federal power producers is to provide power at the lowest possible cost consistent with sound business principles, giving preference to public bodies and cooperatives in the sale of electricity. Power production often occurs in support of or along with other Federal objectives such as irrigation, navigation, flood control, defense, or economic development. The Federal Government's first involvement with the electric power industry began with the sale of surplus power from western irrigation dams. Later, power was sold from multiple-use dams built to improve navigation or to control floods. The Tennessee Valley Authority (TVA), the largest Federal power producer, is also chartered to improve navigability, control floods, facilitate reforestation, serve the agricultural development of the Tennessee Valley, and support national defense.

The Federal Government is primarily a generator and wholesaler of electricity, rather than a distributor to ultimate consumers. In 1983, it sold only 21 percent of its generation, or 53.7 billion $\mathrm{kWh}$, to ultimate consumers (Table 2). These consumers include some large industrial customers, other Federal agencies, and customers of the Bureau of Indian Affairs. Most Federal generation is wholesaled to municipal electric utilities, cooperatives, and other nonprofit preference customers, as required by law (see Chapter 1). Although TVA is a wholesaler, it is responsible for meeting electric power demand in its area.

Federal electricity generation reaches consumers in 34 States. The power marketing administrations generally operate in all but the Northeast, upper Midwest, and Hawaii (Figure 2). Besides the special major Federal power organizations, the Alaska Power Administration operates its own dams and distributes power from them, and the Bureau of Indian Affairs operates dams and sells power to direct consumers. Also, the Department of Defense operates power plants for several of its installations scattered throughout the Nation. Four of the five power marketing administrations own transmission lines; only the Southeastern Power Administration owns none.

The power marketing administrations are part of the Department of Energy. The Bureau of Reclamation and the Bureau of Indian Affairs are part of the Department of Interior. The Army Corps of Engineers is part of the Defense Department. The TVA, however, is not part of a Federal department, but is instead a Government corporation reporting to the President.

While investor-owned utilities must compete for private capital, Federal power producers must compete for funds in the Federal budget process. The power marketing administrations are obligated to repay the capital costs, plus operating and maintenance costs invested by the Government in water projects, within 50 years. Bonneville and TVA may also issue bonds, Bonneville up to $\$ 3.75$ billion, ${ }^{38}$ and TVA up to $\$ 30$ billion. ${ }^{39}$

\section{Municipal Utilities}

Municipally owned electric utilities generate the least electricity but comprise the single most numerous ownership group. Municipals have the second-largest share of customers, sales; and operating revenues of the five ownership groups. In 1983 municipals generated 73 billion $\mathrm{kWh}$ and sold 259 billion $\mathrm{kWh}$ (Table 2). In 1983, 72 percent of municipals' sales were made up by purchases of Federal, private, and other public power.

\footnotetext{
${ }^{38}$ Bonneville Power Administration, 1984 Annual Report, DOE/BP-385 (February 1985), p. 40.

${ }^{39}$ Tennessee Valley Authority, 1984 Annual Report, Volume II, Appendices (March 1985), p. 11.
} 


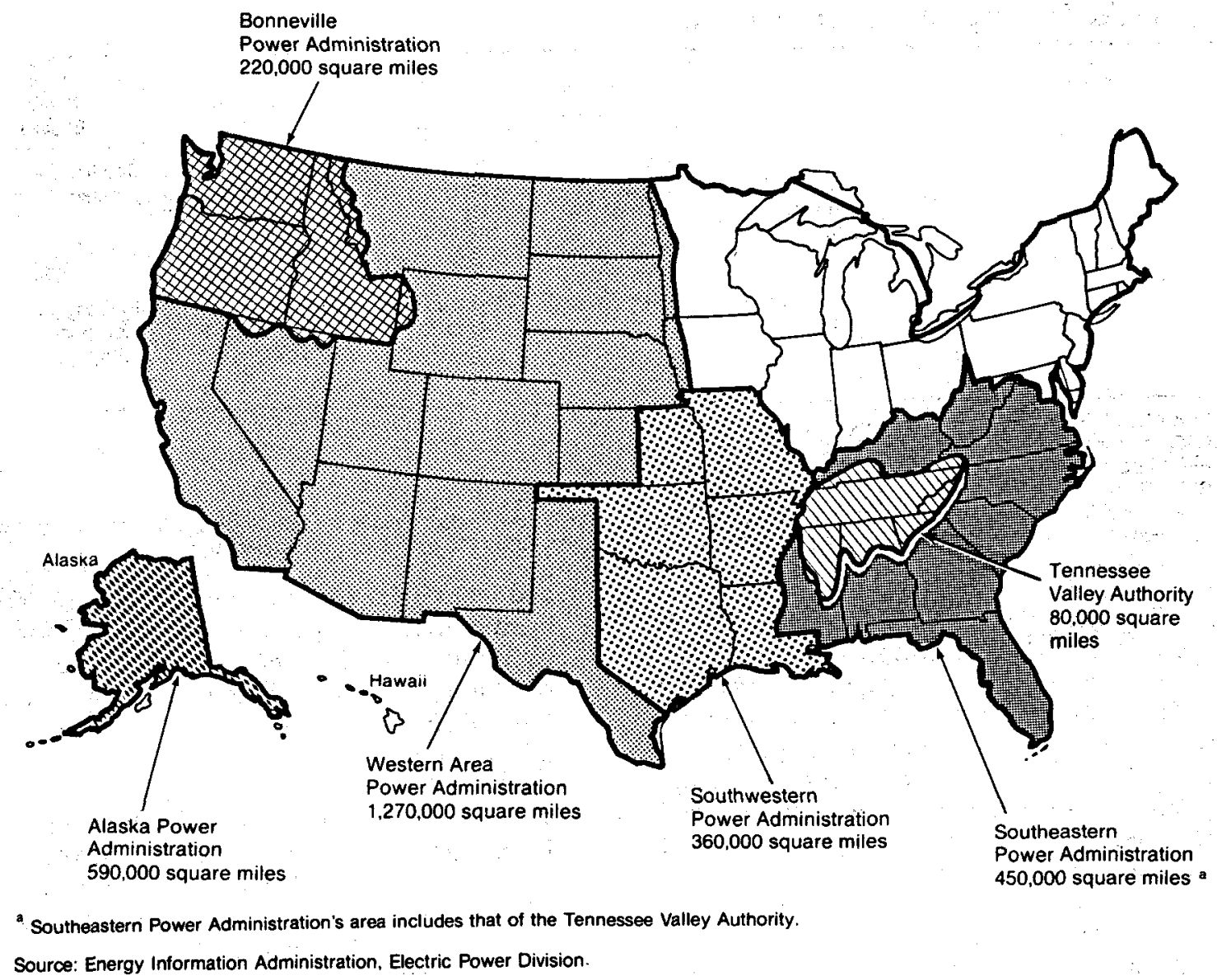

Average revenue per $\mathrm{kWh}$ sold in 1983 was 5.17 cents (Table 3), about 1 cent per $\mathrm{kWh}$ less than power from private utilities. This difference is the result of exemption from local, State, and Federal taxes, access to less expensive capital via public financing, access to less expensive Federal power, and no requirement to pay dividends.

Municipal electric utilities are nonprofit local government agencies established to serve their communities and nearby customers at the lowest possible cost. Most municipal utilities simply distribute power, although some larger ones generate, transmit, and distribute. More than half of the public utilities are under the direct control of a governing legislative body such as a city council. Most of the rest are under the control of an independent utility board. In recent years, municipal utilities have formed joint action agencies to exploit economies of scale in generation and transmission, making joint purchases, and exchanging power. More than 50 joint action agencies are in operation. ${ }^{40}$
Municipal electric utilities obtain their financing from municipal treasuries and from revenue bonds secured by proceeds from the sales of electricity. In 1983 about 68 percent of the capital in the largest municipal systems came from revenue bonds. ${ }^{41}$

Municipal utilities operate in all States except Hawaii (Figure 3). Three-fourths of municipal utilities operate in communities with populations of 10,000 or fewer persons. More than 60 percent of their sales occur in the Southeast and on the Pacific Coast, primarily because inexpensive Federal hydroelectric power is available in these areas. ${ }^{42}$

\section{Cooperatives}

Rural electric cooperatives rank third in number of customers, sales, and operating revenue (Table 2). In 1983 the cooperatives generated almost 85 billion $\mathrm{kWh}$,

\footnotetext{
${ }^{40}$ Lawrence J. Hill and Richard C. Tepel, "Regulation, Pricing, and Comparative Performance in the U.S. Electric Utility Industry by Ownership Type," Oak Ridge National Laboratory, draft report submitted to the Energy Information Administration (September 1984), p. 2-7.

${ }^{41}$ Energy Information Administration, Financial Statistics of Selected Electric Utilities 1983, p. 913.

${ }^{42}$ Lawrence J. Hill and Richard C. Tepel, “Regulation, Pricing, and Comparative Performance," p. 2-6.
} 
FIgure 3. Location of Municlpal and other Public Electric UtIlitles

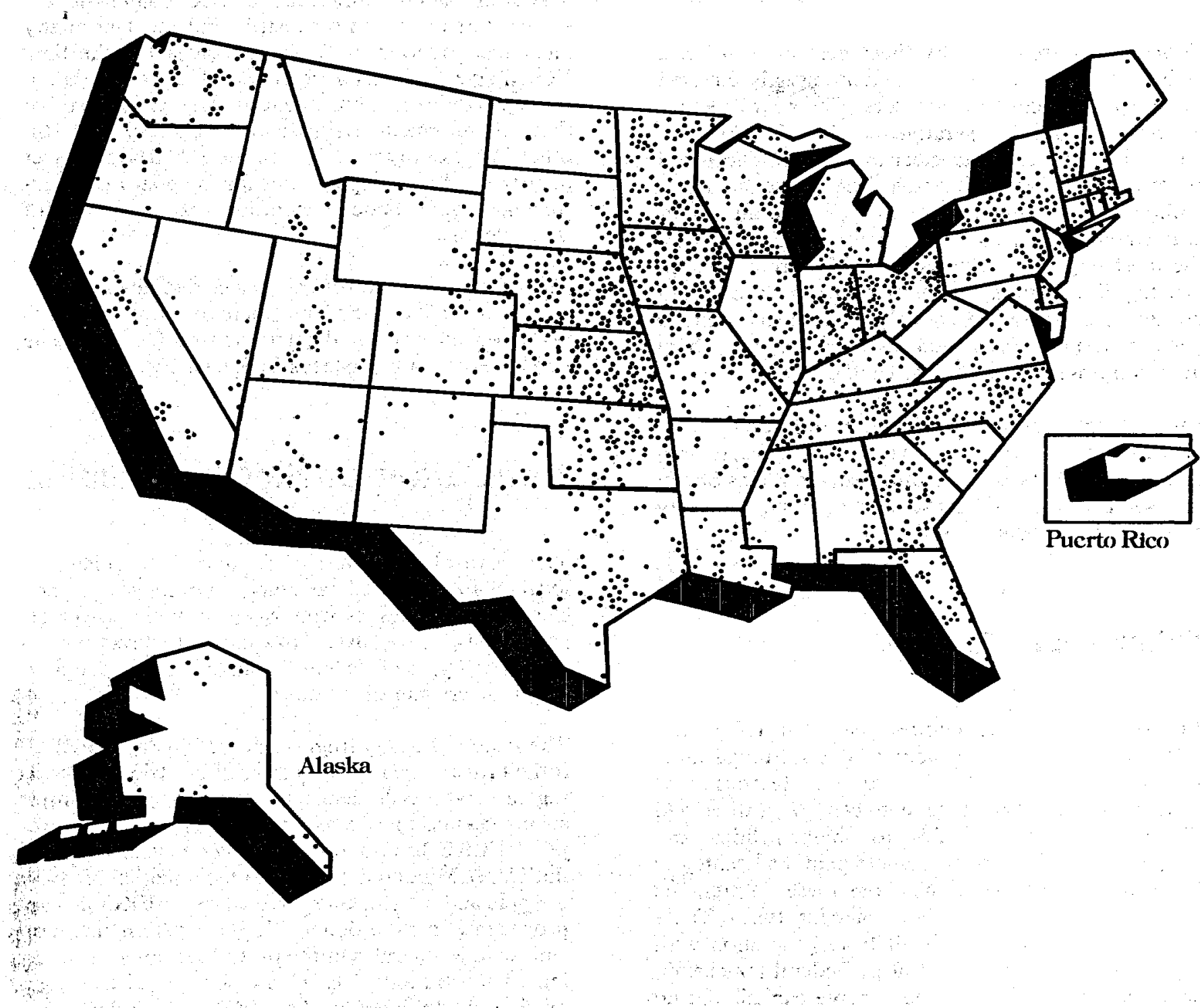

Source: American Public Power Association, The Public Benefits of Public Power (May 1984), pp. 6-7.

with an installed capacity of 22 gigawatts-the least installed capacity among the ownership categories. The cooperatives delivered 144 billion $\mathrm{kWh}$ of electricity to 9.6 million customers. Like the municipal utilities, the difference between sales and generation is made up by purchases from private companies, the Federal Government, or other public agencies. In 1983, cooperatives' average revenue from sales to ultimate consumers was 6.4 cents per $\mathrm{kWh}$, the highest of any of the five ownership types (Table 3 ). Higher rates resulted from the cooperatives' large construction programs of the 1970's.
Cooperatives are established to provide electricity to their members. The Rural Electrification Administration, which originally financed the cooperatives, was established to furnish electric energy to persons in rural areas who lacked electric utility service. Cooperatives are of two kinds: generation and transmission cooperatives and distribution cooperatives. There are currently 58 generation and transmission cooperatives, which are usually controlled by and provide electricity to 2 
or more distribution systems, and 878 distribution cooperatives. $^{43}$

Cooperatives are owned by their members. They are incorporated under State law and are usually directed by an elected board of directors. The board in turn selects a manager. Cooperatives conduct their business much the same as other electric utilities. The Rural Electrification Administration, the National Rural Utilities Cooperative Finance Corporation, the Federal Financing Bank, and the Bank for Cooperatives are the most important sources of cooperatives' debt financing. Distribution cooperatives rely more on mem. bership and patronage capital (34 percent) than do generation and transmission cooperatives, for whom debt comprises 96 percent of capital.4

Rural electric cooperatives are currently doing business in 46 States. Cooperatives in the Southeast, together with cooperatives in the Midwest, the Plains States, and Southwest, sell almost 90 percent of the electricity marketed by cooperatives. ${ }^{45}$

\section{Other Public Entities}

In 1983, other public entities generated 130 billion $\mathrm{kWh}$, with an installed capacity of almost 31 gigawatts, and sold over 49 billion $\mathrm{kWh}$ to ultimate consumers (Table 2). The difference between generation and direct sales was in sales to municipalities and cooperatives. Ultimate consumers paid 3.89 cents per kWh in 1983 for electricity from these entities, the second lowest of any of the ownership types (Table 3). Relatively low costs result from generation with inexpensive hydroelectric power, Federal tax exemptions, access to relatively inexpensive capital, and no requirement to pay dividends.

Other public entities include a variety of State or subsidiary ownership categories, including public power districts, State authorities, irrigation districts, and other State organizations. Public power districts and projects are concentrated in Nebraska (which has no private electric utilities), Washington, Oregon, Arizona, and California. Unlike cooperatives and municipal utilities, these entities may transcend rural and urban boundaries. About half of the other public entities only distribute electricity. About a fourth only generate and transmit power. The remaining fourth generate, transmit, and distribute power. ${ }^{46}$
Other public entities are governed in a variety of ways. Voters in a public utility district elect commissioners or directors to govern the district, independent of any municipal government. State authorities, like the New York Power Authority or the South Carolina Public Service Authority, are agencies of their respective State Governments. Irrigation districts may have still other forms of organization. In the Salt River Project in Arizona, for example, votes for the board of directors are apportioned according to the size of landholdings.

The capital structure of the power districts and projects is much like that of the municipal utilities; financing is obtained from the treasury or from revenue bonds secured by proceeds of electricity sales.

\section{Regulation of Electric Utilities}

The electric utility business is directly regulated at local, State, and Federal levels. All investor-owned electric companies, as well as some public power organizations, are regulated. In addition to direct regulation, other types of Federal regulation also affect power producers and distributors.

The Federal Energy Regulatory Commission (FERC) is the primary Federal regulator of electric utilities. It regulates wholesale electricity rates and power transfer arrangements, and licenses private hydroelectric projects (FERC has no authority over Federal dams or the TVA). Minor functions include regulation of utility mergers and interlocking directorates. FERC also approves rates for the Bonneville Power Administration and reviews the rates of the other four power marketing administrations. FERC is composed of five commissioners appointed by the President with the advice and consent of the Senate. The President appoints one member as chairman. All commissioners serve 4-year terms.

At the State level, public service commissions, public utility commissions, or similarly named bodies regulate utilities. While Federal regulation is significant, the States have the primary role in electric utility regulation. States regulate rates, service, safety, and construction or abandonment of plants. Although public utility commissions are primarily concerned with regulation of private utilities, some also have jurisdiction over municipal utilities and cooperatives. Utility commissions have from one to seven members, and terms in

\footnotetext{
${ }^{43}$ Rural Electrification Administration, 1983 Statistical Report, Rural Electric Borrowers, Bulletin 1-1, Table 3, p. xiii; Electrical World Directory of Electric Utilities, 1984-1985 (New York: McGraw-Hill, 1984).

${ }^{44}$ Rural Electrification Administration, 1983 Statistical Report, Bulletin 1-1, Table 22, p. xxix.

${ }^{45}$ Lawrence J. Hill and Richard C. Tepel, "Regulation, Pricing, and Comparative Performance," pp. 2-10 and 2-11.

${ }^{46}$ Edison Electrical Institute, Evolution of the Various Ownership Segments of the Electric Power Industry (New York, NY, 1973 ), p. 2.
} 
office vary from 4 to 10 years. Commissioners are usually appointed by the Governor with the approval of the State legislature, but in 11 States commissioners are elected. States and cities also regulate utilities through grants of franchise, either for a fixed time or in perpetuity.

Electric utilities may also face regulation from the Nuclear Regulatory Commission, Environmental Protection Agency, Department of Labor, Occupational Health and Safety Administration, Internal Revenue Service, Securities and Exchange Commission, and other State and local licensing and regulatory bodies.

\section{Interaction Among Utilities}

Cooperation among utilities occurs in sales of bulk power, power pools, wheeling, and joint projects. Bulk power transactions are wholesale purchases of power from other utilities. Through bulk power transactions, utilities try to cut costs by substituting lower cost purchases from other utilities for electricity from their own higher cost plants. Transactions also allow utilities mutual support in the face of high demand or equipment failure. A power pool is an agreement by two or more utilities to coordinate their power generation. Power pools range from informal agreements (loose pools) to systems with coordinated planning and centralized dispatching (tight pools). Eight loose and four tight power pools exist, representing about 45 percent of U.S. generating capacity. 47

Wheeling is the movement of electricity from one utility to another over transmission facilities of intervening utilities. Wheeling arrangements can be established between two utilities or among several; they normally require contracts among the utilities involved. In 1984 about 750 wheeling arrangements were on file at FERC. ${ }^{48}$ Joint projects by several utilities are another form of cooperation, particularly the joint construction of power plants. In 1965 only 5 plants were jointly owned; in 1970, 15; in 1980,60; and now more than 90 power plants are jointly owned. 49

Traditionally, utilities have competed for markets, for access to transmission lines, and for investors. Public and private utilities are currently contesting municipal preference in relicensing existing hydroelectric plants on navigable rivers. Older private 50 -year licenses issued by the Federal Power Commission, predecessor of FERC, are now expiring. Private utilities are seeking renewal of these licenses, but are being challenged by public utilities claiming preference in the relicensing process.

\section{Electric Utility Organizations}

Six organizations serve different aspects of the electric utility industry: the American Public Power Association, the Edison Electric Institute, the Electric Power Research Institute, the National Association of Regulatory Utility Commissioners, the National Rural Electric Cooperative Association, and the North American Electric Reliability Council.

The American Public Power Association (APPA) was founded in 1940. It represents more than 1,750 municipal and other local public power systems. APPA services include lobbying; research, training, insurance, a weekly newsletter and a bimonthly journal, and several specialized newsletters.

The Edison Electric Institute (EEI) is an association of 180 investor-owned electric utilities, organized in 1933 to succeed the National Electric Light Association. EEI acts as the spokesperson for investor-owned electric utilities, lobbies, does policy research, works with government agencies, prepares advertising and promotional materials, and produces a quarterly journal, statistical publications, and a variety of specialized reports for its members.

Since 1972, more than 600 public and private electric utilities have voluntarily funded the Electric Power Research Institute (EPRI) to research and develop both new and existing utility technologies to make them commercially viable. EPRI publishes a journal 10 times a year, and a variety of technical reports.

The National Association of Regulatory Utility Commissioners (NARUC), founded in 1889, is composed of government agencies engaged in utility and transportation regulation. NARUC aims to improve the quality and effectiveness of regulation. Although several Federal agencies are members, NARUC's primary interest is in representing State-level regulators. The Association publishes a weekly newsletter.

The National Rural Electric Cooperative Association (NRECA), organized in 1942, provides services for more than 1,000 members, including lobbying, consulting, training, insurance, and pensions. NRECA publishes a weekly newsletter and a monthly magazine and provides a news service for its State associations.

${ }^{47}$ Federal Energy Regulatory Commission, Power Pooling in the United States, FERC-0049 (Washington, DC, December 1981 ), p. 9.

${ }^{48}$ Lawrence J. Hill and Richard C. Tepel, "Regulation, Pricing, and Comparative Performance," p. 3-8.

${ }^{49}$ Federal Energy Regulatory Commission, Power Pooling in the United States, p. 10; Energy Information Administration, Inventory of Power Plants in the United States, 1981 Annual, DOE/EIA-0095(81), Table 8; 1982 Annual, Table 11; 1983 Annual, Table 17. 


\section{EPRI}

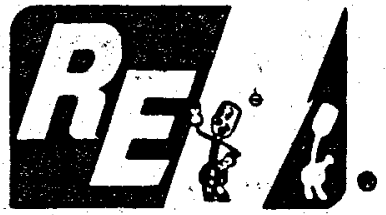

\section{EDISON ELECTRIC INSTITUTE}
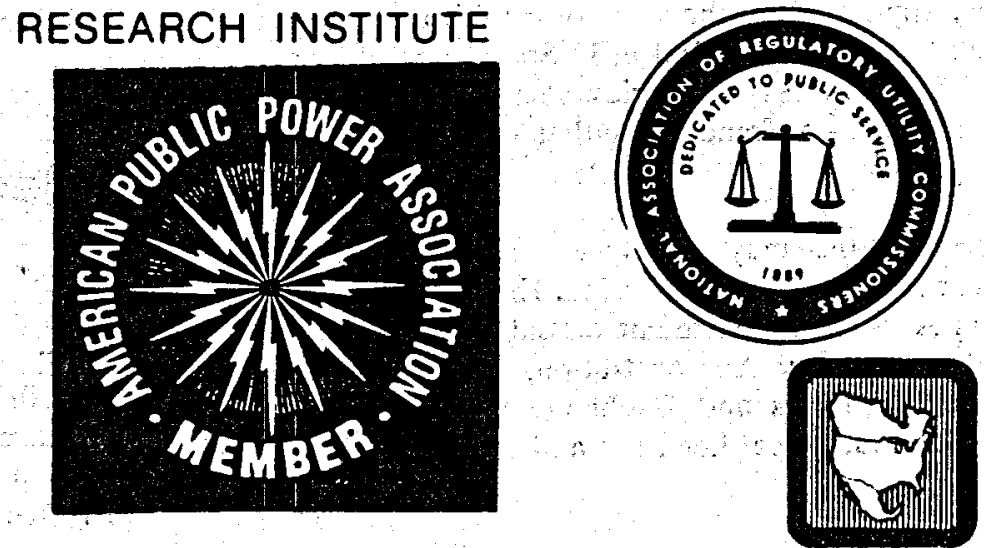

NORTH AMERICAN ELECTRIC RELIABILITY COUNCIL

Electric utility industry organizations

The North American Electric Reliability Council (NERC) was formed in 1968 to promote the adequacy of the bulk power supply throughout the continent and to promote the reliability of the electric system. NERC has nine regional councils (Figure 4), comprising nearly all the electric utility systems in the continental United States and Canada.

Figure 4. North American Electric Reliability Council Reglons

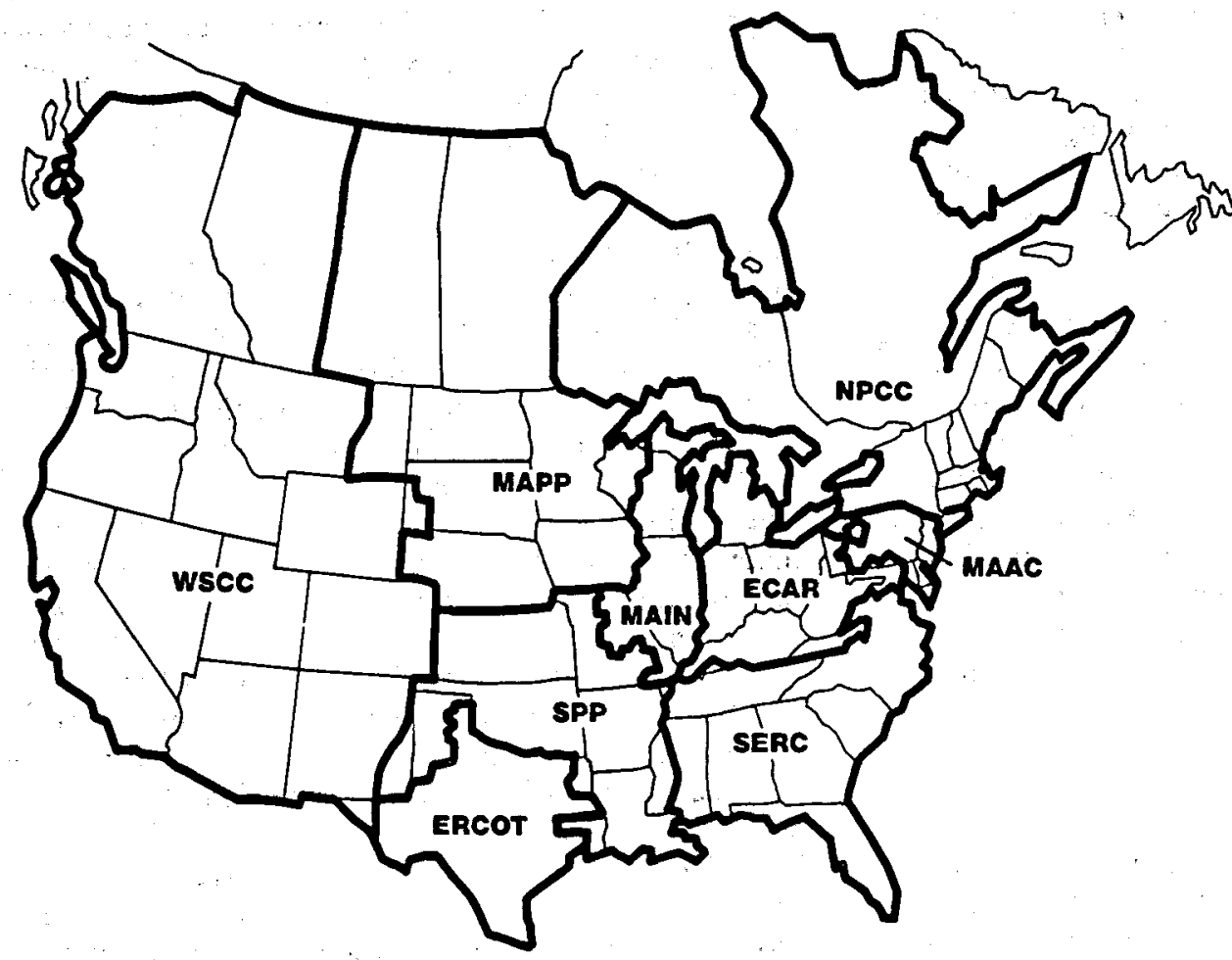

ECAR

East Central Area Reliability Coordination Agreement ERcoT

Electric Reliability Council of Texas MAAC

Mid-Atlantic Area Council

MAIN

Mid-America Interpool Network

MAPP

Mid-continent Area Power Pool

NPCC

Northeast Power Coordinating Council

\section{SERC}

Southeastern Electric Reliábility Council SpP

Southwest Power Pool

wsce

Western Systems Coordinating Council

AFFILIATE

ASCC

Alaska Systems Coordinating Council

Source: North American Electric Reliability Council. 


\section{OPERATIONAL OVERVIEW OF ELECTRIC UTILITIES}

\section{Introduction}

An electric utility system is a group of generation and transmission facilities, which are integrated to provide electricity to meet customers' requirements (Figure 5). It must meet all these demands at every moment with an uninterrupted flow of electricity. Because electricity' is generated and consumed instantaneously, a utility plans to meet the highest instant rate of usage by all its customers and still retain additional reserve capacity to handle the unexpected.

The electric utility industry operates under Federal and State regulatory bodies authorized to approve utility services and charges. Customer services provided by an electric utility must be available for all in a utility's service territory, and at a justifiable cost. Charges for these services are covered by rate schedules filed by each utility that take into account the cost of providing electricity to all its customers.

This chapter explores the interaction between the customers of an integrated electric utility system governed by this legal framework and the important operating segments of this industry--the generation and dispatching of electricity, and the control of an electrical system. It also discusses the transmission of electricity and why interutility transactions occur.

\section{Customer Requirements.}

Consumers expect electricity to be available whenever they plug in an appliance, turn a switch, or open a refrigerator. The electric utilities, on the other hand, understand that the customers determine the type and amount of services required. They are very aware of customers' expectations and of their obligation to provide service for both current and future customers in their service territories.

\section{Classes of Customers}

Customers within a utility's service territory are generally grouped into class-of-service categories such as residential, commercial, industrial, governmental, railway, and other classes as defined by the pertinent regulatory agency and/or utility. Utility service territories are geographically distinct and are usually composed of many different combinations of customer classes.

Customers are classified according to the amount of electricity they consume, the delivery voltage and rate, any special utility equipment needed in the delivery, end-use applications, and other social or economic characteristics. These classifications allow grouping of particular requirements for the convenience of the customers, the utilities, and the regulators.

Each class is generally distinguished by its parallel usage of similar services and by similar hourly patterns of usage. Other customer classes may have quite different needs for service over the day. Patterns of usage in adjacent service territories may also differ. On some occasions, one or more customer classes will experience their greatest need for electricity service, called peak load, at the same time. This peak load may come at different times of the day, at particular seasons of the year, and from various locations within the service territory. ${ }^{50}$ Sometimes peak loads occur simultaneously with the peak loads of adjacent utility service territories.

\section{Types of Service}

Electric utilities offer two major types of service to fulfill customers' needs. The first is continuous firm service, or "full requirements" service, where the utility is required to meet all customer needs. The second, called "partial requirements" service, is service that the utility may interrupt. Electric utilities price these categories differently in order to modify customer

\footnotetext{
30The convergence of peak load requirements has an even greater impact on utility planning if the customer classes have similar seasonal patterns of demand. Differing patterns of demand may be advantageous to the utility and are taken into account in planning the amount of expected capacity needed to serve its current and future customers.
} 
Flgure 5. An Integrated Electric UtIlity System

4

Generation
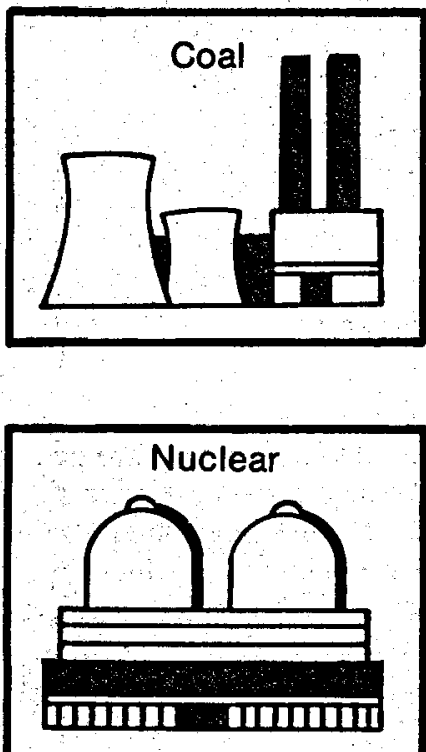

1
Dispatching and Control

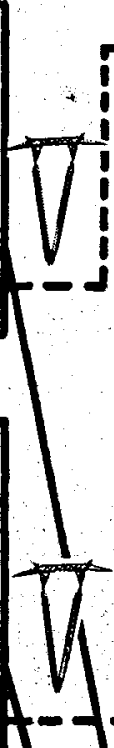

pr-0=-9

i ir $=-1$

i'

îi

in

111

!!

ili

III

lit!

ifi

111

(II)
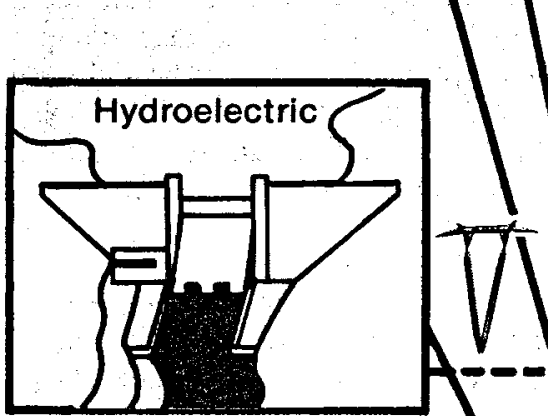

iil

II

ili

111

$1 !$
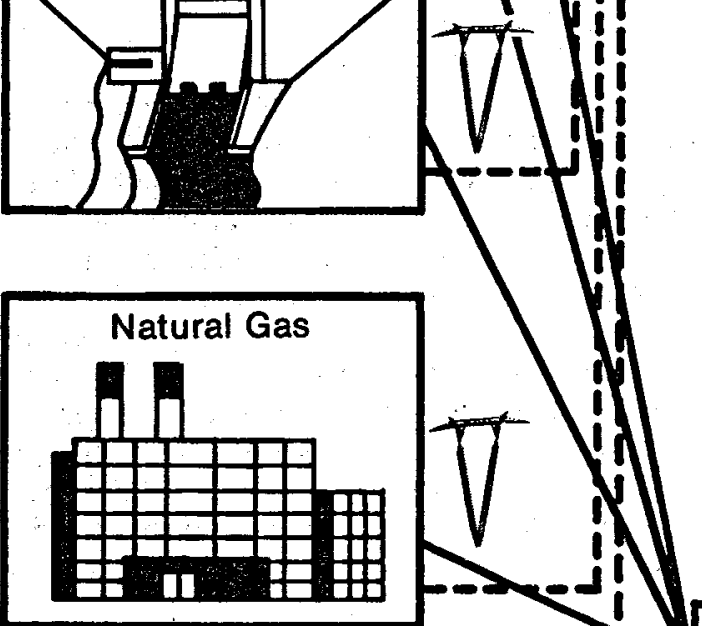

1
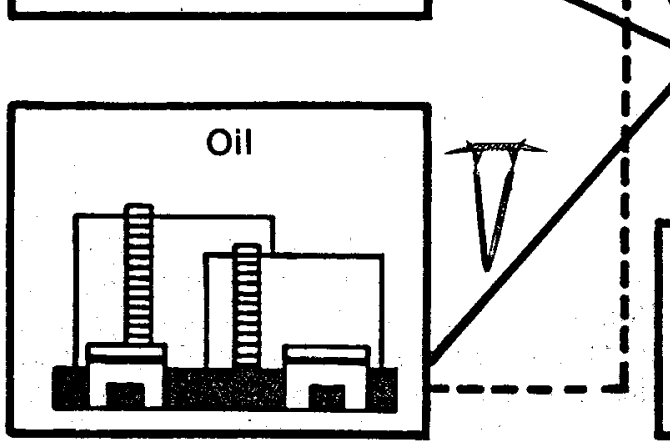

Tran

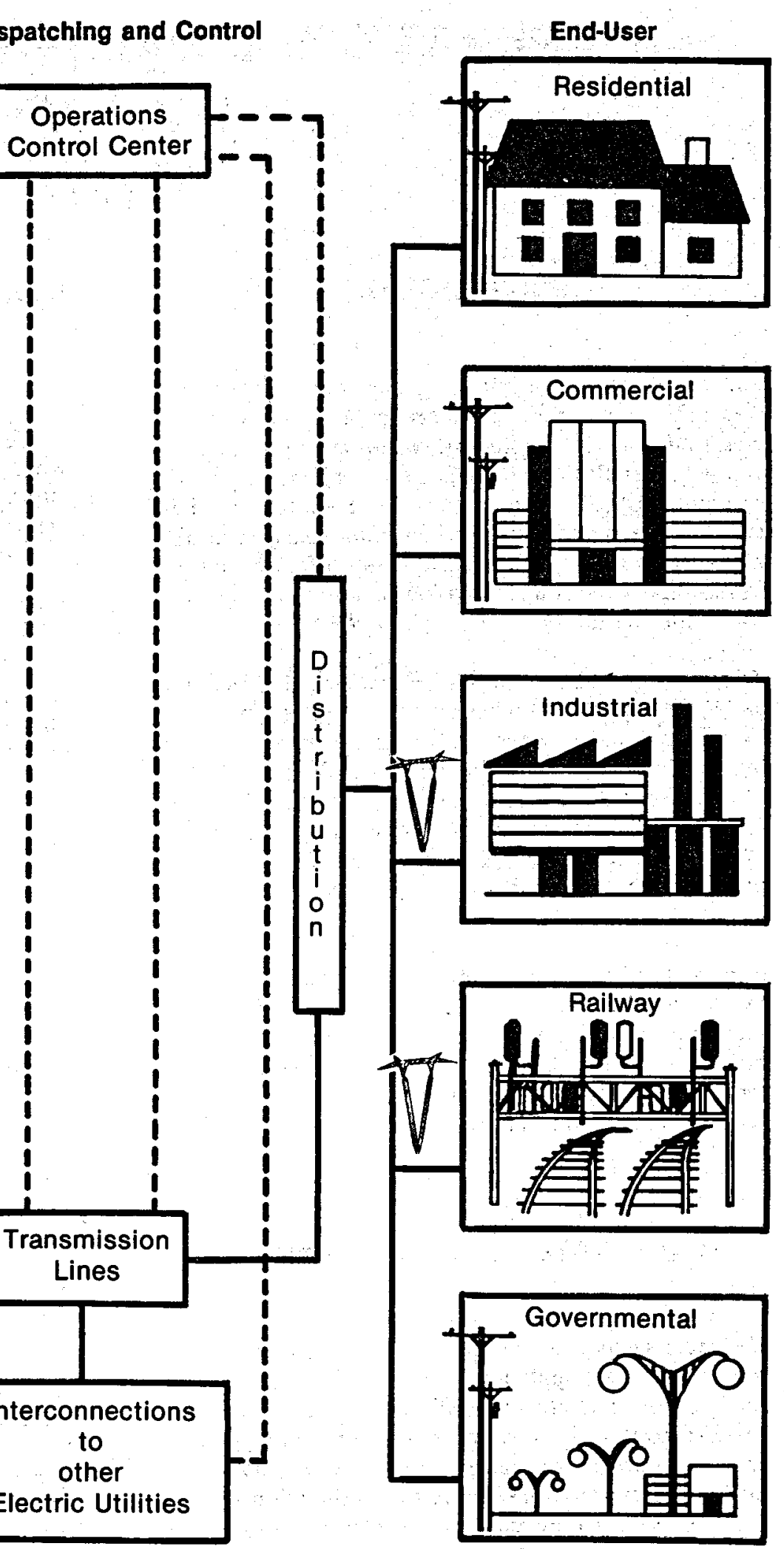

Lines
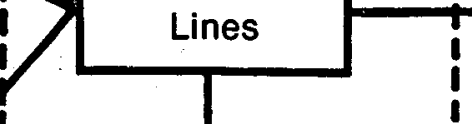

Interconnections

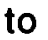

other

Electric Utilities

Source: Energy Information Administration, Electric Power Division.
Communication Lines

Transmission Lines 


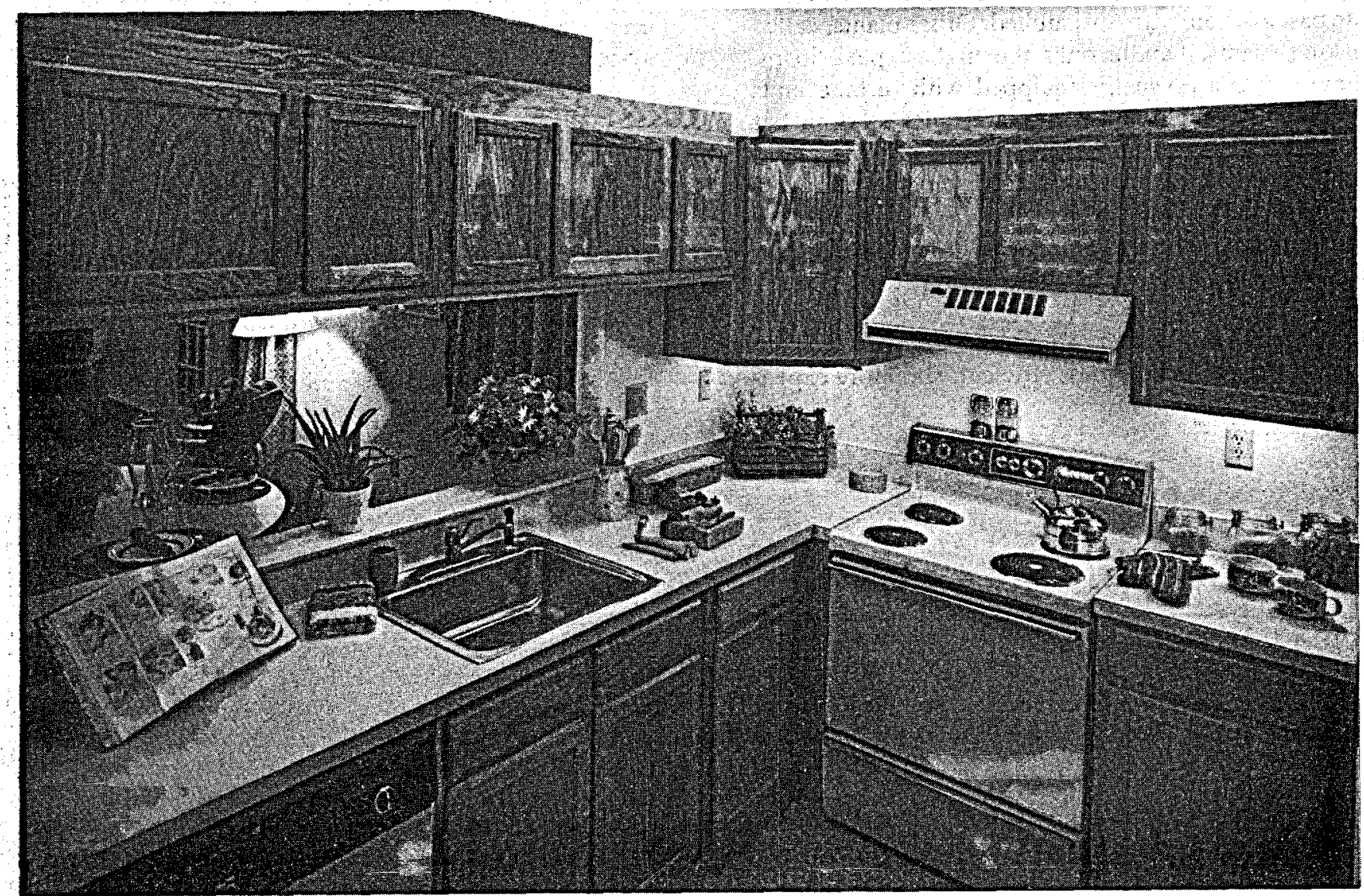

This kitchen illustrates labor-saving uses of electricity in the home.

demands, which helps the utility avoid expensive construction of additional capacity.

Many customers select interruptible service because it is less expensive than continuous firm service. If the total demand placed on a utility system comes near its reserve capacity level, the utility will notify its customers on interruptible service that their supply of electricity will be interrupted. Many heavy users of electricity accept this risk because they have compelling reasons to keep their electricity bills low, and can switch their load requirements to other times of the day. Other customers may have elements of one or both types of service.

Some residential customers who generally have a very low usage rate may ask for a type of partial requirements service that uses utility-operated cut-off switches on their water heaters or other appliances in order to lower their bills. When many residential users have cut-off switches, the utility has greater flexibility in meeting its service obligation during critical highusage periods.

These classes of service also provide utilities with the means to adjust customers' bills. For example, utilities may pass along certain varying costs, such as fuel costs, that make up the total price of electricity. These adjustments allow utilities (1) to recover approved costs until new rate schedules are authorized, (2) to reduce demand, or (3) to shift the demand to another time period to reduce peak load.

\section{Generation and Dispatch of Electricity}

\section{Generation}

A utility's generating plants vary by size of the unit, fuel use, age, and intended usage. Major fuel sources for these power plants include coal, uranium, water, natural gas, and oil. Electric utilities are actively developing biomass and geothermal sources where available. Solar, wind, tidal, and other technologies are currently minor sources of power for generation.

Some plants, called baseload plants, handle a large constant portion of the customer load (Figure 6). These plants are generally larger, newer, and highly efficient. Another set of plants, referred to as intermediate plants, serves a more variable customer load not covered by the baseload plants. They are usually older and 
more expensive to run, and are used after all the available baseload units are dispatched. Other plants, called peaking plants, handle only the highest peak loads. These plants are usually equipped with turbine units or combined cycle units; they are quick-starting but very expensive to run. Other types of peaking plants include hydroelectric pumped storage plants and some conventional hydroelectric units. Appendix A describes the various kinds of plants that a utility may have available to meet customer load.

Utilities also have reserve or stand-by plants. These plants are usually older, less efficient, and more expen- sive to run; they operate if there is an unexpected increase in customer load or to support the electrical system during a plant or transmission line outage.

\section{The Electric Utility System}

An electric utility must balance its customers' demands for electricity continuously with the most economical operation of its system. The utility must try to use the lowest cost generating capacity available to meet the

Figure 6. Typical Generation Dispatch, Summer Peak Day

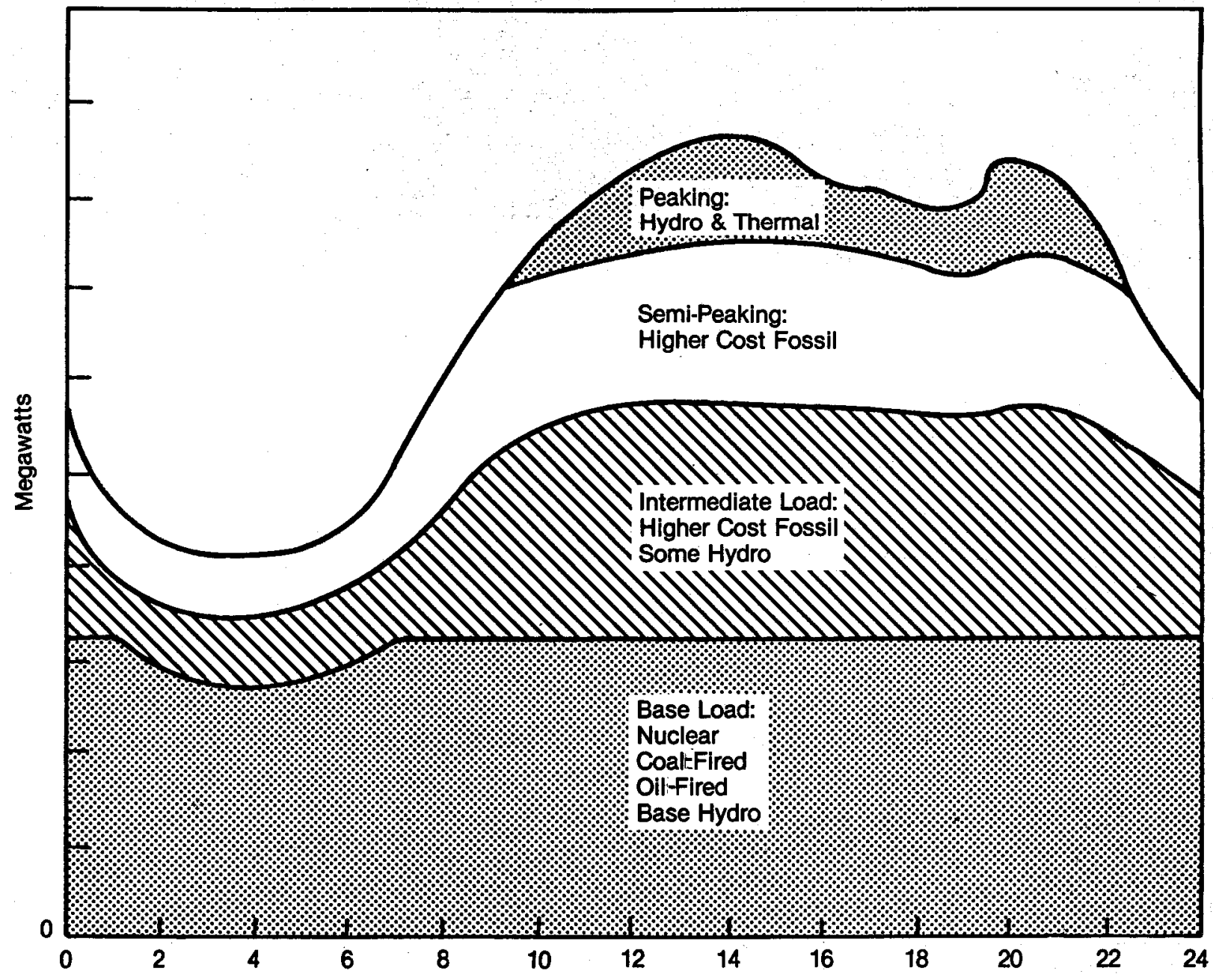

Hours

Source: Task Force No. 4 of the Electric Power Research Institute, Edison Electric Institute, American Public Power Association, and the National Rural Electric Cooperative Association for the National Association of Regulatory Utility Commissioners, "Comments on Two Costing Approaches for Time-Differentiated Rates," Electric Utility Rate Design Study, (March 8, 1977), p. 83. 
changing load by adjusting the mix of generating units in use or by purchasing energy from outside its system.

Economical system generation is highly dependent on the type and size of the actual customer load. A large load affects the thermal efficiency of a plant by allowing the plant to run at its optimal production level. This affects the economical operations of the whole electrical system, because it is far more efficient to have power plants running at favorable cost levels than to have underutilized available capacity. In an efficient system, the most economical plants are kept operating at their best efficiency for the longest duration of time.

The unit cost of producing power is cheapest for the whole electrical system when the large generation plants are meeting the load and are operating at close to their designed capability. But the operating cost of producing power is only part of the total economics of power production. Fixed charges (interest on the plant investment, depreciation, taxes, and insurance) must be paid whether the plant runs or not. These fixed costs are recovered by the electric utility from each individual plant's output, or from sharing the cost to the system for nonoperating plants.

However, many of the highly efficient plants are not located close to the system load centers or the plants may be unavailable because of plant maintenance or other problems. The use of these plants may also be constrained by transmission capacity limitations and higher costs associated with long-distance transmission, so the utility must use less efficient plants that raise the overall cost of producing power.

\section{Control and Dispatching}

The utility control center, whether operated independently or used to control a power pool, unifies the separate utility functions into a coordinated and efficient power supply system. In its daily operations of dispatching power, the control center: (1) records the flow of electricity at the customer load centers and the entering and exiting amounts on its transmission lines, (2) watches the transmission connecting points for each interconnected electrical system, and (3) monitors the power flow from each generation plant. It determines the power available from its system; balances the unitgeneration costs with buy-or-sell opportunities with other utilities; coordinates the interutility transactions; examines what plants must be dispatched to avoid technical system problems or undue economic costs; and accounts for system power losses. It also projects demand requirements in order to determine how much capacity will be needed and when. These projections may be done hourly, daily, weekly, or at longer intervals.

The operations control center is designed to load automatically the generating facilities as needed, and to maintain the electrical system at the correct operating frequency. Deviations in the scheduled power flows or from the standard system frequency automatically cause compensating changes in the output at the generating plants. ${ }^{31}$ These deviations can mean there has been a loss or gain of a customer load, a plant or line has suffered a forced outage, or some plant or line has been returned to the system. Any of these changes can require some review or action by the control center.

As part of a group of interconnected electrical systems, an electric utility is responsible for keeping the interconnected network efficient. It must maintain the system frequency for its service territory by watching its own customer load and taking responsibility for that load when changes occur. Stabilizing the system frequency is made easier by coordination with other electric utilities and by drawing from a larger base of online capability. Load changes are absorbed by all the electrical systems, and many of the increasing and decreasing load changes cancel out or offset each other, so that the effect on the entire system is less than it would be on an individual utility. Also, each generating unit in the system is freed from the necessity to make continual large changes in production levels.

The power flow, in alternating current electrical systems, is over the existing lines, so the transfer of energy from the generating facility to a final end-user takes any/all electrical paths available. ${ }^{52}$ Controlling and monitoring electric utility interconnections is a major function of the control center and requires a strong communication and telemetering system. Power transfers must be continuously recorded at all major points in order to account for the scheduled and unscheduled power flows, and to allow for accurate payment or compensation.

\footnotetext{
${ }^{51}$ On an interconnected electrical system, when customer load increases from a steady state condition, each generating unit on line in the entire interconnected system automatically picks up its share of the new load. Then the electrical system where the load originates takes over and increases its generation to meet the load increase; the other electrical systems then reduce their generation accordingly. The resulting inadvertent power flows, after scheduled interchanges are taken into account, are identified, and the monthly net balance of each utility is handled under its interconnection agreements. size.

${ }^{52}$ Electricity finds the path of least resistance over one or more lines in accordance with the design and length of the lines, and conductor
} 


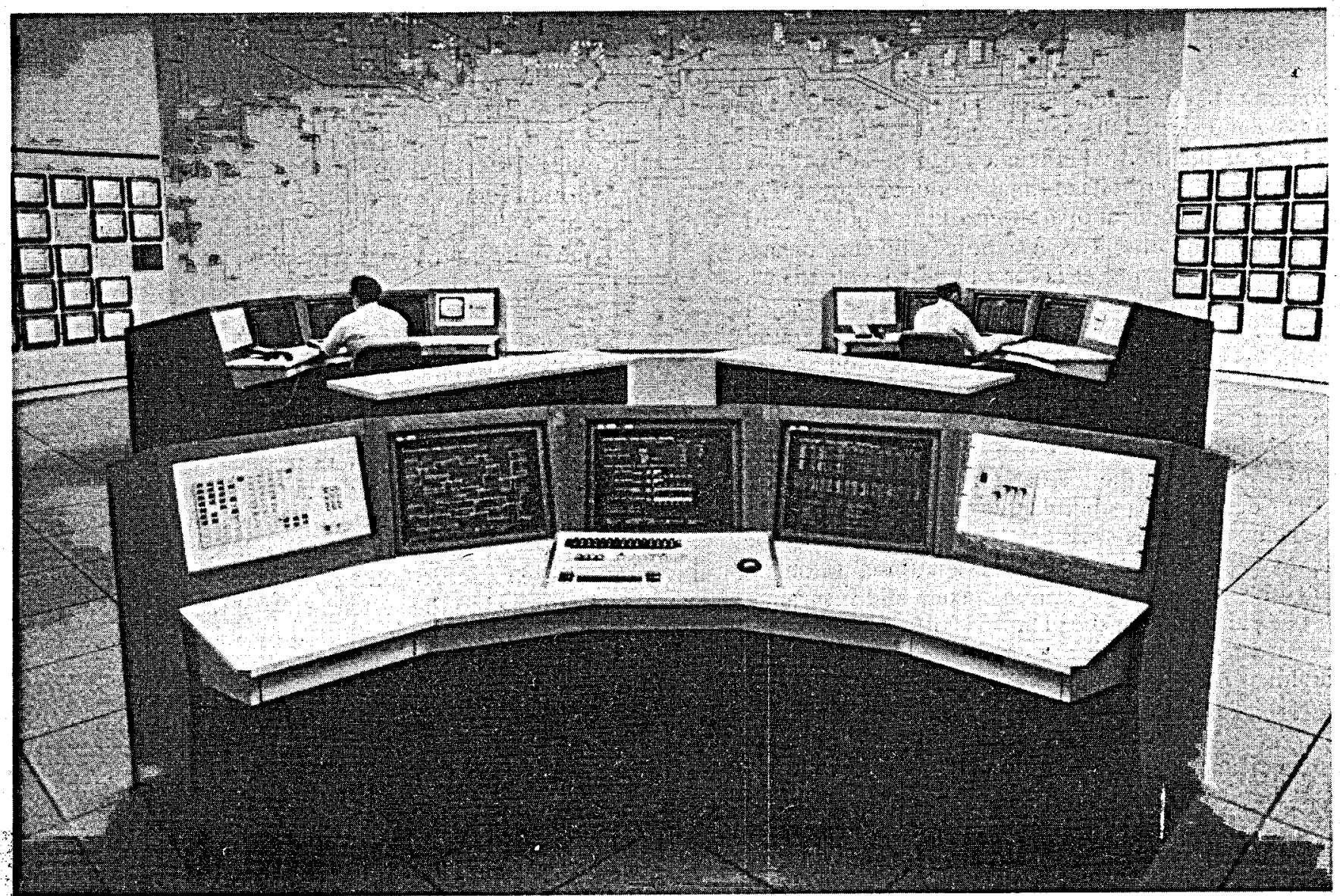

This system control center coordinates the electricity needs of the seven-State American Electric Power System.

\section{Transmission Systems}

\section{Transmission and Distribution}

The electric utility industry designed and built its large transmission system principally to provide an efficient and reliable electrical transfer system to its own customer base. The system was also designed to enhance system dispatching and stability, and to provide alternate connections to load centers.

The electrical transmission system is separated into two different segments. One segment is the bulk power system, sometimes called the transmission system; the other is called the distribution system. The transmission system handles major movements of energy from the points of generation and the interconnections with other utilities to the points where electricity is usually transformed to a lower voltage for delivery in a service territory. The distribution system is the portion of the system and facilities that has been separated from these higher voltage bulk power transfers and is dedicated to delivering electrical energy to the end users.
The types of transmission and distribution voltages used range from the extra-high alternating current and direct current lines to the service lines that connect to residential homes. Many types of voltage and lines are used by the electric power industry to handle different operating conditions and to minimize overall cost. Utilities try to keep the number of voltages to a minimum in both the transmission and distribution system in order to reduce the changes from 'one voltage level to another. The coordination and maintenance of these lines and equipment entails extensive planning for cost control and service to the customer. Transmission costs rise rapidly with distance, and transmission systems have a very high associated capital cost because of the expensive terminal and substation equipment.

In planning for the upkeep of current lines and for additional lines, utilities must balance cost, practicality, and system reliability. Utilities take into account the rural, suburban, and urban routes; the environmental and the aesthetic impacts of the lines and equipment; the expected power flows; and the concentration of lines in urban areas and transmission rights-of-way. They also must avoid cascading faulting (a multiple failure of system components). Finally, they must contend with climatological and geographical conditions that affect the lines and equipment, and the future magnitudes of power transmission needed to meet planned customer load. 


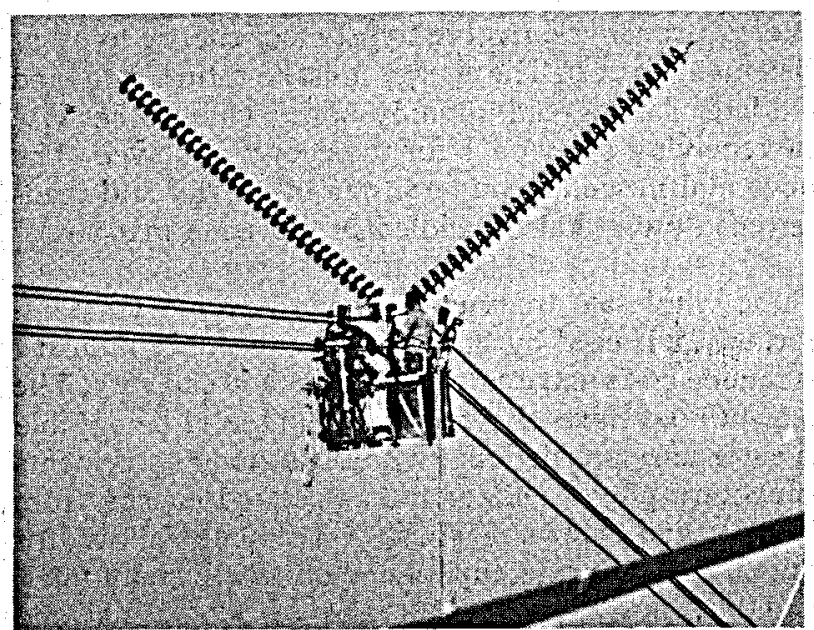

Electric utility linesmen install hardware on a 765-kilovolt transmission line.

\section{Integrated Transmission Systems}

An integrated transmission system allows a utility to use all the generating resources available more economically, to reduce its dependency on reserve capacity by the use of other external sources, and/or to manage its own load more efficiently. It also allows the combination of small customer loads into large ones. to

Because of the high social and commercial costs of an outage, the electric system must be able to operate in every normal condition and be able to recover rapidly from forced outages. The reliability and the stability of individual electrical systems are very critical to the interconnected electrical system.

Electric utilities try to reduce, isolate, or avoid outages by using (1) reliable high-speed connection and switch$\rightarrow$ ing elements that open and close the circuits safely; (2) reclosure equipment that will restore a faulted segment as rapidly as possible; and (3) relaying equipment that can identify and isolate the fault without bringing down the entire system. Other protection elements include equipment that regulates the voltage; equipment that handles the immediate short-term effects resulting from electrical impulses that are lightning- or system-induced; and general insulation control standards for all lines and equipment.

Electric utilities continually review the status of the entire system. These studies enable utilities to provide for adequate flexibility in controlling power flows and to identify restricted power flow problems; to establish better ways to handle emergency conditions; and to detect the possible use of inappropriate and costly line and terminal equipment, and obsolescence in lines and equipment.

\section{Interutility Transactions}

\section{Development of Interutllity Transactions}

\begin{abstract}
Interutility transactions or exchanges are used by electric utilities to share reserves and to provide mutual assistance in time of potential and actual needs. They allow the utility systems to take advantage of each utility's load diversity, whether it comes from time of day, from different seasonal usages, from the customer base composition, or from a more beneficial mix of generation capacity. They also allow each utility to conserve its own resources, to share the benefits of reduced operating costs with its customers, to receive emergency energy support from other utilities, and to reduce the cost of its own operating reserve requirements. $^{33}$
\end{abstract}

Originally, the savings from reduced or avoided production costs helped to interest the utilities in energy. transactions. The amount of energy involved is often far less valuable to a utility than the benefits achieved from not producing the energy within its own system. It is very advantageous to avoid building expensive additional capacity solely in order to handle occasional peak loads. Similarly, a utility benefits from being able to delay or stagger construction of additional baseload plants.

The use of the transmission system as a marketing vehicle for electricity transactions came about secondarily, generally after the interconnection system was designed and built. As a result, most transmission lines were not set up to handle daily wholesale transactions that utilize a high percentage of the line capacity. These transactions then must be balanced by the control center against better electrical system reliability and maintenance of frequency control. Often these wholesale transactions compete for line capacity with the best mix of available economic capacity.

\section{Wholesale Transactions}

\begin{abstract}
The Federal Energy Regulatory Commission (FERC) is responsible for regulating interstate wholesale transactions. Utilities file proposed rate schedules for transmission services and charges, and for the wholesale transactions. FERC must approve the filings before it allows the utilities to engage in these interutility sales, purchases, exchanges, or provide support to other utili-
\end{abstract}

\footnotetext{
${ }^{33}$ The price of the interutility transaction must be high enough to overcome the cost for transmission losses incurred over long distances. During emergency conditions, the cost of transmitted energy is less important than avoiding a forced outage and even less critical when the stability of the whole electrical system is involved.
} 
ties upon request. Other special transactions are sometimes negotiated for very large energy sales and exchanges that are to happen over a longer time. These special contracts are usually reviewed by FERC and other regulatory agencies that oversee the service territories affected by the agreement.

The transmission filings can be divided into firm carrying capacity, interruptible carrying capacity, thirdparty transfer capacity, and an "other" category. Wholesale transaction filings can be grouped into capacity sales, energy sales, energy exchanges, and an "other" category. ${ }^{54}$ Wholesale electric transactions are further divided by duration of the sale, and the type of capacity and energy sold. The length of the sale can be for one hour, one day, one week, a month or several months, a season, several years, or some combination of these time periods. The "other" categories usually cover the utilities' responsibilities to one another during normal and emergency conditions, operating reserves support, diversity exchanges, and unscheduled or inadvertent energy flows.

Capacity sales are usually considered firm sales in which the associated energy must be taken, or paid for if not taken; and the delivery is scheduled during normal system operating conditions. This capacity may be made available from the entire system or from an identified generating unit. The capacity offered in these transactions may be available only during a set period of seasonal diversity, an off-peak time of the day, or from a particular fuel-fired generation capacity that is currently not fully utilized. The energy associated with this capacity sale, if acquired, has a separate cost schedule from the capacity charge attached to each kilowatt of power.

The energy, economy, or interruptible sales are often based on splitting the benefits gained by the parties involved. They are used to gain operational savings, such as avoiding the use of expensive fuels, and selling electricity generated by the spillage of excess reservoir water.
Energy exchanges involve transfers of energy to other systems at no cost. The energy must be returned in kind at a later date agreed upon by both parties, otherwise the receiving party pays for the energy received. The incidental miscellaneous transfer of energy and inadvertent flow are also handled in the same manner.

These wholesale transactions have become very important tools used by the U.S. electric utility industry to reduce costs and avoid expensive new capacity. The U.S. utilities have also taken advantage of being able to enter into international wholesale trade agreements to acquire power and/or the associated energy from Canada and Mexico. These agreements allow for mutual system protection. They cover diversity sales, economy power sales, and sales of geothermal and inexpensive hydroelectric power. The benefits from these international transactions also include the ability to buy inexpensive energy, to delay expensive capital construction, and to acquire additional emergency protection.

\section{Summary}

The goal of the electric utility is to balance its entire system to achieve the lowest cost of service. This requires constant review and planning to bring together all the highly integrated economics of production, control, transmission, and distribution of electric energy at a cost the customer accepts.

The transmission lines are used by the operations control center to tie each operating segment of an electric utility into an integrated electrical system. The utility's control and dispatching of this flow of electricity from the generation facilities and other utilities to the load centers is the key factor in matching customer demand with the least-cost electrical generation or with purchased power. The utility watches its transmission system in order to meet changes in operating conditions, to control its own customer loads better, and to prepare for the future needs of its customers.

\footnotetext{
54Further information on these filings is available from the Division of Public Information, the Federal Energy Regulatory Commission, Washington, DC.
} 


\section{OUTLOOK FOR ELECTRIC POWER, 1985-1995}

The outlook for the electric utility industry through 1995 depends on several factors, including the level of economic growth, the price and availability of fuels, the price of electricity relative to other competing energy sources, and the quantity and types of new plant construction. As with any attempt to predict future trends, these factors are surrounded by considerable uncertainty. This chapter presents a range of projections for electricity supply, demand, and prices from the Annual Energy Outlook 1984. Included are a basecase forecast and alternate projections under assumptions differing from the base case. These projections are intended to illustrate potential outcomes and trends.

Most of the projections are provided at the national level. Some results are described at the level of the Federal Regions, but these projections are inherently more uncertain than those at the national level because of a lower level of aggregation for each fuel and sector (Appendix C).

The base case, also known as the middle economic growth case, incorporates explicit assumptions about economic growth and world oil prices as well as implicit assumptions embodied in the representation of the electric utility industry and related energy markets. Strong economic growth is expected to continue through 1995 although the economic expansion is expected to occur at a slower rate than observed in 1983 and 1984, when the growth rates of real gross national product (GNP) were about 3.7 and 7.0 percent, respectively. ${ }^{55}$ Combined with expectations of a relatively low inflation rate and moderate world oil prices, the strong economic growth is projected to result in higher levels of energy demand. The base case also assumes no fuel supply disruptions and no cancellations of new generating plants currently planned or under construction.

Alternate cases examine the effects of lower (than the base case) economic growth, higher economic growth, reduced capacity additions, and reduced capacity additions under low, high, and base case economic growth assumptions. Although world oil prices are surrounded by considerable uncertainty, no alternative oil price scenarios are discussed in this report because the impact of lower and higher prices on utility oil and natural gas use is almost negligible, as utilities have shifted away from these fuels since the oil embargo in 1973.

The results of the projections can be particularly sensitive to the input assumptions, but several general trends emerge from the base case and sensitivity cases. The recent upturn in electricity demand growth is expected to continue during the forecast period. Although the projected growth rate does not approach the rates observed during the 1960's and early 1970's, electricity demand is expected to grow more rapidly than in the decade following the embargo. The electricity demand growth is expected to exceed the GNP growth during the forecast period because consumers prefer electricity over other energy sources. The projected relationship between electricity demand and GNP is similar to the pattern observed prior to 1980 , but it represents a reversal of the trend that has occurred in the 1980's.

Electricity has become an increasingly important energy source over time, and this trend is reinforced by real electricity prices that are expected to remain stable or even to decline slightly through 1995 . This projected price path for electricity is based on assumptions of stable or declining fuel costs in the early years and declining capacity expansion programs in the later years.

Supplies of electricity are projected to be adequate over the forecast period, although difficulties in meeting peak demands could occur if economic growth results in electricity demand growth that is higher than expected, or if unanticipated delays and cancellations of new generating capacity occur. The shift away from use of oil and natural gas is projected to continue as new nuclear and coal-fired capacity, which account for almost 90 percent of the scheduled capacity additions during the forecast period, become available. Investorowned utilities are expected to continue to dominate electric utility capacity, generation, sales, and revenue as they control more than 70 percent of the scheduled capacity increases during 1985-1995.

${ }^{55}$ Energy Information Administration, Annual Energy Outlook 1984, p. 7. 


\section{Base Case}

\section{Demand}

Although the GNP growth rate has exceeded the electricity demand growth rate in the early 1980's, this trend is expected to be reversed during the forecast period. Electricity demand is projected to increase by 3.4 percent per year between 1985 and 1990, compared to an assumed growth rate in GNP of 3.1 percent per year. For 1991 through 1995, electricity demand is expected to grow by 3.1 percent per year as the growth rate in GNP slows to 2.3 percent per year. Electricity, as a share of total end-use energy consumption, is projected to be 14 percent in 1985, 15 percent in 1990, and 17 percent in 1995 (Table 5).

Historically, the industrial sector has been the largest consumer of electricity. This trend is expected to continue as industrial demand for electricity is projected to increase from about 35 percent of total end-use electricity demand in 1985 to 39 percent in 1995. The distribution of electricity consumption among the enduse sectors is not expected to change significantly during the forecast period. Residential and commercial electricity demand is projected to increase absolutely during the forecast period, but the growth is expected to be less rapid than in the industrial sector, and the respective shares could decline slightly. The residential share is projected to account for about 34 percent of the total electricity demand in 1985 and to fall to about 32 percent in 1995, while the commercial share is expected to be about 31 percent in 1985 and 30 percent in 1995.
Despite the projected decline in the residential and commercial shares of total electricity demand, electricity is expected to be an increasingly important energy source in both sectors. Electricity is expected to account for nearly all the projected increase in residential energy consumption over the forecast period. Electricity, as a percentage of total commercial energy demand, is projected to increase to 39 percent in 1985 and 44 percent in 1995.

The electricity demand growth is expected to have considerable regional variation. The average annual growth rate between 1985 and 1995 is projected to range from 2.1 percent in the New York/New Jersey Region to 3.9 percent in the Northwest Region (Appendix C). The South Atlantic, Southwest, North Central and West Regions are also expected to have demand growth rates above the national average.

\section{Generating Capacity}

Completion dates for new generating capacity are based on data reported by utilities. All new nonnuclear units are assumed to begin operation as currently scheduled. Some projected nuclear units that have experienced construction stoppages or severe financial difficulties are assumed to be delayed beyond the utility estimates. It is assumed that all new units currently projected by utilities will be completed and will enter the ratebase.

It is assumed that licensing and construction take about 3 years for a turbine, 5 years for a hydroelectric unit, 8 years for a coal-fired steam plant, and 10 to 15 years

Table 5. Total End-Use Energy Consumption and Electricity Sales, Selected Years (Quadrilion Btu per Year)

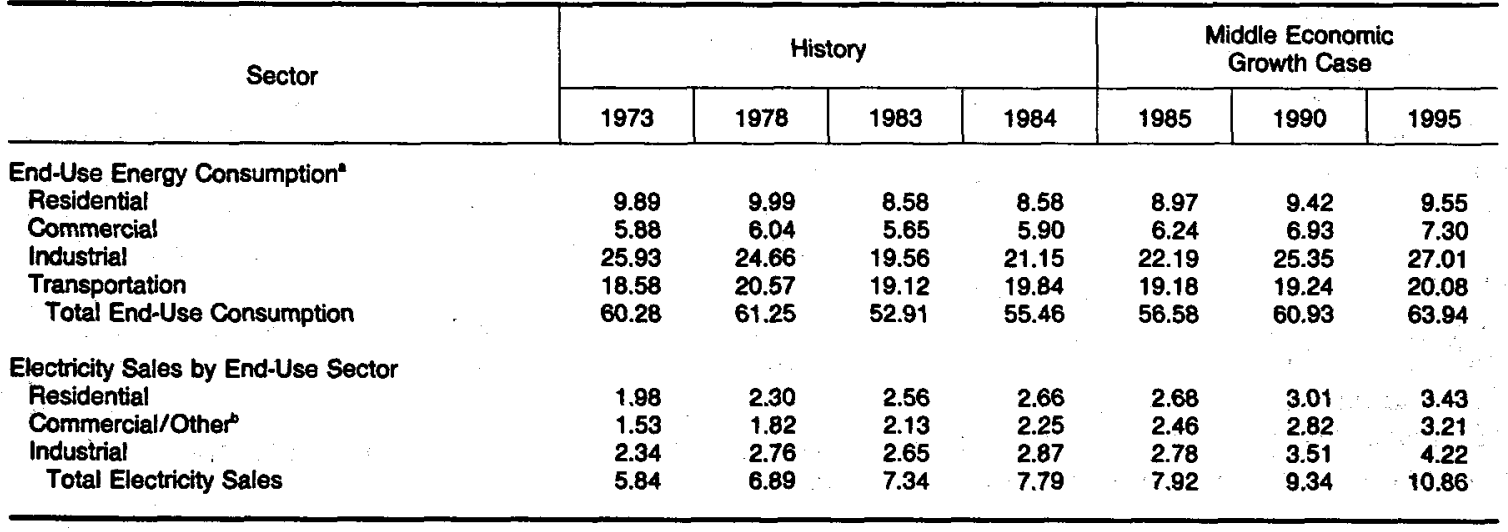

- Include electricity sales but not electrical energy losses.

Other includes street lighting and the transportation sector. Transportation electricity use accounts for about 0.01 quadrilion Btu per year.

Note: Totals may not equal sum of components because of independent rounding.

Sources: Historical consumption data are based on the Energy Information Administration, Monthly Energy Review, December 1984 (March 1985). AProjected consumption data are from the Energy Information Administration, Annual Energy Outlook 1984 (January 1985). 
for a nuclear unit. Because of long leadtimes, all of the nuclear units and most of the coal-fired plants expected to be completed during the forecast period are already under construction. Some coal-fired units beyond those currently planned could begin operation by 1995 if the orders are placed very early in the forecast period and no delays occur. Hydroelectric capacity additions are assumed to be limited to reported plans.

Capacity additions totaled 17 gigawatts in 1984. Projected capacity additions include 23 gigawatts in 1985, 60 gigawatts from 1986 through 1990, and 46 gigawatts from 1991 through 1995 (Table 6). Although some turbines and hydroelectric plants are expected to be added during the forecast period, projected coal-fired and nuclear units account for about 88 percent of these capacity additions. Significant nuclear capacity is projected to be added through 1988 , with additions tapering off thereafter.

Total generating capacity, excluding capacity currently out of service or in inactive reserve, is expected to increase from 664 gigawatts at the end of 1984 to 792 gigawatts at the end of 1995--an average increase of 1.6 percent per year. Capacity additions are projected to decline considerably during the latter half of this period. From 1985 through 1990, the projected average annual rate of capacity growth is 2.0 percent. From 1991 through 1995, the corresponding growth rate is projected to be 1.2 percent, the lowest sustained capacity growth since the early 1930 's. Projected capacity additions include 10 gigawatts not currently planned or under construction that are expected to be required by 1995 to meet the projected level of electricity demand. This capacity could include some coal-fired steam capacity but is expected to consist primarily of gas turbines, which have relatively short construction periods and require much less capital than other types of generating capacity.

Reliability problems could occur in the 1990's in light of the continued absence of new construction announcements and the projections that electricity demand will grow faster than the additions of new generating equipment. Consequently, utilities are projected to have less unused capacity relative to demand, thereby reducing their ability to respond to unexpected demands or equipment downtime.

The timing and severity of the reliability problems depend on actual electricity demand growth and the capacity additions actually brought into service, and are expected to vary considerably by region (Appendix C). The reliability of electricity supply is projected to decline through the forecast period in all regions because the projected growth in demand is expected to exceed the corresponding growth in generating capacity. Particular areas of concern are the West and Northwest Regions, which are expected to require additional generating capacity by 1995 beyond that currently planned by utilities. In both regions, the projected growth rate for electricity demand is considerably higher than the expected growth rate for generating capacity. Because of its reliance on hydroelectric power, the Northwest could also experience reliability difficulties if adverse water conditions occur, such as drought. However, capacity shortages could also be mitigated by conservation, load management, electricity imports, or contributions to electricity supply from noncentral-station sources. Noncentral-station sources

Table 6. Electric Utility Capacity and Generation

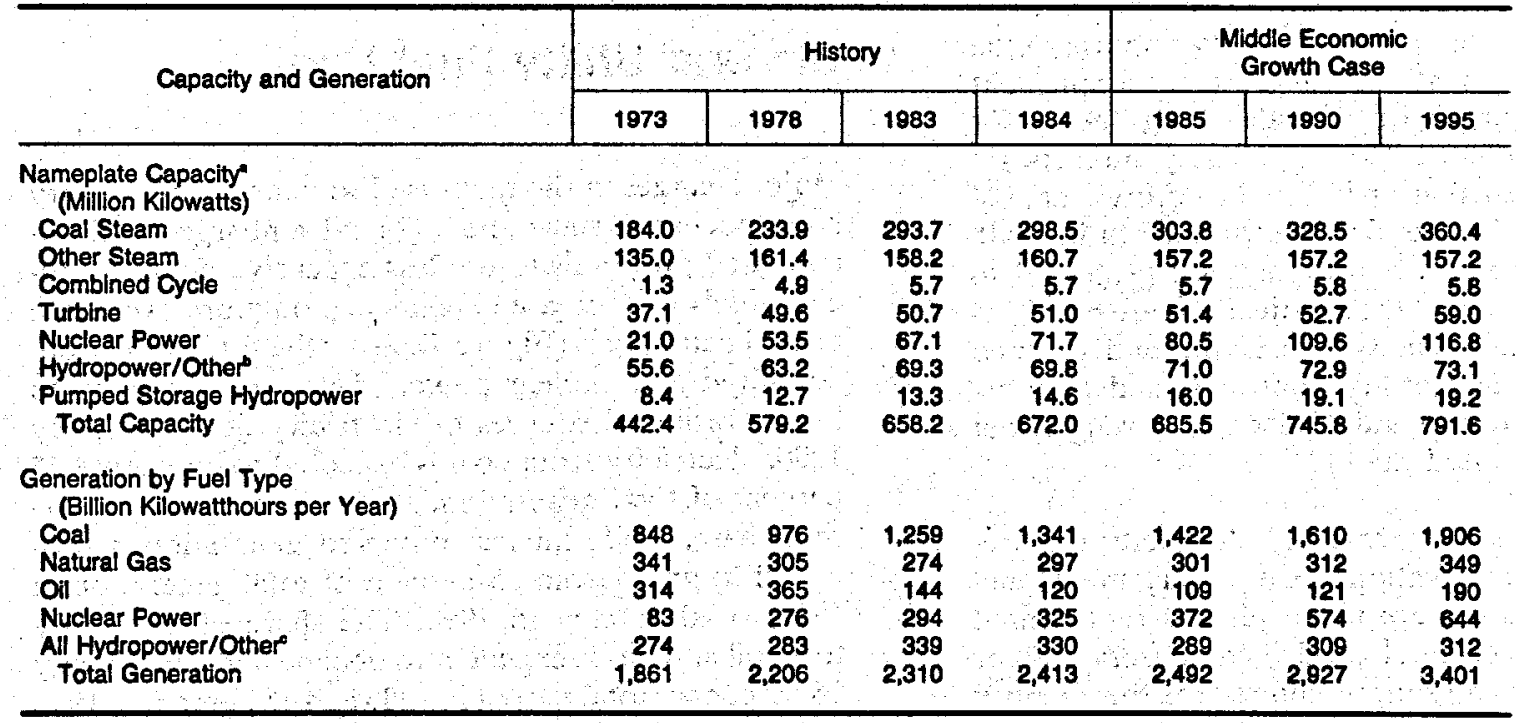

- Historical data for nameplate capacity include capacity out of service or in inactive reserve; projected capacity data exclude capacity out of service or in inactive reserve, which totals about 9 gigawatts.

- This category includes other renewable sources such as geothermal power, wood, waste, solar energy, and wind.

- This category includes conventional and pumped storage hydropower and other renewable sources such as geothermal power, wood, waste, solar energy, and wind.

Note: Totals may not equal sum of components because of independent rounding.

Sources: Historical data are based on the Energy Information Administration, Annual Energy Review 1984 (April 1985). Projected data áre from the Energy Information Administration, Annual Energy Outlook 1984 (January 1985). 


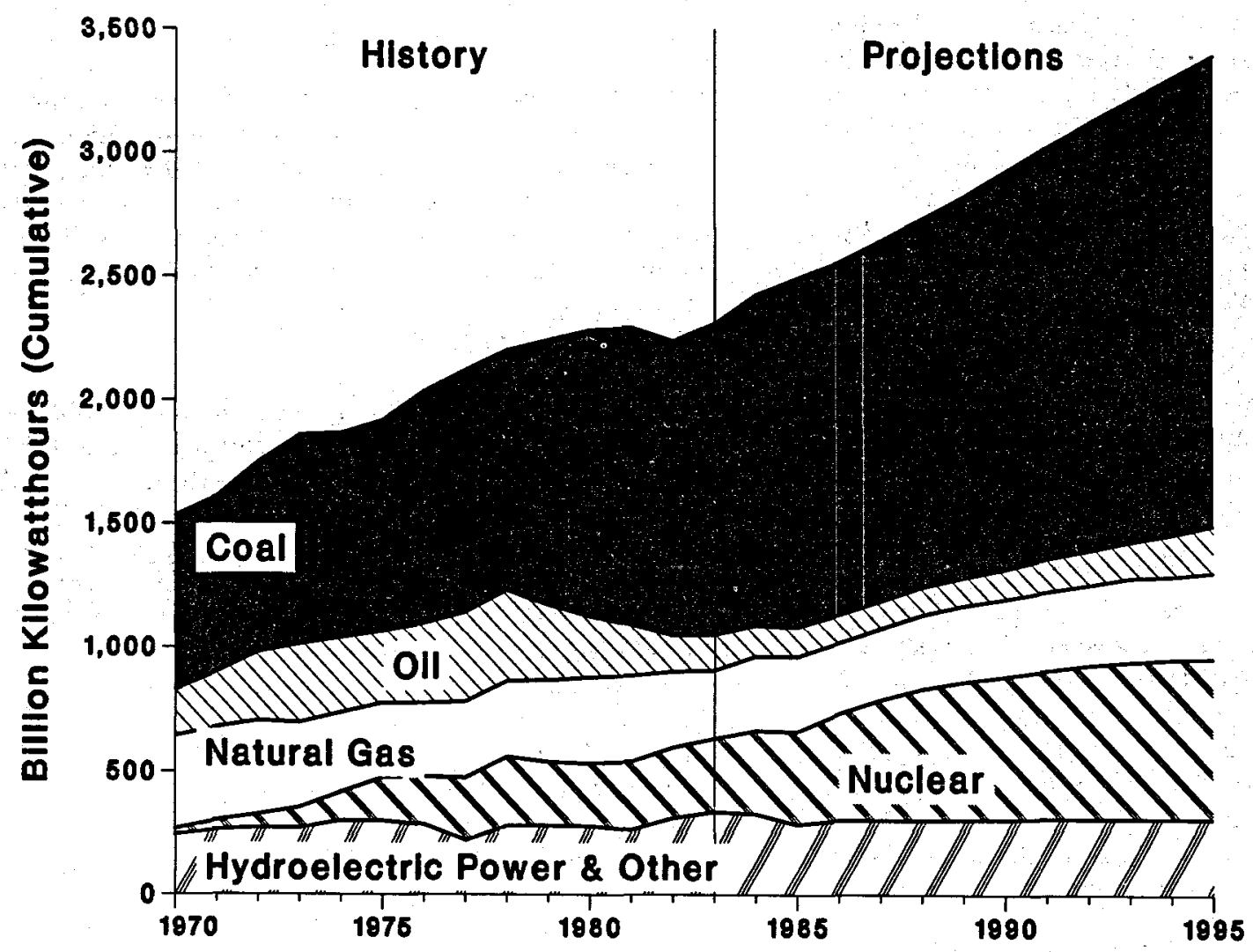

Note: "Other" includes renewable resources such as geothermal, wood, waste, solar, and wind. Source: Energy Information Administration, Annual Energy Outlook 1984 (January 1985), p. 40.

are considered to be plants not owned or operated by electric utilities.

Net imports of electric power to the United States from Canada and Mexico are assumed to rise from 1.6 percent of U.S. generation in 1985 to 2.3 percent by 1990 . This projection assumes that electricity imports to the United States will continue to grow to supplement domestic production, with Canada being the major source of these imports. Net electricity imports (in fossil-fuel equivalents) are projected to grow from 0.4 quadrillion Btu in 1985 to 0.7 quadrillion Btu in 1990 . In the post-1990 period, net imports are projected to remain nearly constant. These projections are predicated on the carrying capacity of existing and planned transmission lines and utility contracts, and they assume that both Mexico and Canada will remain net exporters to the United States.

Other means of meeting projected electricity requirements, such as conservation, load management, and noncentral generation, are not explicitly represented in the projections. Technology-driven conservation or enhanced load management would reduce the quantity of electricity demand without diminishing energy services operated by regulated utilities. Such facilities, which include cogenerators and small power producers, are encouraged by the Public Utilities Regulatory Policies Act of 1978 (P.L. 95-617) to produce and sell electric power to improve overall energy production efficiency. Noncentral generating stations would increase the available supply of electric power.

\section{Electric Utility Fuel Use}

Major changes in the fuels used to generate electricity have occurred since the 1973 oil embargo. Utilities instituted programs to use less expensive coal and nuclear fuels to decrease dependence on more expensive oil and natural gas (Figure 7). Over the forecast period, coal-fired and nuclear power plants are projected to be the principal sources of electricity generation. By 1990, electricity from coal is expected to constitute 55 percent of total generation, about the same as its current share, while nuclear-powered generation is projected to grow from 15 percent of total generation in 1985 to 20 percent in 1990 . The share of electricity from oil and gas is expected to decline and supply only 16 percent of total output in 1985 and 15 percent in 1990 although total oil and gas consumption increase absolutely over this period. The shares of generation from hydroelectric power and other sources are projected to decline over the forecast period, given their much slower projected rates of capacity growth. 
In contrast, oil- and gas-fired generation is expected to increase in relative importance after 1990. Although the share of total electricity produced by coal-fired generation could increase slightly as more new plants begin operation, the proportion of electricity produced by nuclear plants is expected to decline by about 1 percentage point between 1990 and 1995 because of the tapering off of nuclear capacity additions. To compensate for this decline and the continued decrease in the share of generation from hydroelectric and other plants, oil- and gas-fired generation is expected to increase slightly to about 16 percent in 1995 .

Current regional fuel consumption patterns are not expected to change dramatically during the forecast period because the projected slowdown in capacity additions is expected to result in a greater reliance on existing capacity. Throughout the forecast period, oilfired generation is expected to account for the largest share of total generation in the New England and New York/New Jersey Regions (Appendix C). Gas-fired generation is expected to continue to be most prevalent in the Southwest and West Regions.

\section{Electricity Prices}

The real price of electricity is expected to decline slightly over the forecast period, at a rate of about $\mathbf{0 . 2}$ percent per year from 1985 to 1990 and 0.4 percent per year from 1990 to 1995 (Table 7).

The projected price patterns are primarily a result of the interaction between capital and fuel costs. The projected slowdown in new power plant construction is expected to result in a lower growth rate for generating capacity than for electricity demand, thereby reducing the capital cost per unit output, especially in the later years of the forecast period. Higher utility fuel costs resulting from moderately increasing fuel prices and increased consumption of oil and gas are not expected to offset the projected declines in capital costs.

The real price of electricity also declined in the 1960's, but this decrease resulted from declines in both the capital and fuel cost components. However, the historical decrease in capital costs was due to economies of scale in the design of power plants rather than a slowdown in new plant construction. The decline in utility fuel costs observed in the 1960 's resulted from falling fuel prices and improved plant efficiencies.

Although the real price of electricity, at the national level, is expected to decrease between 1985 and 1995, it is projected to increase slightly in the New England, Southwest, West, and Northwest Regions (Appendix C). In each of these regions, the projected decrease in the capital cost component is not expected to be sufficient to offset the increase in fuel costs. The real price of electricity is projected to vary widely among regions. Throughout the forecast period, the electricity price in the Northwest Region, which is dominated by publicly owned hydroelectric plants, is expected to be less than half the prices in the New England and New York/New Jersey Regions, which are projected to have the largest shares of oil-fired generation.

\section{Sensitivities}

Some of the factors likely to have the greatest impact on the outlook for electric power are also surrounded by the greatest uncertainty. Of particular importance are the effects of changes in economic growth and generating capacity growth rate assumptions on electricity supply, demand, and prices. Alternate outcomes based on low and high economic growth, reduced nuclear and coal-fired generating additions, and changes in the level of economic growth coupled with reduced capacity additions are examined and compared

\section{Table 7. Summary of Components of Electricity Price}

(1984 Dollars per Thousand Kilowatthours)

\begin{tabular}{|c|c|c|c|}
\hline \multirow{2}{*}{ Price Components } & \multicolumn{3}{|c|}{ Middle Economic Growth Case } \\
\hline & 1985 & 1990 & 1895 \\
\hline $\begin{array}{l}\text { Capital } \\
\text { Fuel }^{\circ} \\
\text { Operations and }^{\text {Maintenance }} \\
\text { Total Price }\end{array}$ & $\begin{array}{r}25.53 \\
23.18 \\
15.51 \\
64.22\end{array}$ & $\begin{array}{r}23.84 \\
24.38 \\
15.32 \\
63.55\end{array}$ & $\begin{array}{l}19.28 \\
28.51 \\
14.65 \\
62.44\end{array}$ \\
\hline
\end{tabular}

- The capital component represents the cost to the utility of capital assets needed to provide rellable ser-

vice. It includes plant depreciation, taxes, and sufficient return of invested capital to cover interest obligations on outstanding debt and to compensate stockholders.

- The fuel component includes only the direct costs of fuel inputs used to generate electricity required to meet demand.

- The operation and maintenance (O\&M) component includes all nonfuel costs necessary to operate and maintain generation, transmission, and distribution capacity used to deliver electricity to end-use sectors.

- All prices are from model simulations and represent average revenue per kilowatthour of demand for the total electric utility industry.

Revenue requirements are projected from the financial information contained on the Federal Energy Regulatory Commission FERC Form 1 ,

"Annual Report of Major Electric Utilities, Licensees, and Others" and on the Energy Information Administration Form ElA-412,"Annual Report of

Public Electric Utilities,". and predecessor forms.

Note: Totals may not equal sum of components because of independent rounding.

Source: Energy Information Administration, Annual Energy Outlook 1984 (January 1985). 
to the base case. In each alternate case, individual assumptions pertaining to the sensitivity are varied while all others remain unchanged from the base case.

\section{Economic Uncertainty}

Economic growth is one of the most important factors determining energy consumption. The net effect of higher economic growth is to increase energy consumption. In periods of high economic growth, consumers purchase more goods and services, including energy for use in equipment such as highway vehicles and consumer appliances. The overall increase in energy demand resulting from higher economic growth is dampened, however, as energy prices are bid up in response to the higher levels of energy consumption. At higher energy prices, the cost of the higher energyusing services increase, and consumers reduce energy consumption. In addition, higher economic growth tends to accelerate improvements in the average efficiency of energy-using equipment, because the average age of such equipment declines as more new equipment is purchased.

Although electricity demand growth tends to be higher in periods of strong economic growth, the relationship between the two has varied widely. Historically, the electricity demand growth rate has generally exceeded the GNP growth rate, but the ratio has been declining in recent years. In the 1950's, electricity demand grew at a rate of 9.8 percent per year, ${ }^{36}$ while real GNP grew at a rate of 3.9 percent per year. ${ }^{37}$ From 1960 until the Arab oil embargo at the end of 1973, the electricity demand growth rates averaged 7.2 percent per year, but the GNP growth rate rose slightly to 4.0 percent per year.

Since the oil embargo, the average annual growth rates for both electricity demand and real GNP have declined considerably. Between 1973 and 1980, the average annual growth rates for electricity demand and GNP were 2.9 percent and 2.3 percent, respectively. For 1981-1984, the historical trend was reversed, as the GNP growth rate of 2.7 percent per year exceeded the electricity demand growth rate of 2.2 percent per year.

The decline in demand growth over the past decade, coupled with escalating construction costs, interest rates, and fuel prices, has contributed to many of the trends and difficulties currently confronting the electric utility industry. The low demand growth has exerted upward pressure on electricity prices, because the rising fixed costs resulting from the completion of new plants with higher per-unit costs had to be distributed among smaller electricity sales. The low demand growth and completion of new plants also led to an excess of generating capacity, which resulted in postponements and cancellations of other new plants in various stages of construction and licensing. However, a benefit of lower demand growth has been lower utility consumption of expensive oil and natural gas, the marginal fuels for electricity generation.

The rate of growth of electricity demand, a major source of uncertainty confronting the electric utility industry, has a significant role in utility decisionmaking, as it influences electricity production, the type and quantity of fuel consumed, capacity expansion, reliability, financing, and end-use electricity prices. The effects of various levels of economic activity on electricity demand are examined in the low, middle (base case), and high economic growth cases. Between 1985 and 1995, real GNP is assumed to grow by an average of 2.0 percent per year in the low case, 2.7 percent per year in the middle case, and 3.4 percent per year in the high case. The average annual rates of électricity growth during the forecast period in these cases are 2.7 percent, 3.2 percent, and 3.8 percent, respectively. The end-use consumption of electricity for each of these cases is dominated by growth in the industrial sector (Figure 8).

Higher growth rates of electricity demand increase the total available capacity required to ensure reliable electricity supplies. Across all economic growth scenarios, capacity additions above those currently planned are required to meet demand levels ranging from 3 gigawatts in the low economic growth case to 24 gigawatts in the high economic growth case.

In all three economic growth scenarios, coal-fired and nuclear plants are projected to supply most of the electricity (Figure 9). Because of low operating costs, nuclear plants are expected to operate at their assumed maximum rates, and total nuclear production is projected to remain constant across the economic scenarios. The share of total generation provided by nuclear power is projected to grow substantially in the base case, increasing from 13 percent of total generation in 1983 to over 19 percent in 1995 as new nuclear power facilities are completed. The nuclear share of total generation in 1995 ranges from 20 percent in the low economic growth case to 18 percent in the high economic growth case. Total coal-fired generation in 1995 is projected to increase by about 9 percent between the low and high economic growth cases. However, the corresponding increase in total generation is projected to be about 12 percent, so that the share of total generation in 1995 supplied by coal-fired plants is projected to fall from 56 to 55 percent between the low and high economic growth cases.

Because existing oil- and gas-fired plants have the highest operating costs, they are used to meet the electricity demand that cannot be satisfied by nuclear, coal-fired,

\footnotetext{
${ }^{36}$ Energy Information Administration, Annual Energy Review 1983, DOE/EIA-0384(83) (Washington, DC, April 1984 ), p. 197.

${ }^{57}$ Council of Economic Advisors, Economic Report of the President (Washington, DC, 1985).
} 
Figure 8. End-Use Electriclty Consumption: Comparison of Economic Growth

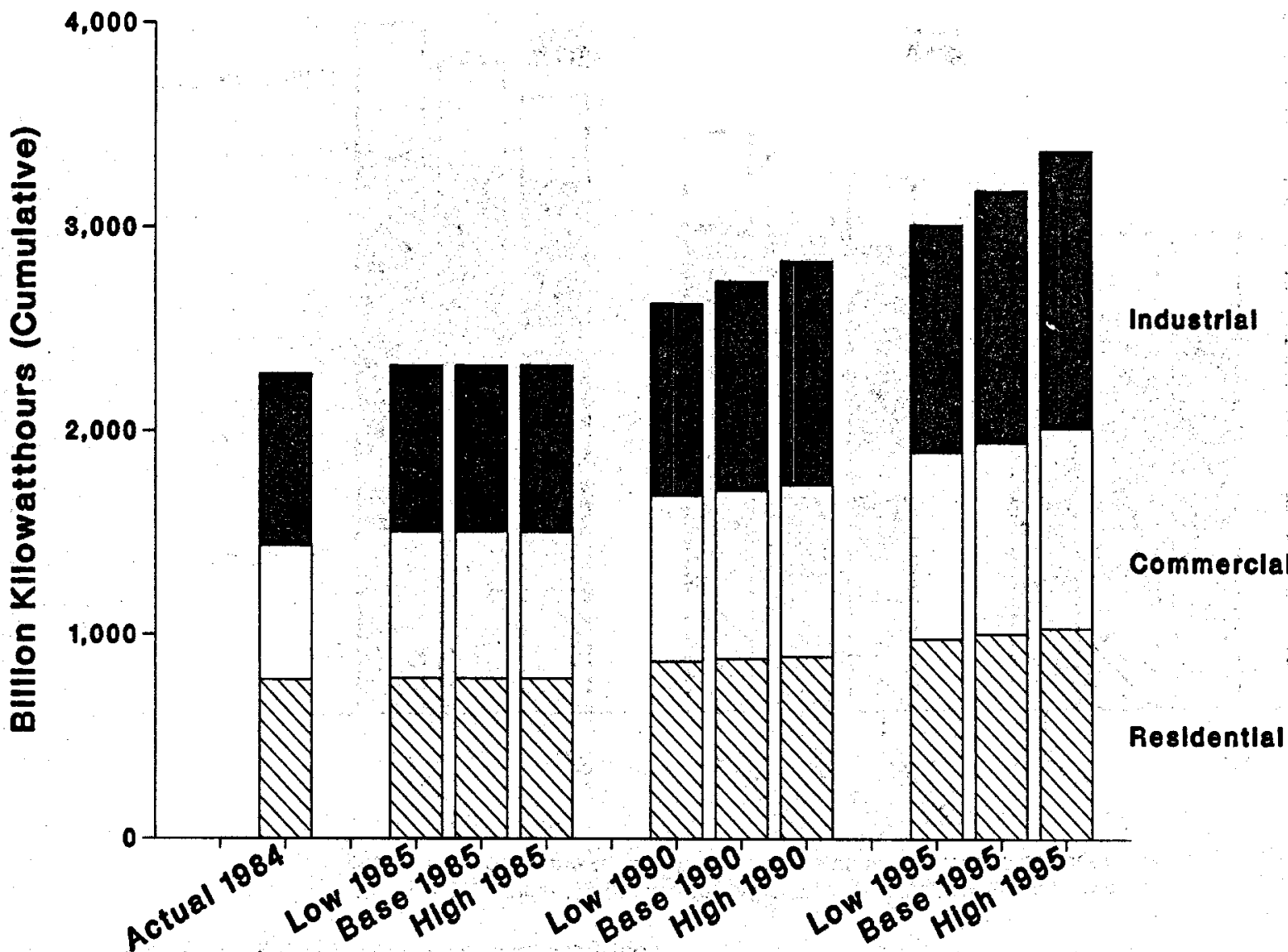

Sources: - 1984: Energy Information Administration, Electric Power Monthly (February 1985), p. 39; • Projections: Energy Information Administration, Annual Energy Outlook 1984 (January 1985), p. 149.

or hydroelectric plants. Since the demand growth over the forecast horizon is projected to exceed the planned capacity additions, even in the low economic growth case, utility consumption of oil and natural gas is pro. jected to increase absolutely across all economic growth cases compared to 1984 levels. In 1995, total oil- and gas-fired generation is projected to increase by about 50 percent between the low and high cases, and the oil and gas share of total generation is expected to range from 14 percent to 19 percent, respectively, compared to 17 percent in 1984.

The real price of electricity is projected to rise between the low and high economic growth cases because utility consumption of expensive oil increases as demand increases. In 1995, electricity prices could be about 7 percent higher in the high economic growth case than in the low economic growth case (Table 8). Although capital expenditures are expected to increase with demand, the capital cost per unit output could decline because the higher costs are spread over a larger base of sales. The per-unit operation and maintenance
(O\&M) cost could also decrease as demand increases because the share of electricity produced by oil- and gas-fired plants, which have relatively: low O\&M costs compared to coal-fired and nuclear plants, is expected to rise. However, the per-unit increase in fuel costs is expected to dominate the decline in per-unit capital and O\&M costs.

By 1995, the need for new generating capacity that is not already planned is projected to range from 3 gigawatts in the low economic growth case to 24 gigawatts in the high economic growth case. In the base case, currently planned capacity additions were expected to meet the demand growth during the entire forecast period except in the West and Northwest Regions. In the high economic growth case, the New England, Southwest, and Central Regions are also projected to face potential capacity shortages. The need for these unplanned capacity additions could be partially reduced by conservation, greater electricity imports, or production from sources other than the domestic supplies included in these projections. 
Figure 9. Projected Sources of Electrical Supply: Comparison of Economic Growth

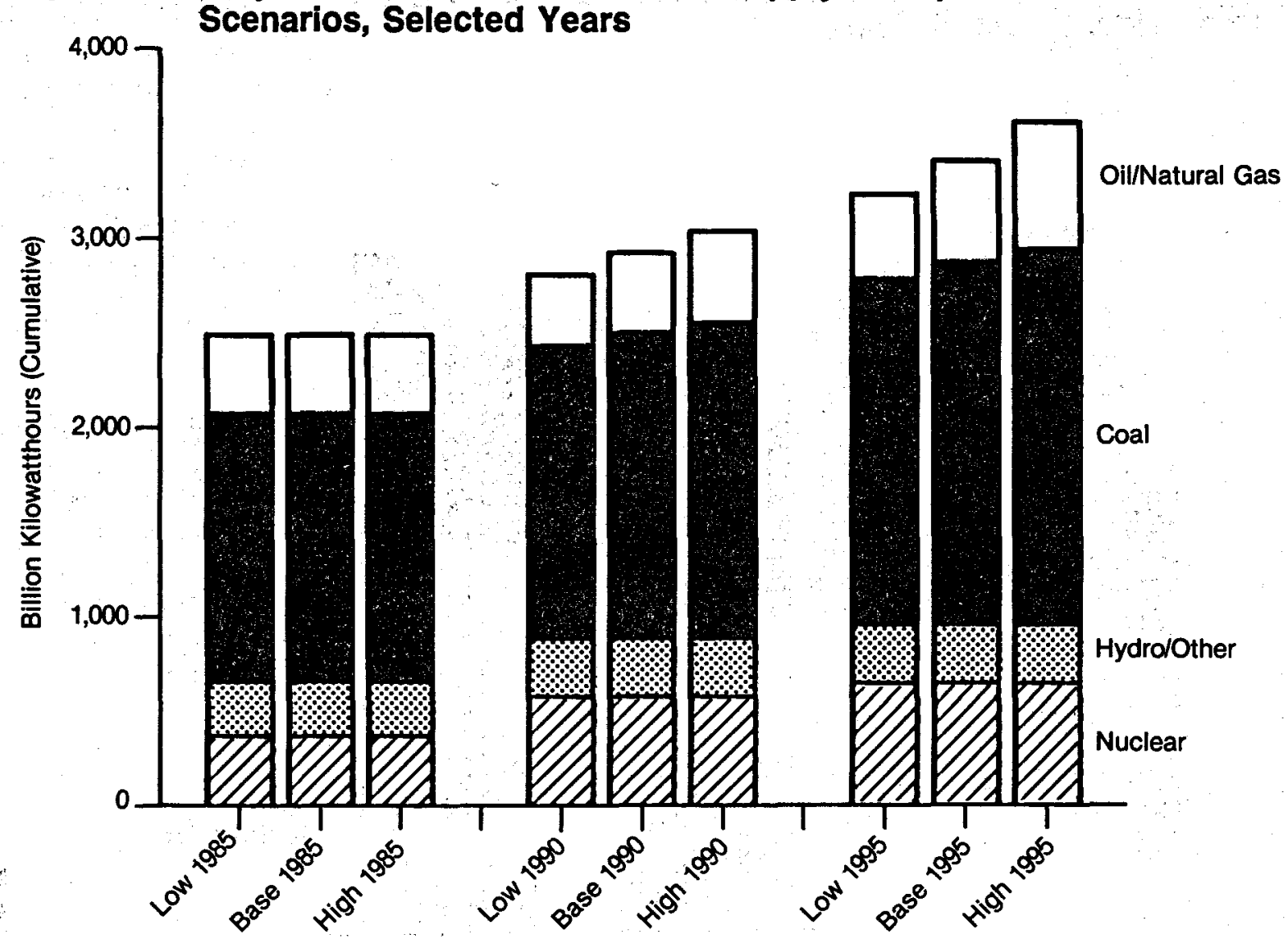

Note: "Other" includes renewable resources such as geothermal, wood, waste, solar, and wind.

Source: Energy Information Administration; Annual Energy Outlook 1984 (January 1985), p.150.

\section{Reduced Generating Capacity Additions}

Unanticipated reductions in electricity demand growth or unexpected financial difficulties could result in the cancellation of some of the projected capacity additions included in the base case. The "reduced capacity additions" case examines the impact on electricity supply, assuming that some of the projected capacity additions will be canceled. In the base case, 106 gigawatts of net capacity are projected to be added between the end of 1985 and the end of 1995 . These plants include 36 gigawatts of nuclear capacity and 57 gigawatts of coal-fired capacity, representing about 88 percent of the projected capacity additions during this period. The remaining capacity additions are gas- and oil-fired turbines, pumped storage, conventional hydroelectric, and other capacity.

In the reduced capacity additions case, assumed nuclear plant cancellations include those units that are currently less than 40 percent complete, or are experiencing severe financial difficulties, or where construction work at the site has stopped. Under these assumptions, nuclear capacity would be 77 gigawatts in 1985, compared to 80 gigawatts in the base case; in 1990, capacity would be 104 gigawatts, compared to 110 gigawatts in the base case; and by 1995, 105 gigawatts rather than

Table 8. Projected Electricity Price and Cost Components, Low, Base, and High Economic Growth Cases, 1995 (1984 Dollars per Thousand Kilowatthours)

\begin{tabular}{l|c|c|c}
\hline \multicolumn{1}{c|}{$\begin{array}{c}\text { Cost } \\
\text { Component }\end{array}$} & Low & Base & High \\
\hline Capital & 19.6 & 19.3 & 19.1 \\
Fuel & 26.4 & 28.5 & 31.7 \\
Operation and Maintenance & 15.0 & 14.7 & 14.3 \\
& & & 62.4 \\
Total Electricity Price & 61.0 & 65.0 \\
\hline
\end{tabular}

Source: Energy Information Administration, Annual Energy Outlook 1984 (January 1985). 
117 gigawatts. Also, planned coal-fired units with boiler shipments that have been postponed indefinitely are assumed to be canceled. The assumed nuclear and coalfired cancellations through 1995 total 17 gigawatts and represent about 12 percent of the projected capacity additions in the base case.

The primary consequences of these capacity reductions are projected to be less reliable electricity supplies, higher utility oil and natural gas consumption, and higher electricity prices. The electricity that would have been produced by the canceled nuclear and coal-fired plants could be produced instead by other new plants that were not projected to be built in the base case, or by existing capacity that was projected to be unused in the base case. Oil- and gas-fired units are generally the marginal sources of electricity supply because they use the most expensive fuels. The incremental utility oil and natural gas demand is expected to be met by imports of those fuels.

If the electricity demand growth in the reduced capacity additions case is the same as in the base case, cancellation of 17 gigawatts of planned coal and nuclear capacity is expected to reduce considerably the utility industry's ability to compensate for unexpected demands and equipment problems. In the reduced capacity additions case, 14 gigawatts of capacity currently neither planned nor under construction by utilities will be needed by 1995 to ensure adequate electricity supplies in all regions in the base case.

Coal and nuclear generation projections are strongly influenced by maximum capacity utilization assumptions, which determine the percentage of time power plants are allowed to generate electricity. Capacity utilization for both coal-fired and nuclear plants is projected to increase significantly between 1983 and 1995 despite the aging of the capital stock. The total system utilization rate is projected to grow from 41 percent in 1983 to 49 percent in 1995 in the base case. Many individual coal-fired and nuclear plants are currently operated at or above the level projected for 1995. High utilization rates are evident today in regions dependent on other more expensive fuels for electricity generation. For example, in New England the average utilization rate for coal-fired plants was 84 percent in 1983 while the average utilization rate for nuclear plants was 67 percent..$^{58}$ Nuclear and coal-fired plants are projected to continue to produce most of the electricity in the United States. In the base case, nuclear and coal-fired generation is expected to supply about 75 percent of the total electricity in 1995 , compared to 67 percent in 1983. By 1995, nuclear plants are projected to operate at their maximum utilization rates, but some regions could have coal plants that do not operate continuously because the demand is not expected to require full utilization of all coal capacity. In the reduced capacity additions case, cancellations could decrease the available coal and nuclear capacity by about 3 percent in 1995. However, the accompanying decline in nuclear and coal-fired generation is projected to be only about 2 percent; the loss of this generating capability could be partially offset by increases in the utilization of the remaining coal-fired plants, and by other new coalfired plants projected to be built to replace some of the canceled nuclear and coal-fired plants.

In the reduced capacity additions case, the share of total generation in 1995 produced by oil- and gas-fired plants is expected to increase to replace generation not available from coal-fired and nuclear plants. Total oiland gas-fired generation could increase by about 10 percent in this case. The projected increased utilization of oil- and gas-fired plants could increase the real price of electricity in 1995 by about 0.7 percent from the base-case level. The relatively small increase in price is expected to occur because the capital and O\&M costs are projected to be lower than in the base case. The capital costs are expected to decline because of lower capital expenditures resulting from the scaled-back construction plans. The decrease in O\&M costs could occur because oil- and gas-fired plants have lower O\&M costs than coal-fired and nuclear units. The sum of these cost reductions would be more than offset by the increase in fuel costs.

On a national level, the aggregate projections of electricity generation for the reduced capacity additions case are similar to the base case. However, the projected impacts have wide regional variations. For instance the South Atlantic could actually experience a slight decrease in electricity prices, compared to the base case, because it is projected to have unused coal-fired capacity that could replace some or all of the canceled capacity. The resulting increase in fuel costs could be relatively small compared to the decrease in capital costs. Conversely, some areas, particularly the New England, New York/New Jersey, Southwest, West; and Northwest Regions are expected to have reliability problems or higher prices if some of the planned coalfired and nuclear capacity additions are canceled. These regions are projected to compensate for the cancellations by relying more on existing oil- and gasfired plants, or by building additional capacity that is not yet currently planned.

\footnotetext{
${ }^{98}$ Regional capacity and generation data for 1984 are hot yet available. Coal-fired and nuclear plant generation data for 1983 are shown in Energy Information Administration, Electric Power Annual 1983, DOE/EIA-0348(83) (Washington, DC), p. 30 and p. 37, respectively. Coal-fired and nuclear plant capacity data are shown in Energy Information Administration, Inventory of Powerplants in the United States 1983, DÓE/EIA-0095(83) (Washington, DC), p. 14. Utilization rates are determined as follows:
}

$$
\text { Utilization Rate }=100 \times\left(\frac{\text { Annual Generation }}{\text { Capacity } \times \text { (Hours in the Year })}\right)
$$




\section{Reduced Capacity Additions Coupled With Low/High Demand}

Because of the uncertainty in the growth rate of electricity demand and the importance of demand in capacity expansion decisions, a range of implications of reduced capacity additions can be observed by combining the electricity demand growth rates for both the low and high economic growth cases with the cancellation of nuclear and coal-fired plant additions. At levels of higher demand, lower capacity could have a proportionately greater effect on electricity supply, prices, and reliability. The ability of the electric utility industry to compensate for capacity reductions could decrease as demand increases, because there would be less underutilized capacity available to produce additional electricity. Gas- and oil-fired plants would have to supply electricity at higher prices than those charged by utilities with new coal-fired and nuclear plants.

In the low economic growth case with reduced capacity additions, coal-fired generation could increase slightly by 1995 , as some regions have existing coalfired plants that are not projected to operate at their maximum levels and could more than offset the loss of the canceled coal-fired plants. In 1995, the rest of the electricity that would have been produced by the canceled plants is expected to be supplied by existing oil- and gas-fired plants, resulting in an 11-percent increase (about 50 billion kilowatthours) in utility oiland gas-fired generation compared to the low economic growth case without reduced capacity additions.

In the high economic growth case, the available coalfired units are already projected to be operating near their maximum rates, and the additional electricity that could be produced by these plants could only partially offset the electricity that could have been provided by the canceled coal-fired plants. The rest of the canceled coal-fired and nuclear plants could be replaced by existing oil- and gas-fired plants or new plants that are not currently scheduled to be built. If some new coalfired plants are built, total 1995 coal-fired generation could increase slightly, and the increase in oil- and gas-fired generation could be about the same as in the low economic growth case. Otherwise, the increase in oil and gas use by utilities could be substantially higher.

Because there is projected to be more unused capacity in the low economic growth case than in the high economic growth case, the impact of the cancellations on the ability of the industry to provide reliable electricity supplies would increase as the electricity demand increases. In the low economic growth case, about 2 gigawatts of the canceled capacity would have to be replaced, by either unplanned capacity additions, conservation, cogeneration, electricity imports, or efficiency improvements. In the high economic growth case, about 8 gigawatts of the canceled capacity would have to be replaced.
The increase in electricity prices between 1985 and 1995 caused by the reduced capacity additions is projected to range from 0.3 percent in the low economic growth case to 1.0 percent in the high economic growth case. In both cases, the capital and O\&M cost components are projected to decrease because of the canceled nuclear and coal-fired plants, which have relatively high capital and $O \& M$ costs. However, the increase in fuel costs, particularly in the high case, is projected to be large enough to outweigh the decline in capital and O\&M costs.

\section{Summary}

The projections described in this chapter are based on assumptions about whether past relationships can be expected to continue or change and are designed to illustrate possible future trends. They are not intended to represent a comprehensive set of outcomes; rather, they are designed to illustrate that there is uncertainty associated with some of the underlying factors such as economic growth and capacity additions and that other outcomes are likely if the underlying factors are changed.

The projected trends for electricity demand, prices, and supply indicate that the forecast period will be unlike any era in the history of the electric power industry. The growth rate of electricity demand is not expected to approach the robust levels observed prior to the Arab oil embargo; nor is it expected to decline rapidly as it did in the postembargo period. The real price of electricity is expected to be relatively stable, characterized by small increases and decreases instead of the steady decline that occurred before the embargo or the comparatively large increases that have occurred since the embargo. The projected economic conditions and electricity demand growth seem likely to result in fewer delays and cancellations than in the late 1970 's and early 1980 's, yet the expected capacity growth rate is much lower than in any historical period, including the postembargo era.

During the forecast period, the relationship between the expected growth rates for electricity demand and generating capacity is primarily responsible for many of the projected trends. Most regions are expected to have adequate supplies of electricity through 1995 because they have sufficient existing capacity to meet the incremental electricity that cannot be provided by new capacity. The increasing reliance on existing units is expected to result in higher consumption of oil and natural gas by utilities. However, there is some uncertainty whether aging existing units, which are generally characterized by lower operating efficiencies, higher O\&M costs, and higher outage rates, could provide an increasing share of the total electricity. If not, the need for capacity additions would be further increased. 
The impact of dwindling capacity expansion programs may not be fully realized until the post-1995 period. If the electricity demand growth continues to exceed the growth in generating capacity, a trend that is expected to intensify after 1990, all regions could experience considerable difficulty providing reliable and economical electricity supplies.

In addition to supply adequacy, the aging of existing capacity, and an increasing dependence on oil- and gas-fired plants, other areas of concern include: the financial condition of electric utilities, environmental and safety concerns, and the role of nuclear power. Each of these issues contributes to the uncertainty about the outlook for electric power and could be affected by factors that have not been discussed in this chapter. The next chapter addresses some of these factors and their potential impacts. 


\section{FACTORS AFFECTING THE OUTLOOK FOR ELECTRIC POWER}

Chapter 4 presents a range of EIA projections for electricity supply, demand, and prices from the Annual Energy Outlook 1984. This chapter identifies and briefly describes additional factors that may affect U.S. electricity markets over the forecast period.

\section{Bulk Power Transactions}

Increasing bulk power transactions may reduce some utilities' needs to build new generating capacity. Bulk power transactions are electricity exchanges among electric utilities. While some utilities have more baseload coal-fired or nuclear generating capacity than they currently need, other utilities must either rely on expensive oil- or gas-fired generation or build additional new baseload capacity. Increasing transactions between utilities could allow more efficient use of existing capacity. Increased transactions are appealing, given current high prices of oil and natural gas, escalating construction costs, high interest rates, concern over the environment, and safety issues.

There is disagreement over how to increase bulk power transfers. Utilities argue that the existing bulk power transmission system is already being used to maximum capacity in many cases, and that regulators block construction of new transmission capacity because of right-of-way, safety, and aesthetic issues. Utilities also fear that additional transactions with existing capacity will disrupt service. Regulators argue that utilities may fail to exploit existing transaction opportunities. They claim that utilities prefer to build new capacity rather than to buy power, partly because regulations allow a return on investment in new capacity, but not on investment in purchased power, and also because utilities traditionally prefer self-sufficiency. Further, utilities may view increased transfers as increased competition. Even more controversial have been proposals for increasing bulk power purchases from Canada and for requiring utilities to wheel (transmit) power from competitors to potential customers, particularly if the wheeling utility has already built capacity to serve those customers.

At present, the issue of expanding bulk power sales is being studied by utilities and regulators. Where transmission capacity is available, utilities are trying to increase these transactions. Increased bulk power transactions could reduce the consumption of oil and natural gas and may contribute to reduced demand for new generating capacity additions.

\section{Coal-Fired Power Plant Life Extension}

By 1995 more than 30 percent of the coal-fired steam generating capacity in operation in 1984 will be more than 30 years old; about one-third of this older capacity will be plants of greater than $200 \mathrm{MW}$ capacity. ${ }^{59}$ With the expected construction cost of new coal-fired capacity well over $\$ 1,200$ per kilowatt ${ }^{60}$ compared to anticipated renovation costs of less than one-half that amount, utilities are increasingly interested in extending the life of older units by another 20 to 30 years. Utilities are also investigating life extension programs for hydroelectric, oil-, and gas-fired and other power plants. Older plants can be refurbished in about 2 years, while 6 to 8 years are needed to license and construct a new plant. Life extension (refurbishment) of older power plants rather than new construction could be an attractive option to utilities.

Plant life extension efforts follow reexamination of overall utility system needs and involve a thorough review of plant design, equipment, performance, and operating and maintenance procedures, all subject to cost-benefit analysis. The resultant life extension program, if chosen, may involve changes in operations, changes in maintenance procedures, or selective replacement of plant components. Replacement may be

${ }^{59}$ Energy Information Administration, Generating Unit Reference File (GURF) (Washington, DC).

${ }^{60}$ Derived from Energy Information Administration, Projected Costs of Electricity from Nuclear and Coal-Fired Power. Plants, Vol. 1, DOE/EIA-0356/1 (Washington, DC, August 1982), p. xi. 


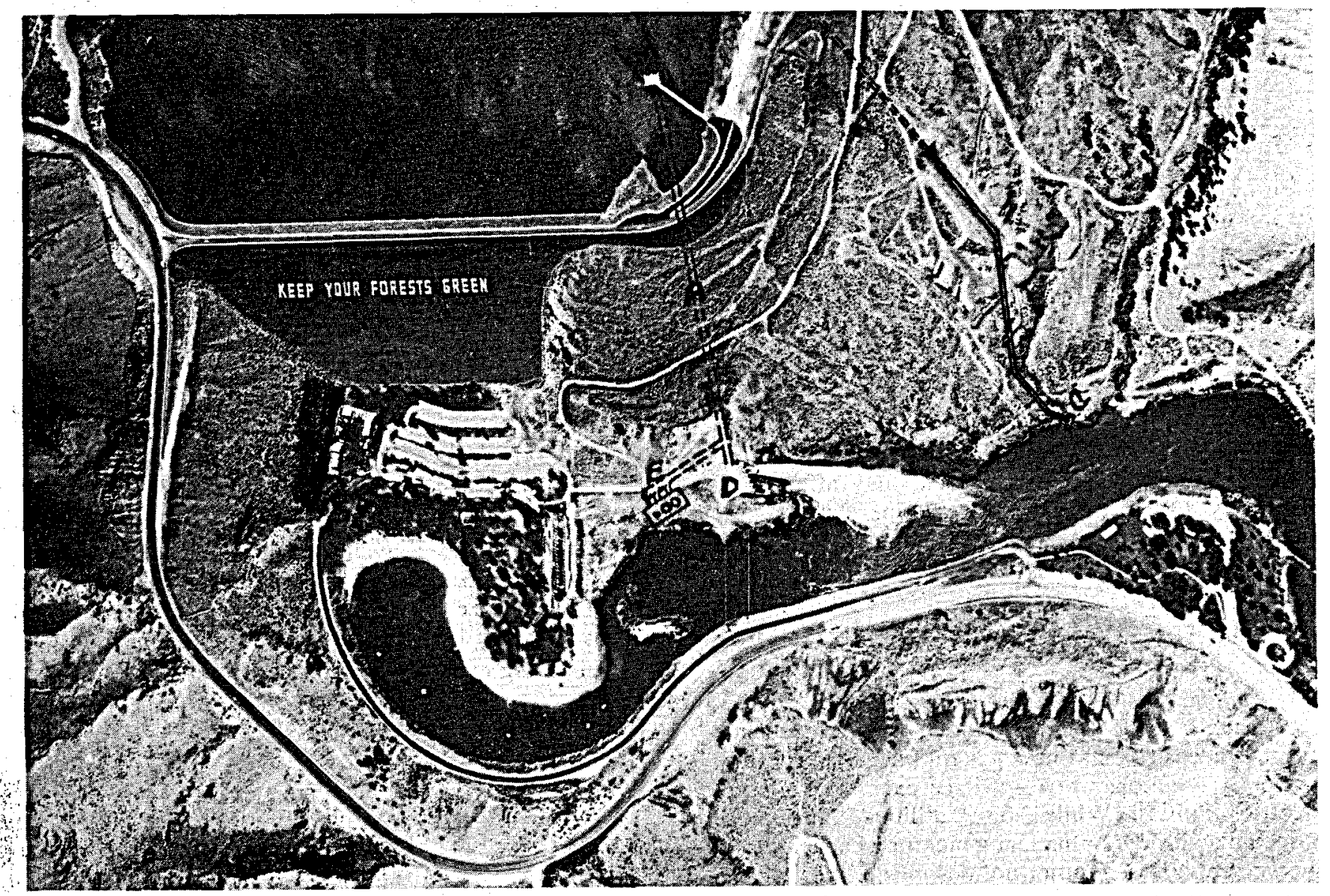

Adding hydroelectric plants to existing dams and retrofitting older facilities will contribute to hydroelectric capacity growth over the forecast period.

chosen either because the existing plant is worn out or because of the greater efficiency of new equipment.

New technologies could make the refurbishment option technically or economically unfeasible. Possible changes in Clean Air Act requirements could necessitate installation of flue gas desulfurization (FGD) equipment in refurbished power plants, making the life extension option less attractive. Furthermore, the life extension option has not been demonstrated to be costeffective. Yet, refurbishment may offer utilities opportunities to avoid constructing high-cost new capacity to meet growing electricity demand.

\section{Cogeneration}

Electricity produced by nonutility cogenerators could also reduce the need for new utility generating capacity over the forecast period. Cogeneration is the com- bined production of both electric power and heat from one energy source. Many industrial processes that use heat can also generate electricity; they can produce both at lower cost than doing each separately. Cogeneration is encouraged by the Public Utility Regulatory Policies Act of 1978 (PURPA, P.L. 95-617), which requires utilities to buy the power offered for sale by cogenerators. FERC requires utilities to purchase power from qualifying cogenerators at mutually agreeable prices or at utilities' avoided costs, that is, the energy and capacity costs a utility avoids by purchasing from the cogenerator. However the cost of generating electricity is increasing.

Possibly as much as 5 to 20 percent of U.S. electricity consumption could be supplied by nonutility sources by the year $2000 .{ }^{61}$ However, the development of extensive noncentralized generation depends on many other factors, including the level of economic activity, relative attractiveness of investment in cogeneration and small power facilities, the mix of industrial activity, the prices of alternative energy sources, and the costs of additional means of generating electricity.

\footnotetext{
${ }^{61}$ Energy Information Administration, Annual Energy Outlook 1984, DOE/EIA-0383(84) (Washington, DC, 1984), p. 153.
} 


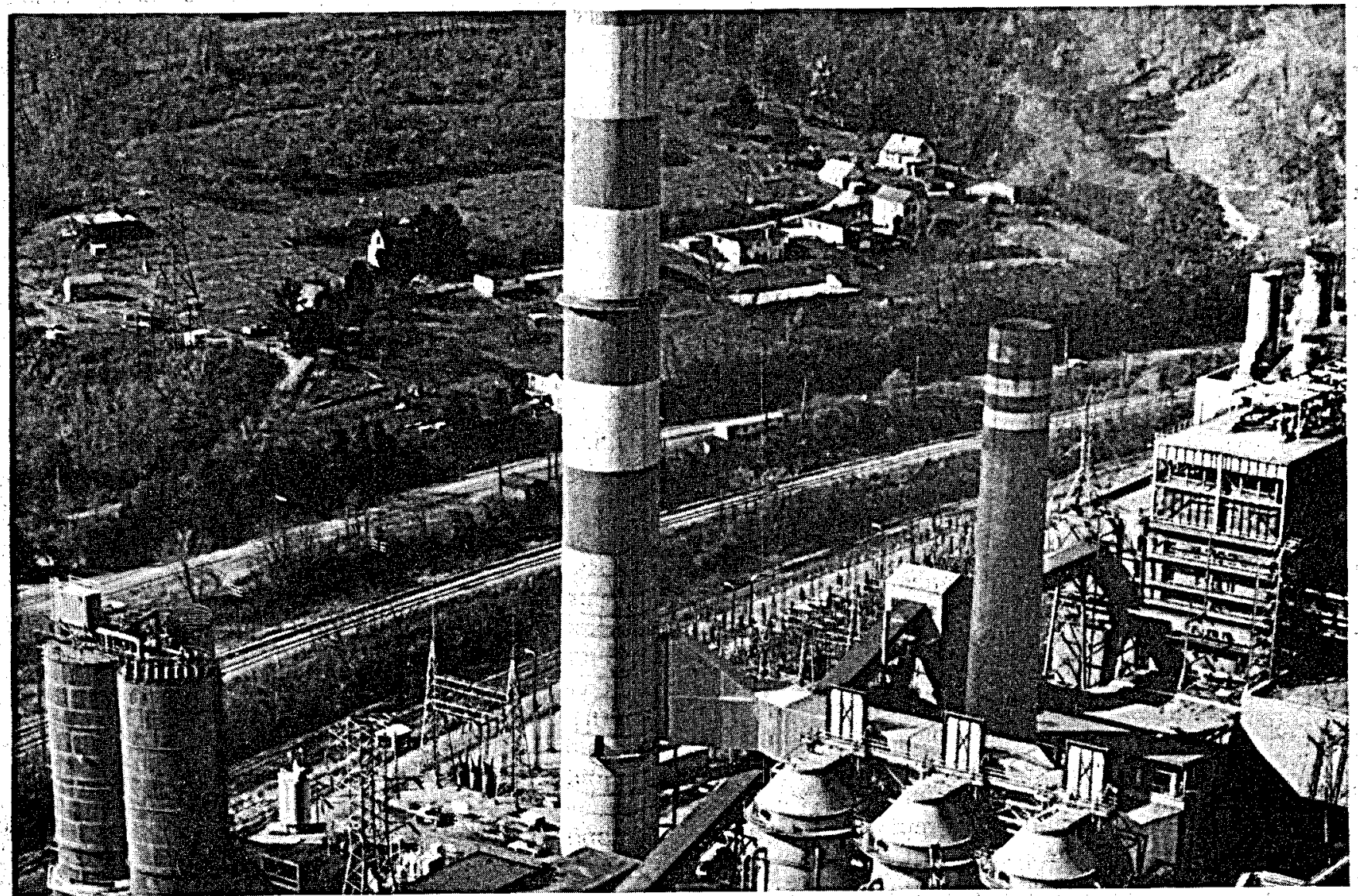

Environmental control equipment occuples a large part of new coal-fired electricity generating plants.

\section{Construction Work in Progress}

Allowing utilities to include some costs of unfinished construction in the current price of electricity could reduce electricity prices in the longer run. Under current regulatory practice, the carrying charges incurred during utility construction are capitalized for later recovery from ratepayers during a plant's operating life. The practice of deferring recovery is known as the AFUDC method, that is, allowance for funds used during construction. An alternative method for recovery is to include the cost of construction work in progress (CWIP) in the current rate base, thereby passing these carrying costs to current ratepayers. Under CWIP, ratepayers pay the carrying costs during the construction period; whereas under the AFUDC method, rates exclude these costs until the plant is in operation.

Accumulating the financing cost until service begins, as done in the AFUDC method, increases the costs of new facilities and causes two problems for utilities: first, the growth of unrecovered financial costs means that greater debt is acquired; and second, because greater risk is associated with greater debt, higher financial costs are incurred. To the extent that CWIP. is included in the rate base as construction is underway, these two costs are reduced and the financing requirements for a project could be lower. The CWIP method offers consumers a "pay as you go" policy for new construction, by which they pay now for benefits received later. Current electricity consumers pay for plants that will benefit future customers. The AFUDC method represents a "pay more later" policy, as consumers do not pay for benefits until they receive them, but at higher cost when new plants do enter service.

Current regulatory rules for CWIP accounts vary among the individual States. Generally, States allow a small percentage of CWIP accounts to enter the rate base. The FERC may permit up to 50 percent of financing costs in the rate base. Proposals have been considered to allow part (above that currently allowed) or all of CWIP in the rate base. These proposed changes could raise prices to consumers initially but reduce costs later, since interest charges that accumulate under current policies would be eliminated. ${ }^{62}$

Concern over "rate shock" could discourage construction of new generating capacity in the future. "Rate shock" refers to the large increases in electricity prices

\footnotetext{
${ }^{62}$ Energy Information Administration, Annual Energy Outlook 1984, pp. 157-159.
} 
caused by introducing expensive new capacity into the rate base. While rate shock is not a nationwide phenomenon, some utilities completing or contemplating high cost new construction could experience negative consequences. Rate shock could result in decreases in electricity consumption, including loss of major industrial customers. On the other hand, public utility commissions (PUC's) could disallow some construction costs from the rate base or delay full recovery of these costs. Both decreases in electricity consumption and PUC disallowances would penalize electric utility investors and could result in utilities facing increasing difficulties in raising investment capital.

\section{Revisions to Federal Tax Law}

Revisions to current tax law, if implemented, could affect electric utilities significantly. $A$ revision proposed by the Department of the Treasury would reduce the corporate tax rate, allow a 10-percent tax deduction for dividend payments, and shorten depreciation schedules. ${ }^{63}$ At the same time, the proposed revision would eliminate the investment tax credit, require amortization of currently expensed interest costs incurred during construction, require repayment of tax benefits associated with the accelerated cost recovery system (ACRS) for depreciation, and impose a minimum corporation income tax of 20 percent. Overall it is believed that the proposal would lower most utilities' Federal tax liabilities and lower electricity prices to ratepayers. However, it could also reduce the cash flow to electric utilities and negatively affect the financial condition of investor-owned utilities.

The effects of the proposal on cash flow would result from the elimination of the investment tax credit, lower tax rates, and from repayments of depreciation benefits. Removal of the investment tax credit would deny a source of cash to uitilities, since current tax benefits are retained by the utilities in deferred tax accounts. Ratepayers recover these tax benefits through lower rates over the long run. Similarly, repayment of ACRS depreciation benefits reduces the deferred tax accounts and cash flow.

Reductions in cash flow could cause difficulties for utilities in securing funds at the most favorable rates. Lending institutions could perceive greater risk associated with utility debt and require higher interest rates to compensate for the additional risk. These higher costs could be passed on to ratepayers as part of the ratemaking process. On the other hand, if electricity prices were lower as a result of the legislation, then demand for electricity could increase. The magnitude of the impacts on electricity prices and cash flow would depend on both the provisions of the legislation and future inflation rates.

\section{Sulfur Dioxide Emissions Control}

Legislation attempting to reduce acid rain could raise electricity prices. The sulfur dioxide $\left(\mathrm{SO}_{2}\right)$ emissions of coal-fired electric utilities are often cited as the principal source of acid rain in eastern North America and southeastern Canada. Numerous proposals to reduce U.S. $\mathrm{SO}_{2}$ emissions have been introduced in Congress. While specifics vary, the proposals typically call for 8 to 10 million ton cutbacks in electric utility in $\mathrm{SO}_{2}$ emissions from 1980 levels (estimated at 16 to 17 million tons) by the early 1990's. Control methods include requirements to install flue gas desulfurization (FGD) equipment or to switch to lower sulfur coal. Some proposals dictate only goals; others specify both goals and compliance methods. Costs of compliance may be borne directly by individual utilities' customers or by both direct customers and the general taxpaying population.

Proposals analyzed by EIA, if passed, would raise electricity costs and impose regional effects on both electricity prices and coal producers. Under the proposals studied, electricity prices would be increased between 3 and 5 percent, as utilities would spend $\$ 10$ billion to $\$ 26$ billion to install FGD equipment, pay higher fuel costs, and incur increased operating and maintenance expenditures. Price increases would be particularly significant in coal dependent regions bordering or east of the Mississippi River. It is likely that electricity demand would be reduced as a result of the expected higher prices. Depending upon the requirements of the specific proposal enacted, coal markets could be significantly affected, with lowsulfur coal regions of the country gaining if coal switching is allowed (Central Appalachia and the Northern Great Plains, for example) and less expensive high-sulfur coal regions maintaining markets if FGD installation becomes mandatory (such as Northern Appalachia and the Midwest).

\section{Disposal of Spent Nuclear Fuel}

Problems of disposal of spent nuclear fuel from commercial power plants could also increase utility costs over the forecast period if satisfactory temporary storage methods are not found. The Nuclear Waste Policy. Act of 1982 (P.L. 97-425) directs the U.S. Department

\footnotetext{
1985).

${ }^{63}$ Executive Office of the President, The President's Tax Proposals to the Congress for Fairness, Growth, and Simplicity (Washington, DC, May
} 
of Energy (DOE) to develop permanent disposal sites for spent fuel from commercial nuclear power plants. Three potential sites for the first repository have been identified and are currently being analyzed: (1) in bedded salt in Deaf Smith County, Texas; (2) in basalt on the Hanford reactor site near Richland, Washington; and (3) in volcanic tuff in the Yucca Mountains on the boundaries of the Nevada Test Site, in Nevada. Development of permanent disposal sites is not expected to influence siting or operations of commercial nuclear power plants over the 1985-1995 forecast period. Actual disposal of spent fuel will not begin until 1998, and costs of the disposal program are already being imposed on nuclear power plant operators via a 1-millper-kilowatthour fee for all electricity generated by nuclear plants.

Until 1998 utilities must be able to store all the spent fuel they generate. Some new temporary storage for spent nuclear fuels must be found during the forecast period, or some individual utilities may face significantly higher costs. Some utilities' storage pools may reach capacity and be unable to accommodate all the spent fuel at current operating rates until 1998. These utilities would then be forced to develop new pool facilities on site, to transport spent fuel to other sites, to develop alternative storage techniques (rod consolidation or dry storage), seek temporary Federal storage, or cease operations altogether. All alternatives appear expensive. Spent fuel storage pools are very expensive; trans- portation is considered hazardous and requires the availability of alternate storage facilities; new storage technologies, such as dry storage in casks, are not yet proven or licensed. Stopping operations implies substitution of higher cost fossil-fueled electricity for less expensive nuclear power.

\section{Conclusion}

The projections in Chapter 4 assume the continuation of recent trends. Chapter 5 presents specific factors that may modify these trends over the forecast period. In addition, efficiency gains may be found as a result of reducing Federal and State regulation of electric utilities and by increasing the role of the competitive marketplace in guiding electric utility operations. Increased regulatory disallowances of new power plants from the rate base as unneeded excess capacity may discourage utilities from building new capacity in anticipation of future demand. Finally, increases in electric utility diversification into other fields, such as energy development or real estate, may signal reduced attractiveness of electric power investment and decreased growth in electric power services. These factors, plus many other known, suspected, or yet to be discovered, will undoubtedly influence electric power over the next decade. 


\section{,}

, 
Appendix A

TECHNOLOGIES

OF ELECTRIC

POWER

GENERATION 


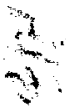




\section{TECHNOLOGIES OF ELECTRIC POWER GENERATION}

\section{Principles of Electric Power Generation}

According to the laws of physics, energy cannot be created or destroyed; it can only be converted from one form to another. The conversions needed to yield useful energy for any particular application vary with the beginning form of energy and the form of energy desired. For electricity, present-day technology almost always relies on two basic conversion devices: the electric generator and the prime mover.

\section{The Electric Generator}

The electric generator is a device for converting mechanical energy to electric energy. The process is based on the relationship between magnetism and electricity. When a wire or any other electrically conductive material moves across a magnetic field, an electric current occurs in the wire. The large generators used by the electric utility industry have a stationary conductor. A magnet attached to the end of a rotating shaft is positioned inside a stationary conducting ring that is wrapped with a long, continuous piece of wire. When the magnet rotates, it induces a small electric current in each section of wire as it passes. Each section of wire constitutes a small, separate electric conductor. All the small currents of individual sections add up to one current of considerable size. This current is what the utility uses to fill the public's demand for electric power. Figure $A 1$ is a rudimentary illustration of an electric generator.

\section{The Prime Mover}

The prime mover is a turbine, engine, waterwheel, or other machine that drives the generator. Most prime movers producing electricity today are turbines, a se- ries of blades mounted on a shaft against which fluids are forced, rotating the shaft connected to the generator. The turbine converts the kinetic energy of a moving fluid (either liquid or gas) to mechanical energy (Figure A1). The fluids most commonly used in turbines are steam, hot air or combustion products, and water.

\section{Steam Turbines}

With fossil fuels--coal, for example--the heat produced by burning fuels must be transferred to a moving fluid that is cleaner than the combustion gases to reduce corrosion of the turbine blades. The fluid of choice is usually steam. In a steam turbine, the coal or other fuel is burned to heat water in a boiler, and the resulting steam then turns the blades of the turbine.

The steam turbine is by far the most common type of turbine used in electricity generation; steam turbines provide economical baseload electricity generation. In 1984 , steam turbines produced over 85 percent of the electricity generated in the United States.

\section{Gas Turbines}

In a gas turbine, combustion gases produced when the fuel burns pass directly through the turbine. This cycle, in using combustion gases directly, is fundamentally different from that of the steam turbine where the combustion heat is transferred to steam, which then serves as the turbine's working fluid. Gas turbines are commonly used in utility peaking units.

\section{Comblned-Cycle Turblnes}

The gas turbine, typical of peaking units, has lower efficiency than the steam turbine used for baseload power. Inefficiency is reduced when the gas turbine is coupled with a steam turbine in a "combined-cycle" unit (Figure A2). At about 1,900 degrees Fahrenheit, the combustion gases of a gas turbine are much hotter than the steam used in a steam turbine $(1,000$ degrees Fahrenheit). Even after they have passed through the 
Figure A1. Coal-Fired Steam Electriclty Generation

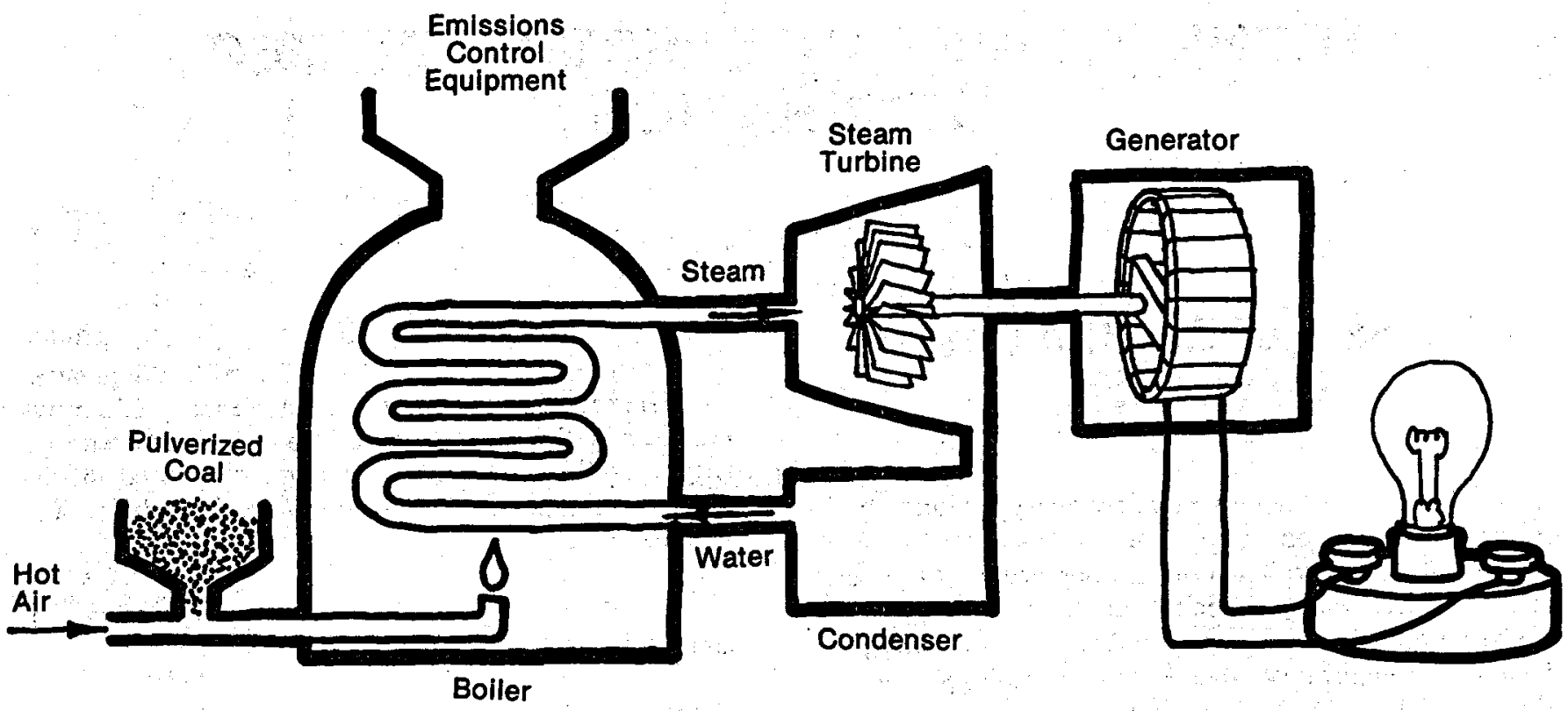

Source: Electric Power Research Institute, Electricity, Today's Technologies, Tomorrow's Alternatives (1982), p. 30.

turbine, these combustion gases are still about 1,000 degrees Fahrenheit. The combined-cycle system moves the hot gases (which have already spun one turbine generator) into a "waste heat recovery" steam boiler, where they heat water in the boiler tubes to produce steam that can produce electricity by running a second generator. Two generators are able to produce electricity from one initial fuel input.

\section{Hydroelectric Turbines}

Hydroelectric power is the eventual product of a process in which flowing water is used to spin a turbine connected to a generator. The two basic types of hydroelectric systems are those based on falling water, and those based on the natural river current. In the first system (Figure A3), water accumulates in reservoirs (or forebays) created by damming natural watercourses. This water then falls through conduits (called penstocks) and is pushed against the turbine blades. In the second system, called a run-of-the-river system, the force of the river current (rather than falling water) pushes the turbine blades. Run-of-the-river systems do not usually have reservoirs and cannot store substantial quantities of water. Power production from these systems depends on seasonal changes and stream flow.
A third kind of hydroelectric generation is referred to as a "pumped storage" system. This method uses electricity produced at other baseload generators most efficiently left running even during off-peak hours to pump water from a lower to higher reservoir. Later, the water is allowed to flow back down through the turbine-generator during periods of high electricity demand. In effect, pumped storage systems save a portion of surplus electricity produced off peak by baseload generators.

Generating electricity from water power has several advantages. The major advantage is that water resources are renewable. In addition, because there is no fuel combustion, there is little air pollution in comparison with fossil-fuel plants and limited thermal pollution in comparison with nuclear plants. Like other energy sources, hydroelectric generation has its limitations. These include environmental impacts caused by damming rivers and streams, which affects the habitats of the local plant, fish, and animal life.

\section{Wind Turbines}

Two basic types of wind turbines are on the market today--horizontal-axis and vertical-axis turbines. The horizontal- axis rotor turbines, with the rotor-shaft axis parallel to the ground, is the more prevalent. It consists 
Figure A2. Combined-Cycle Electricity Generation

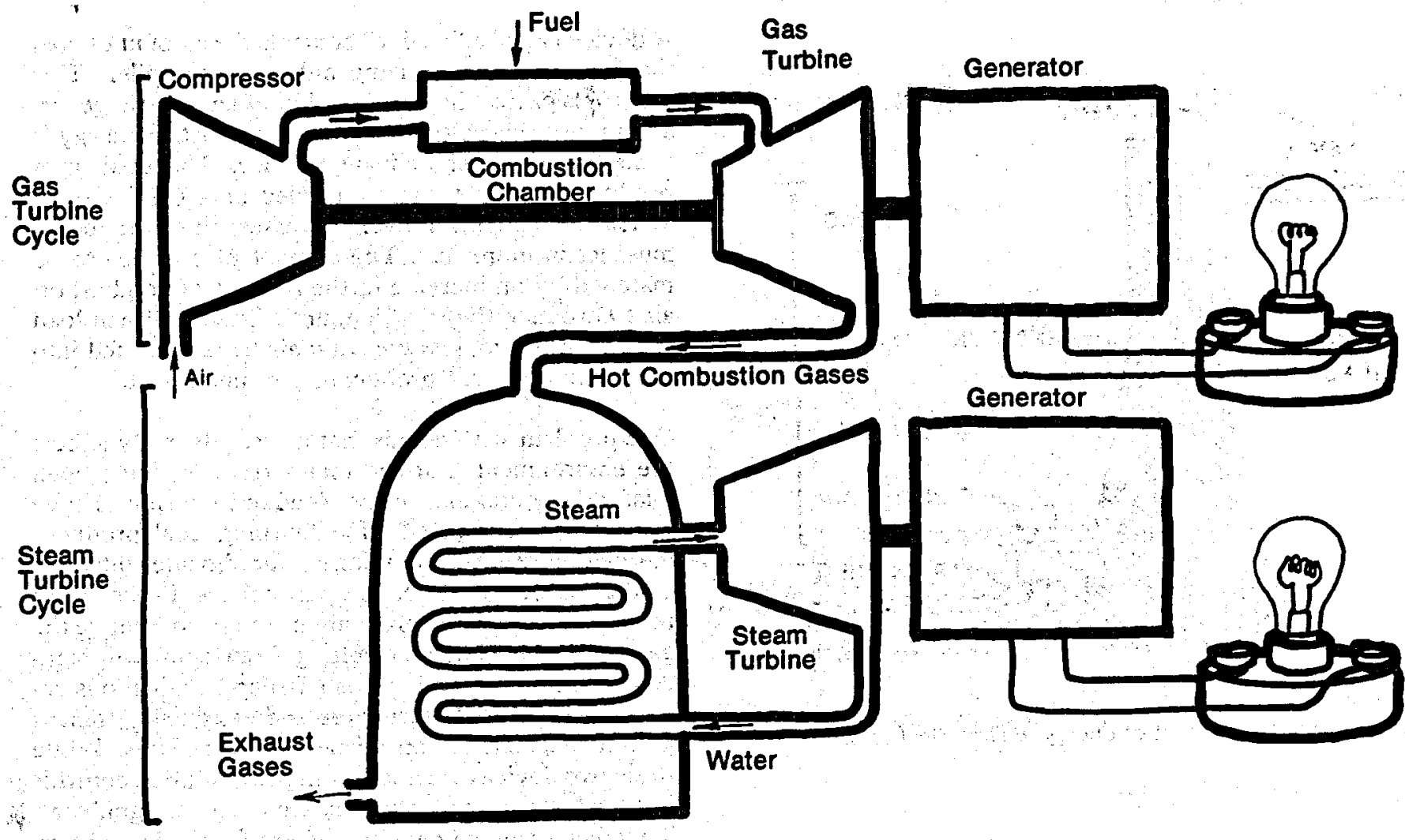

Source: Electric Power Research Institute, Electriclty, Today's Technologies, Tomorrow's Alternatives (1982), p. 31.

of propellers connected by gears that transfer the power from the rotation of the blades to a generator. All of the generating machinery is mounted at the top of a tower. Vertical-axis rotor turbines are characterized by eggbeater-shaped blades attached to a vertical shaft. The vertical-axis rotors, which are the principal competitor of the propeller-type systems, can accept wind from any direction and therefore do not require mechanisms and controls to turn the rotor into the wind. In addition, gears and generators of vertical-axis turbine machines are ground-mounted, minimizing tower requirements and permitting ground access for repair and maintenance.

\section{Diesel Generators}

A diesel generator is actually a large internalcombustion engine connected to the shaft of an electric generator. This engine, rather than a turbine, provides the mechanical energy necessary to spin the generator for power production. Diesel generators can be transported easily and installed on very short notice. They also begin generating power the moment they start, which is ideal for satisfying peak demand. Like gas turbines, diesel generators generally supplement large baseload units during periods of peak demand. Although a number of units can be connected (either mechanically or electrically) to provide large blocks of power, the modest capacity of diesel units, together wth high fuel costs, remains a drawback for large-scale generation.

\section{Fuels for Electricity Generation}

\section{Nonrenewable Fuels}

Nonrenewable fuels cannot be replaced once used. The nonrenewable fuels used most often in generating electricity are the fossil fuels-coal, oil, and natural gas--and uranium.

\section{Fossill Fuels}

Coal, oil, and natural gas are called "fossil" fuels. They are the remains of plants and animals that lived on earth hundreds of millions of years ago. Fossil fuels are used to generate about 75 percent of all the electricity in the United States. 
Figure A3. Hydroelectric Power System With Reservoir

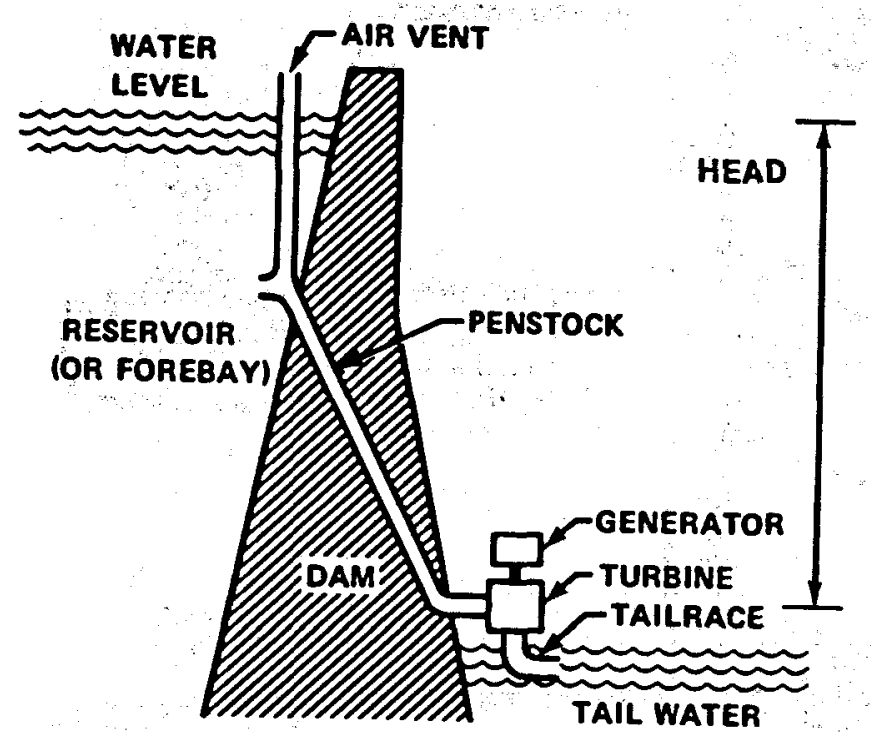

Source: U.S. Department of Energy, Energy Deskbook

(June 1982), p. 188.

A modern fossil-fueled steam electric power plant is large and complex (Figure A1). A typical large plant contains two to four generating units with capacities ranging from 30 to 1,300 megawatts per unit. Each plant includes fuel-handling facilities, boilers, turbines, generators, control stations, and a condensing water supply. Where coal is burned, pulverizers, coal storage, and solid-waste disposal facilities are also required. The boiler structures associated with the largest of these plants may be 20 stories high; an entire plant, including areas for coal storage, ash disposal, and cooling ponds, may cover several hundred acres. Boilers can be designed to burn any combination of these fuels.

Coal is our most plentiful fossil energy resource. Coal is burned primarily in steam turbine baseload plants. When coal is delivered to a coal-fired power plant, it is first placed in a storage area. When it is needed to generate electricity, it is transported to a "crusher," a machine that reduces the size of the coal pieces to an average of three-quarters of an inch. Next, the coal is transported to a pulverizing mill where it is ground to the consistency of fine powder for efficient burning. It is then mixed with air and burned in the boiler. The heat from the burning coal is transferred to water that circulates in a closed cycle in pipes around the boiler, changing the water to steam. The steam is used to turn the turbine connected to a generator. After passing through the turbine, the steam is condensed to water and recirculated to the boiler for further use.

A device called a "feeder" controls the amount of coal that enters the pulverizing mill and the boiler. This control is critical in the operation of an electric generating unit because the generation of electric energy is a matter of rather delicate balance. The coal must produce the exact energy needed at a precise time. When demand for power increases, the coal feeder must let in more fuel. The amount of coal has to be matched by an increase in the amount of combustion air to produce the right amount of steam. When load is being reduced, less coal and air have to be fed into the boiler to avoid producing too much heat.

One problem with coal is that its use adversely affects the environment. Surface mines result in huge open pits, and the sites must be restored once the mines have been exhausted. In addition, burning coal produces various emissions, including sulfur dioxide, nitrogen oxides, carbon dioxide, and particulates. Processes to remove pollutants before combustion or to remove the gases and particulates resulting from combustion increase the cost of using coal. Federal regulations require sulfur dioxide scrubbers and extremely efficient particulate controls on all new power plants. While these two devices are not the only air pollution controls installed at power plants, they are the most significant. Together, they may add anywhere from 20 to 25 percent to the cost of building a power plant.

The control of sulfur emissions from power plants is primarily by use of stack gas scrubbers. Stack gas scrubbing is a process in which the gases that result from coal combustion are passed through tanks containing a material, such as lime or limestone in a water slurry, that captures and neutralizes the sulfur dioxide. The sulfurous gases cannot escape into the atmosphere because they react with the lime or limestone solution to form a thick sludge. Scrubbers clean between 80 and 90 percent of the sulfur dioxide from flue gases. Particulate matter is removed from the combustion gases primarily by cleaning the gas with an "electrostatic precipitator" or filtering it in a "baghouse." When the gases from burning coal are passed through an electrostatic precipitator, the particles of dust and ash are given an electrical charge. This charge allows the particles to be drawn off, as if by a magnet, and collected rather than discharged into the atmosphere. $A$ baghouse on a power plant operates in a manner very similar to a household vacuum cleaner. The combustion gases are passed through a series of filter bags that trap the particles of dust and ash. Periodically, the bags are shaken in such a manner that the material collected falls into a bin and is removed.

Generating electricity with oil and natural gas is far less complex than with coal. Delivery of oil and gas is less difficult; both oil and gas are often relatively unobtrusively delivered by pipeline. Storage area requirements are smaller; natural gas is typically not stockpiled at all. Neither oil nor natural gas requires 
the precombustion preparation required of coal, eliminating the need for cleaning, crushing, pulverizing, and other preparatory steps. Combustion involves the far simpler process of injecting the fuel, essentially in the same form in which it is delivered, into the boiler. Finally, neither oil nor natural gas incurs the disposal costs for removing emission or postcombustion waste products incurred by coal. Despite all these advantages, however, the much higher cost of both oil and natural gas discourages their wide use in baseload plants today, and oil or natural gas generation is most commonly used to meet intermediate and peak loads.

\section{Uranium}

Nuclear energy was the second largest contributor of electricity generation in 1984, 13 percent. At the end of 1984, 86 nuclear reactors were operating in the United States. 64

In a fossil-fuel power plant, coal, oil, or gas burned in a furnace provides heat to change water to hightemperature steam. In a nuclear power plant, the furnace is replaced by a reactor containing a core of nuclear fuel, primarily enriched uranium. Heat produced in the reactor by splitting uranium atoms is used to make the steam. The steam then passes through a turbine generator to generate electricity, as in a conventional coal-fired generating plant. The only real difference between nuclear and fossil-fuel power plants is in the method of heating the water to make the steam.

In nuclear power reactors, the heat that accompanies the process of splitting atoms, fission, is used to produce high-temperature steam, which is used to generate electricity. In nature, uranium consists principally of uranium-238 ( 99.3 percent) and uranium-235 (0.7 percent). The uranium-235 nucleus is quite unstable and can be split or "fissioned" by hitting it with a neutron. When hit by a neutron, the uranium-235 nucleus fissions--splits into two or more new elements. This process releases heat, radiation, and two or three more neutrons. Under controlled conditions, these other neutrons can strike other uranium-235 atoms and cause them to split, releasing more neutrons, splitting more atoms, and so on. Thereby, continuous fission can take place--a chain reaction.

Because the energy content of nuclear fuel is extremely high, just a little can go a very long way. In fact, the fission of just one pound of nuclear fuel (as typically burned in a U.S. reactor) releases as much energy as the combustion of about 3 million pounds of coal. This high potential for energy production makes full use of nuclear fuel particularly desirable.

The principal nuclear power reactors presently in commercial use in the United States are light-water reactors (LWR's). These reactors have four major components: fuel rods, which contain pellets of uranium fuel; a mod- erator, which slows down the neutrons emitted during fission; control rods, which contain substances that absorb neutrons readily and therefore control the rate of heat production; and a coolant, which both cools the fuel rods and carries their heat to another part of the power plant, where it is used to produce power. Ordinary water (sometimes referred to as "light water" to differentiate it from "heavy water" containing neutrons used in other types of reactors) serves as both the moderator and the coolant in LWR's. The fuel rods are arrayed in assemblies that allow the water to circulate between the rods. Groups of rod assemblies make up the reactor core, and the entire core is covered by the water contained in the reactor vessel:

There are two major types of LWR's, the pressurized water reactor (PWR) and the boiling water reactor (BWR), as illustrated in Figures A4 and A5. They differ basically in how they use the heat carried by the cooling water to drive the steam turbine.

\section{Figure A4. Pressurized Water Reactor (PWR)}

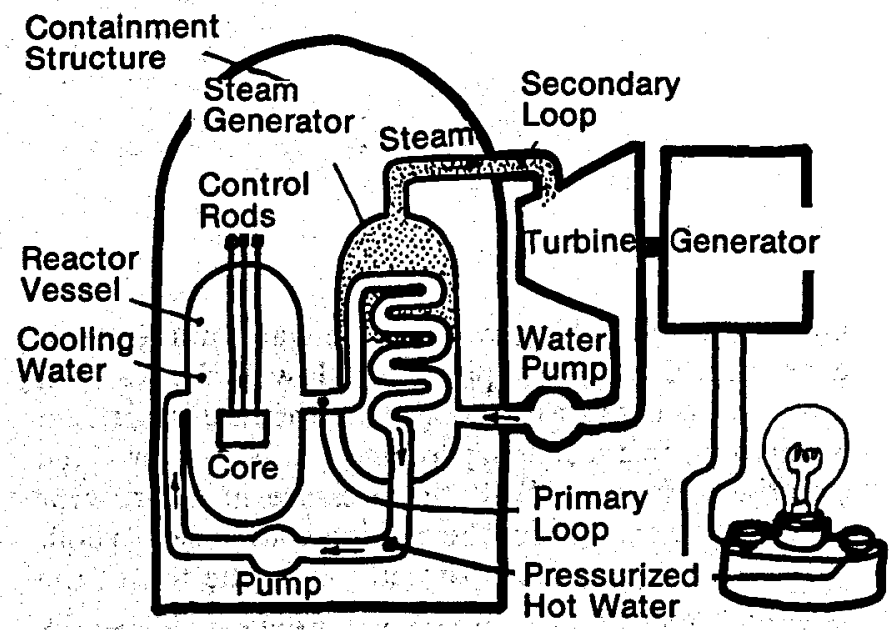

Source: Electric Power Research Institute, Electricity, Today's Technologies, Tomorrow's Alternatives (1982), p. 34.

In the PWR, the heat generated by the fuel rods is transferred to the cooling water, which circulates through the core assembly at high pressure. The heated water flows from the reactor vessel in a primary loop that passes through a steam generator, where its heat

\footnotetext{
${ }^{64}$ Energy Information Administration, Monthly Energy Review, DOE/EIA-0035(84/12) (Washington, DC, December 1984 ), pp. 78 and 87.
} 
Figure A5. Boiling Water Reactor (BWR)

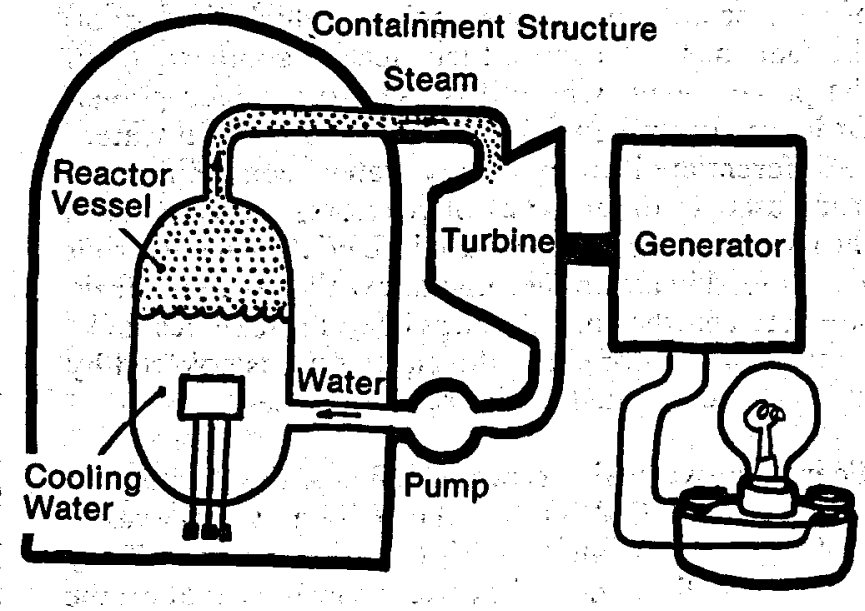

Source: Electric Power Research Institute, Electricity, Today's Technologies, Tomorrow's Alternatives (1982), p. 34.

moves through tubing walls to the water in the steam generator. Because the pressure is lower, the water in the steam generator then boils, and the resulting steam is run through a secondary loop to a turbine to produce electricity. In the BWR, the pressure in the reactor vessel is low enough for the cooling water itself to boil. The steam is then piped directly from the top of the reactor vessel to a steam turbine, where it acts as the turbine's working fluid.

\section{Renewable Fuels}

Renewable resources--sun, wind, rivers, heat from within the earth, organic wastes produced by natural and technological processes--are energy resources that are constantly replenished. Technology and cost are both obstacles to their expanded use, however.

\section{Hydroelectrlc Power}

Hydroelectric power, described in the section on hydroelectric turbines, is currently the leading renewable energy source used to generate electric power. In the early 1980's, hydroelectric power consistently av- eraged almost 13 percent of total U.S. electricity generation.

\section{Geothermal Power}

Geothermal power comes from heat energy buried deep beneath the earth's surface. Most of this heat is concentrated at depths beyond the reach of current drilling methods. But in a few U.S. areas, magma (molten rock) from these deep regions approaches the earth's surface through faults and fractures and produces steam that can be run directly through a conventional steam turbine generator to produce power.

Geothermal steam resources are quite limited. The Geysers, about 90 miles north of San Francisco, is currently the largest geothermal generating plant producing electricity in the United States. Because of their inherently slow startup time, U.S. geothermal steam plants are operated as baseload units.

Environmental problems are associated with the use of geothermal energy. The steam must be vented to clear the lines and to test or protect wells. This venting releases quantities of hydrogen sulfide, ammonia, and radon, and can be noisy unless adequately muffled. Dissolved minerals in the steam create corrosion problems for pipes, valves, and the turbine.

\section{Wind Energy}

Electric utilities are playing a major role in advancing wind power development, not only by conducting their own projects but also by using wind-generated electricity others have produced. California utilities lead the world in contracting to purchase power from wind farms and individual wind turbines. Contracts have been signed that will result in more than 1,000 megawatts of generation in wind farms.

Wind generation is expensive, although the wind itself is free. Despite the low operating costs for wind systems, the capital costs of wind turbines are high. Costs of wind-generated electricity are currently two to three times the cost of electricity generated by conventional thermal plants. These costs are the greatest barrier to the use of wind systems; costs must be reduced to make wind energy competitive with other resources. Another major problem associated with wind generation is the intermittent nature of the wind; wind energy must be used to produce electricity when the wind blows, not when the electricity is needed, affecting power availability. Average wind speeds below about 8 miles per hour are not sufficient to produce power economically with the present technology.

\section{Solar Power}

Solar power is the conversion of sunlight directly into electricity or, indirectly, into heat that is converted 


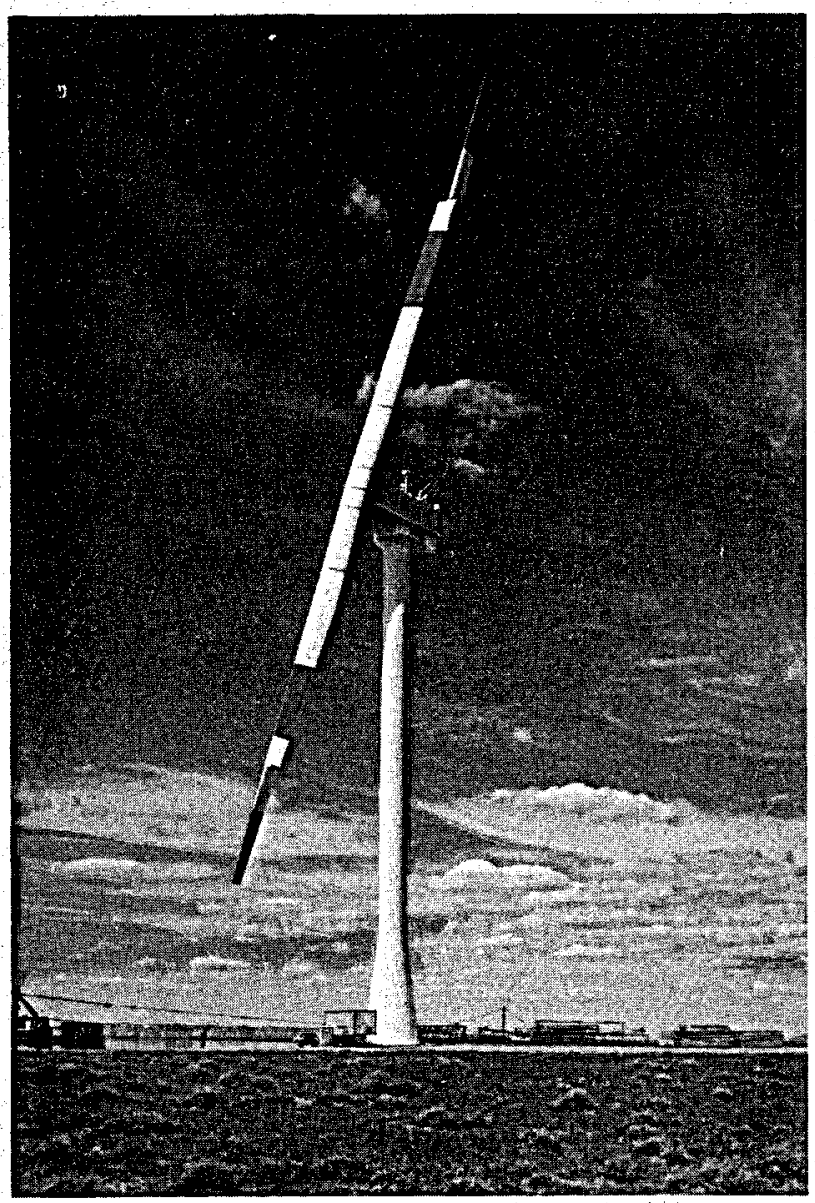

This Boeing 2.5.megawatt horizontal axis wind turbine illustrates new technologies in electricity generation.

into electricity. Photovoltaic conversion generates electric power directly from sunlight rather than using the sun's heat. The unit that generates electricity is a photovoltaic, or solar, cell made from a semiconductor material, such as silicon. The first 1-megawatt commercial photovoltaic power plant to be built by a public utility, the "PV-1" unit in California, is now generating electric power as well as important performance data.

Another promising indirect method of converting sunlight into electricity is a solar-thermal electric generating station, which uses the heat of the sun to produce steam to drive conventional steam or gas turbines. Solat thermal includes five technologies: solar ponds, hemispheric bowls, parabolic troughs, parabolic dishes, and central receivers. Except for solar ponds, the concept is uniform: sunlight striking a flat or shaped mirror is focused on a central point and heats a working fluid (steam or air used to drive a turbine). Solar ponds are large bodies of water used to collect and store lower temperature solar energy (up to 200 degrees Fahrenheit). The absorbed and stored heat is then run through a heat exchanger to create turbine steam. The large volume of water enables the system to provide thermal or electric energy at all times.

The central receiver concept is now considered the best for economic solar-thermal conversion; the light reflected from each mirror is focused on a thermal receiver at the top of a tower. The heat produced by the concentrated light then transfers from the thermal receiver to the working fluid, which is piped down the tower to a turbine for electricity generation. Central receiver technology has been successfully demonstrated at the pilot-plant level by Solar One, a 10-megawat plant in California. Solar One, in its first year of operation, produced over 2 million kilowatthours of electricity.

The main block to solar-thermal electricity is the same as for the other solar power options: it is expensive, both to construct generating systems and to ensure their reliability (the ability to provide power whenever it is needed). The central receiver system, which is expected to be the lowest cost solar alternative for utility use on a large scale, is still considerably more expensive than coal or nuclear power generation. In addition, the fact that the sun shines only during the day, and very little on some days, means that a solar generating station can operate only about one-half to one-third of the time. In addition, the energy cannot be stored.

\section{Biomass}

Biomass is generally defined as organic material that can provide heat. Biomass includes plants, marine algae, crop and forest leftovers, garbage and trash, and manure. All of these substances contain chemical energy. When they decay or are burned, they release their chemical energy as heat useful for electricity generation. Biomass systems are the only fuel-based renewable energy source, allowing the fuel energy to be stored until electricity is needed. Consequently, there are no direct energy storage problems.

Biomass-based electricity production is derived from the combustion of solid, liquid, or gaseous biomass fuels to create steam to run a turbine. Biomass resources can be used to replace fossil fuels in utility boilers. Currently, a substantial amount of biomass is used at electric utilities as a fuel source for generating electricity. To date, several electric generating plants have been built using wood as a primary fuel. Several other plants are now generating electricity from such biomass materials as refuse, tire chips, and sugar cane.

\section{Future Generating Options}

Technologies such as conventional fossil fuel, conventional nuclear, hydroelectric, and dry steam geothermal supply today's electric power needs. In contrast, the options discussed in the next section are not yet commercially available. Currently, the energy and costs they require are greater than the energy and cost savings they yield, but their potential may be great. 


\section{Clean Coal Combustion}

New technologies are being developed to improve the way coal is used, either by burning it more cleanly, or by converting it to liquid or gaseous fuels at a competitive cost.

The Integrated Gasification/Combined-Cycle (IGCC) power plant promises to produce pollution emissions rates an order of magnitude lower than current requirements for new conventional coal-fired power plants. The combined-cycle design offers greater efficiency than traditional technologies, so fuel costs will be lower. In addition, the modular nature of combined-cycle units may allow utilities to add generating capacity in smaller increments to meet actual electricity demand growth, thereby preserving utility capital funds and reducing utility investment.

The industry's first IGCC, the 100-MW Cool Water plant (located in California's Mojave Desert), began operation as a demonstration project on June 24, 1984, and is expected to begin commercial operation in January 1990. The plant's environmental emissions have met the Federal new-source performance standards and the State's strict pollution-control laws. Southern California Edison Co. (SCE), as the only utility in a complex consortium of partners, played an integral role in developing the plant. SCE plans to purchase this facility after the initial testing and operation demonstration period ends in 1989.

Fluidized-bed combustion (FBC) reduces harmful combustion emissions by controlling and modifying the various chemical reactions that are present during coal burning. Gases that might pollute the air or have other undesirable affects are prevented from forming or are converted to substances that do not pollute the air.

In .FBC, the crushed coal burns in a "fluidized-bed," a concentrated suspension of crushed limestone particles in a flow of hot gas, usually air. Although the bed is composed almost completely of solids, the movement of hot air causes the particles to boil like a turbulent fluid. As the coal burns, the limestone reacts chemically with the sulfur oxides normally created during coal combustion to form calcium sulfate. This waste is collected in the form of a dry, granular solid. Thus, because the sulfur oxides that can threaten air quality are captured during the actual coal burning, these systems do not require expensive cleanup of stack gases, although they still produce waste that must be disposed of properly.

Two types of FBC are atmospheric fluidized-bed combustion (AFBC), and pressurized fluidized-bed combustion (PFBC). With AFBC combustion the boiler operates at atmospheric pressure and boiler size is approximately the same as a conventional boiler. The advantages of AFBC over the conventional boiler design include elimination of a scrubber, more fuel flexi- bility, and inherently low nitrogen oxide production. The PFBC operates at high pressure, 10 or 15 atmospheres. This means the boiler can be much smaller, one-fifth the size of a conventional boiler, and can be built in a supplier's factory and shipped to the utility's site on a barge, eliminating a substantial amount of field construction. Operation of the PFBC at high pressure makes it possible to integrate the boiler into a combined-cycle system and achieve higher efficiencies.

To date, three utilities have asked the Federal Government for money to retrofit aged power plants to burn coal in PFBC boilers. Several other utilities have invested millions of dollars in the construction of three AFBC demonstration plants, ranging in size from 100 to 160 megawatts. Ultimately, as with most new technologies, the future of FBC systems will depend on how their performance and economies compare with those of other systems.

\section{Wave Energy Conversion}

The wind transfers some of its kinetic energy to the surface of the ocean in the form of waves. The rise and fall of the waves can be converted into hydraulic pressure by mechanical compression devices, and the pressure can drive a turbine generator to produce electricity. However, wave motion is intermittent and consequently unreliable for baseload power generation. Wave systems are expensive and present major structural problems.

With one such conversion device, the waves push against a series of plates that flap as the water moves. The mechanical motion of the plates, which are hinged to small mechanical pumps, force the working fluid through the turbine, generating electricity. Another device consists of a line of floating rafts, with mechanical pumps located at the joints that connect them. As the rafts move up and down, the pumps compress the working fluid that spins the turbine generator to produce electricity.

\section{Ocean-Thermal Energy Conversion}

Ocean-thermal energy conversion (OTEC) generates electricity by exploiting the temperature difference between the ocean's relatively warm surface water, which is heated by the sun during the day, and the cold water more than a thousand feet below the surface.

One typical version of an OTEC plant consists of a cylinder about 800 feet in diameter and 1500 feet high that floats vertically, with the top just above the sur- 
face of the water. A low-boiling- point gas, such as ammonia, is pumped to the bottom of the cylinder, where it is condensed to liquid form by the cold water. The liquid is then pumped back to the surface where the heat of the surface water causes it to boil. The expanding gas turns a turbine generator to produce electricity. Unfortunately, the plant size, temperature difference, and depth requirements necessary for a reasonably efficient OTEC system imply development of extremely large plants far from land. The costs of meeting these requirements currently prevent the commercial exploitation of OTEC generation.

\section{Magnetohydrodynamics}

Magnetohydrodynamics (MHD) produces electricity directly from heated gases, rather than by the mechanical spinning of a generator. High- temperature ionized gases pass through a powerful magnetic field to produce a flow of electrons in the gases. This flow of electrons, when collected and transferred to an outside circuit, constitutes an electric current. While the technology is feasible, many problems remain, such as durability of some equipment, reliability of electrodes, and performance of superconducting magnets. 


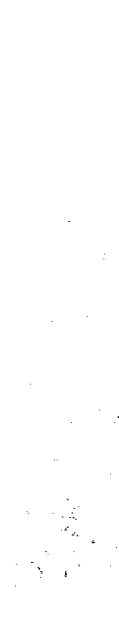




$\left|\begin{array}{l|l|} & \begin{array}{l}\text { Appendix B } \\ \text { HISTORICAL } \\ \text { STATISTICS OF } \\ \text { THE ELECTRIC } \\ \text { UTILITY } \\ \text { INDUSTRY }\end{array} \\ & \\ & \end{array}\right|$




\section{HISTORICAL STATISTICS OF THE ELECTRIC UTILITY INDUSTRY}


Table B1. Historical Statistics of the Electric Utility Industry, 1902-1984

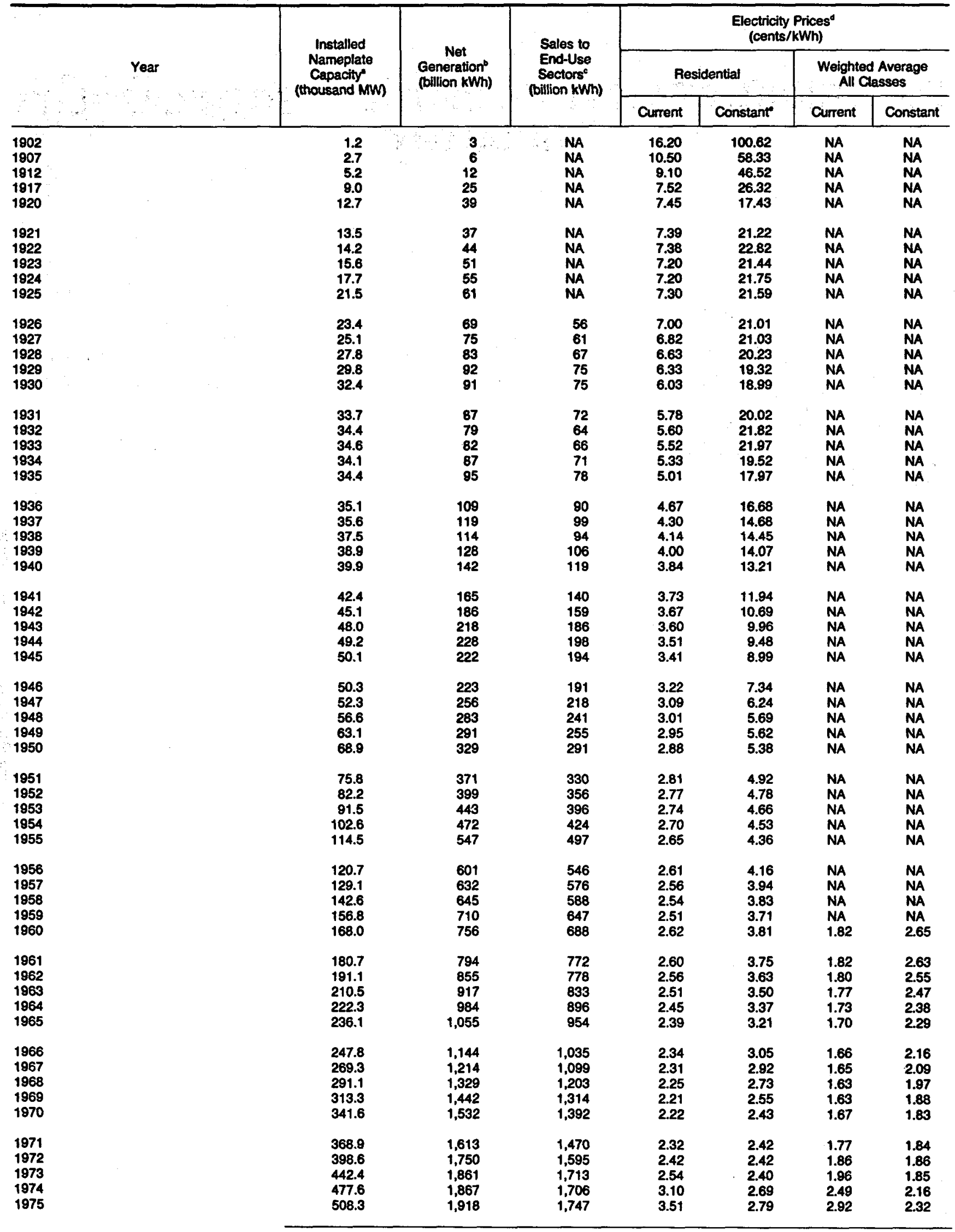


Table B1. Historical Statistics of the Electric Utility Industry, 1902-1984 (Continued)

\begin{tabular}{|c|c|c|c|c|c|c|c|c|}
\hline & \multirow{3}{*}{ Year } & \multirow{3}{*}{$\begin{array}{c}\text { Installed } \\
\text { Nameplate } \\
\text { Capacity } \\
\text { (thousand MW) }\end{array}$} & \multirow{3}{*}{$\begin{array}{l}\text { Net } \\
\text { Generation' } \\
\text { (billion kWh) }\end{array}$} & \multirow{3}{*}{$\begin{array}{l}\text { Sales to } \\
\text { End-Use } \\
\text { Sectorse } \\
\text { (billion kWh) }\end{array}$} & \multicolumn{4}{|c|}{$\begin{array}{l}\text { Electricity Prices } \\
\text { (cents/kWh) }\end{array}$} \\
\hline & & & & & \multicolumn{2}{|c|}{ Residential } & \multicolumn{2}{|c|}{$\begin{array}{c}\text { Weighted Average } \\
\text { All Classes }\end{array}$} \\
\hline & & & & & Current & Constant & Current & Constant \\
\hline $\begin{array}{l}1976 \\
1977 \\
1978 \\
1979 \\
1980\end{array}$ & : & $\begin{array}{l}531.0 \\
560.2 \\
579.2 \\
598.3 \\
613.5\end{array}$ & $\begin{array}{l}2,038 \\
2,124 \\
2,206 \\
2,247 \\
2,286\end{array}$ & $\begin{array}{l}1,855 \\
1,948 \\
2,018 \\
2,071 \\
2,094\end{array}$ & $\begin{array}{l}3.73 \\
4.05 \\
4.31 \\
4.64 \\
5.36\end{array}$ & $\begin{array}{l}2.82 \\
2.89 \\
2.87 \\
2.84 \\
3.00\end{array}$ & $\begin{array}{l}3.09 \\
3.42 \\
3.69 \\
3.99 \\
4.73\end{array}$ & $\begin{array}{l}2.33 \\
2.44 \\
2.45 \\
2.44 \\
2.65\end{array}$ \\
\hline $\begin{array}{l}1981 \\
1982 \\
1983 \\
1984\end{array}$ & & $\begin{array}{l}634.8 \\
650.1 \\
658.2 \\
672.0\end{array}$ & $\begin{array}{l}2,295 \\
2,241 \\
2,310 \\
2,413\end{array}$ & $\begin{array}{l}2,147 \\
2,086 \\
2,151 \\
2,282\end{array}$ & $\begin{array}{l}6.20 \\
6.86 \\
7.18 \\
7.56\end{array}$ & $\begin{array}{l}3.17 \\
3.31 \\
3.33 \\
3.38\end{array}$ & $\begin{array}{l}5.46 \\
6.13 \\
6.29 \\
6.52\end{array}$ & $\begin{array}{l}2.79 \\
2.96 \\
2.92 \\
2.92\end{array}$ \\
\hline
\end{tabular}

- 1902 data U.S. Bureau of the Census, Historical Statistics of the United States, Colonlal Times to 1970, Blcentennial Editlon, Part 2 (1975), p. 827; 1907-1959, Edison Electric Institute (EEI), Historlcal Statistics of the Electric Utility Industry Through 1970 (1970), p. 165; 1960-1984, Energy Information Administration, Annual Energy Review 1984 (AER), p. 187. Comparably defined EEI data for 1960-1970 are about 6 percent above ElA data shown in this table for the same year. As a result, apparent price increases shown in the table between 1959 and 1960 reflect changes in the data series and not real price increases.

- 1902-1948 data are from Edison, p. 2. 1949-1984 data are from EIA, AER 84, p. 181.

- 1902-1948 data are from Edison, p. 24. 1949-1984 data are from AER 84, p. 171.

- 1926-1948 data are from Edison, p. 60. 1949-1984 data are from AER 84, p. 179 (Note: Comparably defined EEI data for 1949-1960 are consistently about 3 percent below EIA data shown in this table for the same years).

- Constant prices calculated in 1972 dollars.

NA $=$ Not available. 


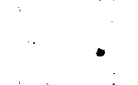




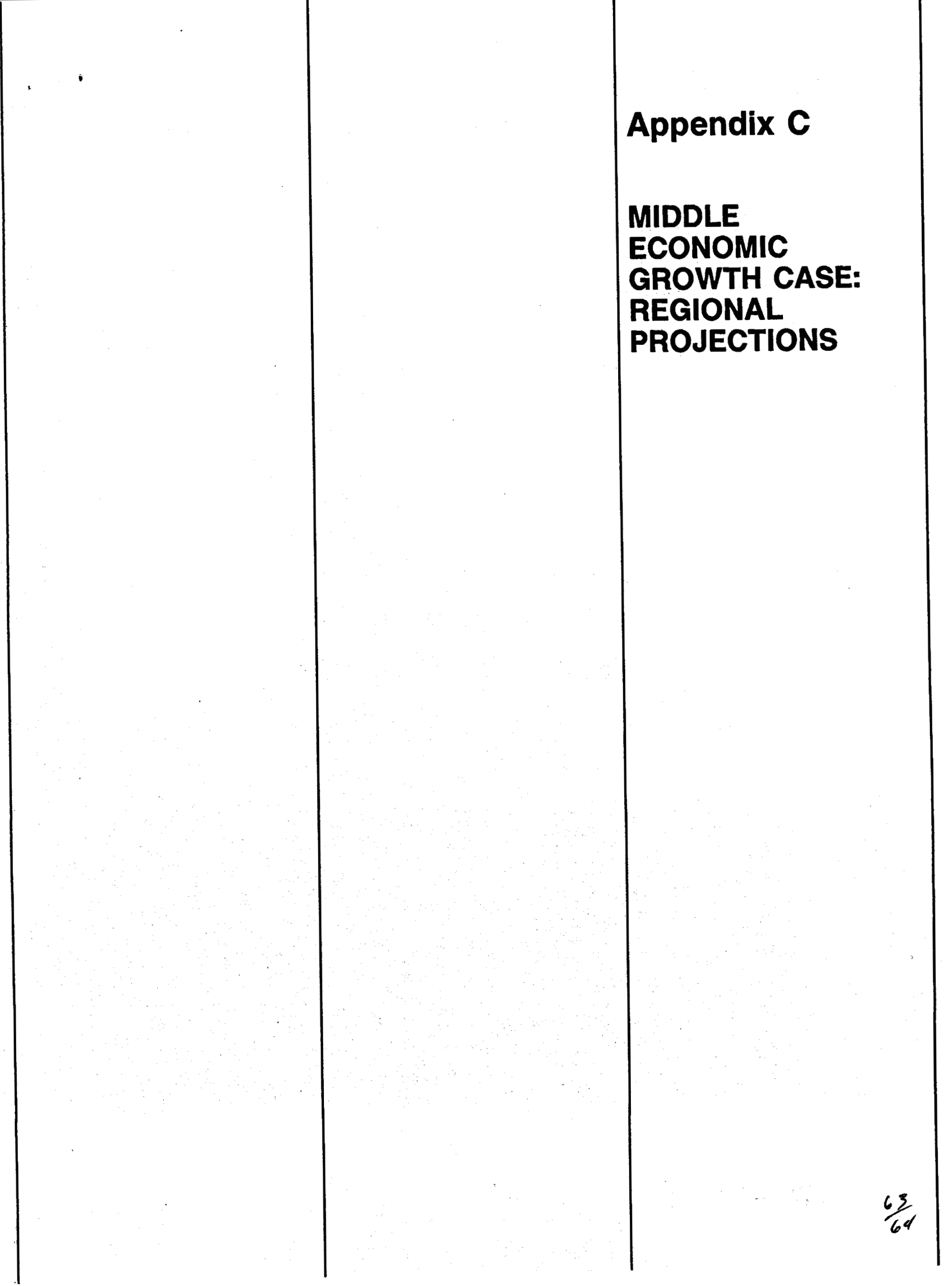


. 


\section{MIDDLE ECONOMIC GROWTH CASE: REGIONAL PROJECTIONS}

The following tables present Federal regional projections for U.S. electricity demand, price, capacity, and generation. The first table, $\mathrm{Cl}$, identifies the States comprising each of the 10 Federal Regions; tables C2C11 contain the regional projections. The projections in these tables are consistent with the base case national projections summarized in the Annual Energy Outlook. However, regional projections are more uncertain than the national projections because of lower level of aggregation for each fuel and sector. These regional projections are intended to be used as indices for interregional comparisons.

Table C1. The U.S. Federal Reglons

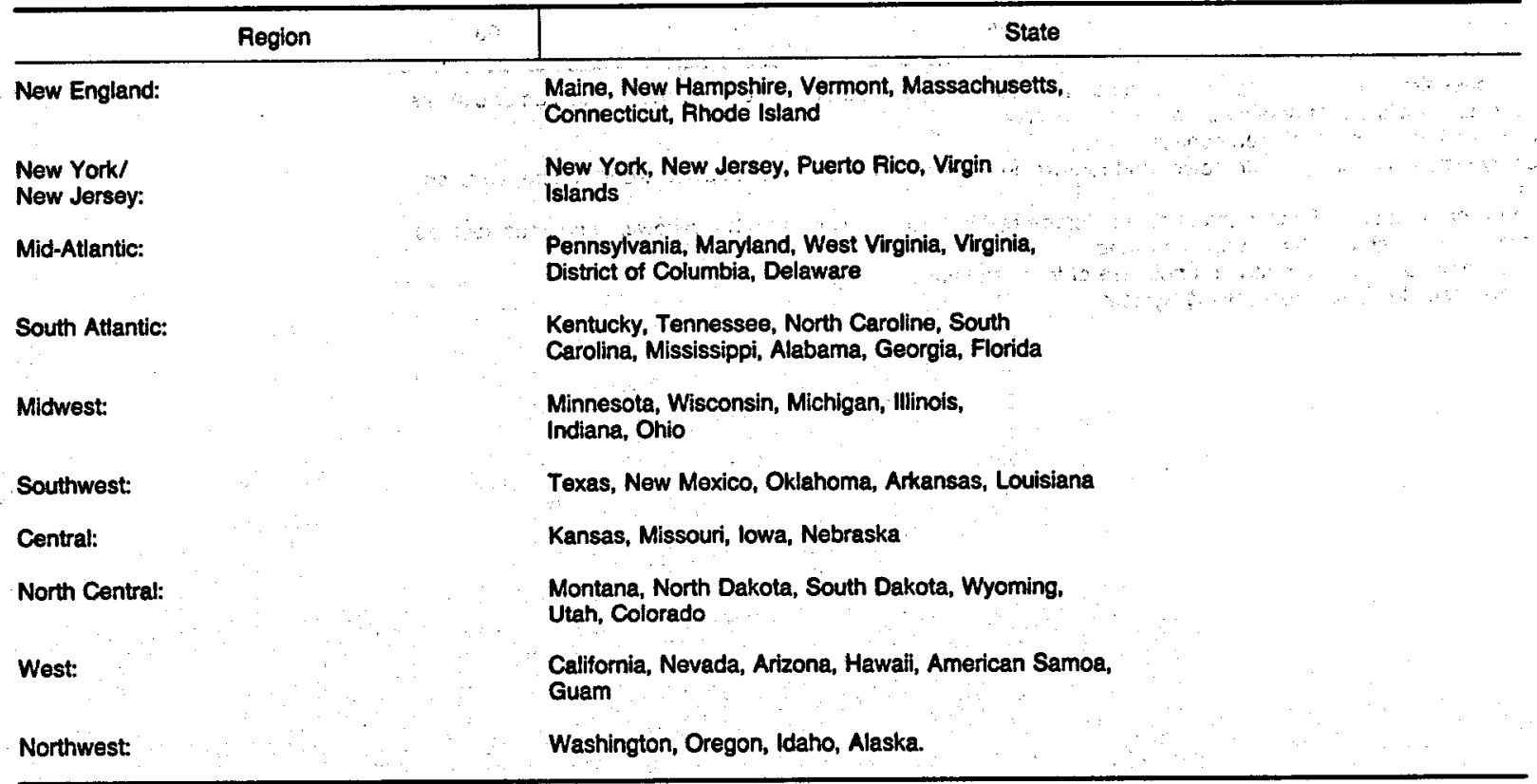


Table C2. New England: Projections of Electricity Demand, Price, Generating Capaclty, and Generation, 1985, 1990, 1995

\begin{tabular}{|c|c|c|c|c|}
\hline \multirow{2}{*}{ Forecast Elements } & \multicolumn{4}{|c|}{ Middle Economic Growth Case } \\
\hline & 1985 & & 1990 & 1995 \\
\hline $\begin{array}{l}\text { Electriclty Demand } \\
\text { (billion kWh per year) }\end{array}$ & 88.4 & & 98.9 & 111.1 \\
\hline $\begin{array}{l}\text { Electricity Price" } \\
\text { (1984 dollars per thousand kWh) }\end{array}$ & 82.87 & & 88.19 & 88.38 \\
\hline $\begin{array}{l}\text { Nameplate Capacity" } \\
\text { (million kW) } \\
\text { Coal Steam } \\
\text { Other Steam" } \\
\text { Combined Cycle } \\
\text { Turbine } \\
\text { Nuclear Power } \\
\text { Hydropower/Other } \\
\text { Pumped Storage Hydropower }\end{array}$ & $\begin{array}{r}1.6 \\
10.1 \\
0.4 \\
1.5 \\
4.3 \\
1.5 \\
1.6\end{array}$ & & $\begin{array}{r}1.6 \\
10.1 \\
0.4 \\
1.5 \\
6.6 \\
1.5 \\
1.6\end{array}$ & $\begin{array}{r}1.6 \\
10.1 \\
0.4 \\
1.5 \\
7.8 \\
1.5 \\
1.6\end{array}$ \\
\hline Total Capacity & 20.9 & & 23.4 & 24.6 \\
\hline $\begin{array}{l}\text { Generation by Fuel Type } \\
\text { (billion kWh per year) } \\
\text { Coal } \\
\text { Natural Gas } \\
\text { Oil } \\
\text { Nuclear Power } \\
\text { All Hydropower/Other }\end{array}$ & $\begin{array}{r}12 \\
3 \\
42 \\
22 \\
4\end{array}$ & , & $\begin{array}{r}11 \\
3 \\
35 \\
36 \\
5\end{array}$ & $\begin{array}{r}11 \\
4 \\
40 \\
44 \\
5\end{array}$ \\
\hline Total Generation & 84 & & 91 & 103 \\
\hline
\end{tabular}

- Prices are model simulations and represent average revenues per kilowatthour of demand over all customer classes.

- Capacity excludes units out of service or in inactive reserve.

- Other includes oil, gas, and dual-fired capacity.

- This category includes pondage hydropower and renewable sources such as thermal power, wood, waste, solar energy, and wind.

This category includes conventional and pumped storage hydroelectric power and other renewable sources such as geothermal power, wood waste, solar energy, and wind.

Note: Total may not equal sum of parts because of independent rounding.

Source: Intermediate Future Forecasting System. 
Table C3. New York/New Jersey: Projections of Electriclty

$\therefore \quad$ Demand, Price, Generating Capacity, and Generation, 1985, 1990, 1995

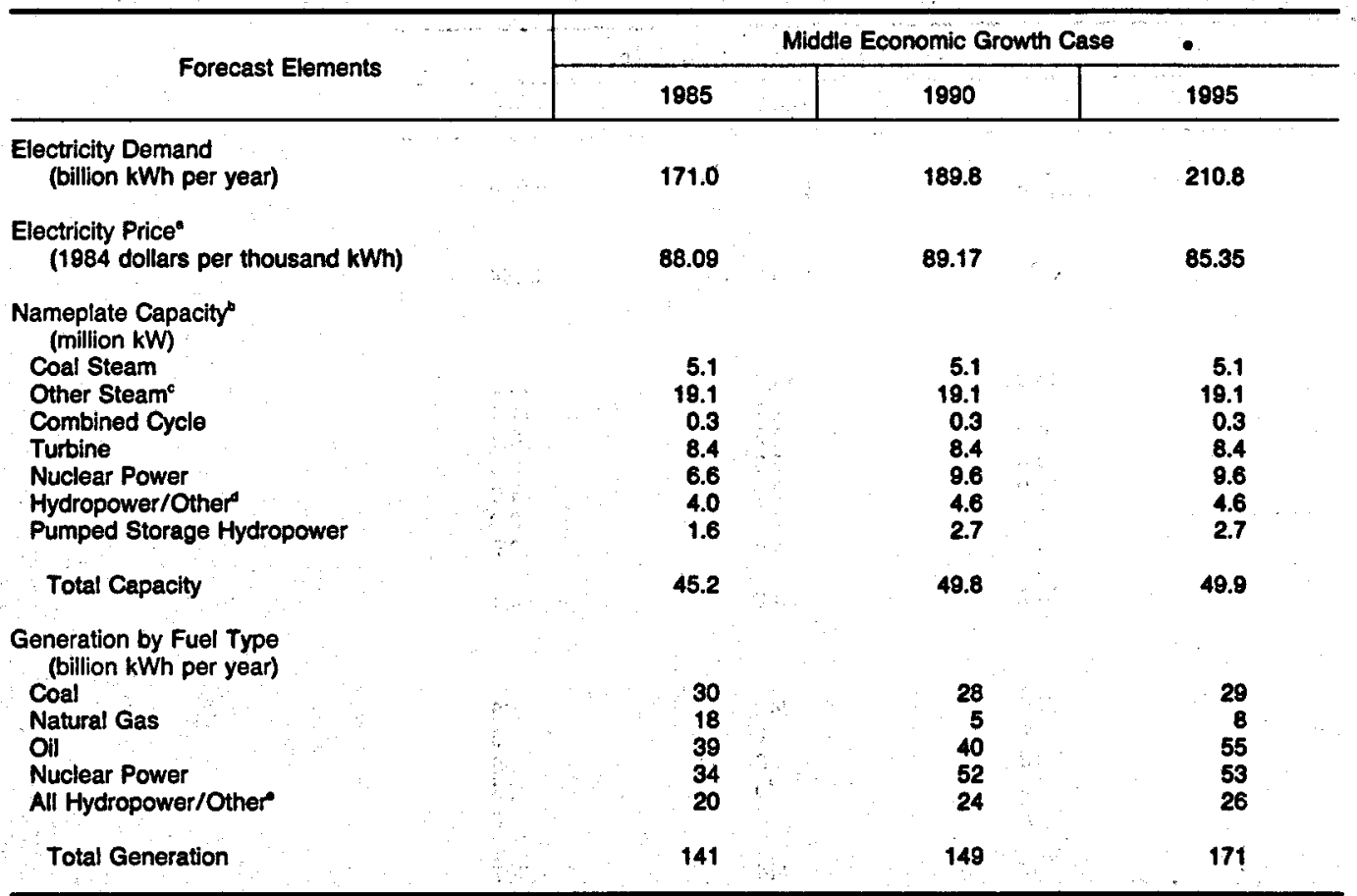

- Prices are model simulations and represent average revenues per kilowatthour of demand over all customer classes.

- Capacity excludes units out of service or in inactive reserve.

- Other includes oil, gas, and dual-fired capacity.

- This category includes pondage hydropower and renewable sources such as thermal power, wood, waste, solar energy, and wind.

This category includes conventional and pumped storage hydroelectric power and other renewable sources such as geothermal power, wood waste, solar energy, and wind.

Note: Total may not equal sum of parts because of independent rounding.

Source: Intermediate Future Forecasting System. 
Table C4. Mid-Atlantic: Projections of Electricity Demand, Price, Generating Capacity, and Generation, $1985,1990,1995$

\begin{tabular}{|c|c|c|c|c|}
\hline \multirow{2}{*}{ Forecast Elements } & & \multicolumn{3}{|c|}{ Middle Economic Growth Case } \\
\hline & & 1985 & 1990 & 1995 \\
\hline \multicolumn{5}{|l|}{$\begin{array}{l}\text { Electricity Demand } \\
\text { (billion kWh per year) }\end{array}$} \\
\hline $\begin{array}{l}\text { Electricity Price" } \\
\text { (1984 dollars per thousand kWh) }\end{array}$ & & 66.91 & 64.78 & 65.54 \\
\hline \multicolumn{5}{|l|}{$\begin{array}{l}\text { Nameplate Capacity" } \\
\text { (million } \mathrm{kW} \text { ) }\end{array}$} \\
\hline $\begin{array}{l}\text { Coal Steam } \\
\text { Other Steam } \\
\text { Combined Cycle } \\
\text { Turbine } \\
\text { Nuclear Power } \\
\text { Hydropower/Other" } \\
\text { Pumped Storage Hydropower }\end{array}$ & : & $\begin{array}{r}43.0 \\
11.1 \\
0.3 \\
5.0 \\
11.0 \\
1.9 \\
2.9\end{array}$ & $\begin{array}{r}44.3 \\
11.1 \\
0.3 \\
5.0 \\
12.9 \\
2.0 \\
3.6\end{array}$ & $\begin{array}{r}48.2 \\
11.1 \\
0.3 \\
5.0 \\
14.0 \\
2.0 \\
3.6\end{array}$ \\
\hline Total Capacity & - & 75.2 & 79.2 & 84.1 \\
\hline \multicolumn{5}{|l|}{$\begin{array}{r}\text { Generation by Fuel Type } \\
\text { (billion kWh per year) }\end{array}$} \\
\hline $\begin{array}{l}\text { Coal } \\
\text { Natural Gas } \\
\text { Oil } \\
\text { Nuclear Power } \\
\text { All Hydropower/Other }\end{array}$ & : & $\begin{array}{r}220 \\
2 \\
19 \\
55 \\
2\end{array}$ & $\begin{array}{r}242 \\
2 \\
28 \\
70 \\
2\end{array}$ & $\begin{array}{r}268 \\
3 \\
38 \\
76 \\
2\end{array}$ \\
\hline Total Generation & & 297 & 344 & 387 \\
\hline
\end{tabular}

- Prices are model simulations and represent average revenues per kilowatthour of demaind over all customer classes.

- Capacity excludes units out of service or in inactive reserve.

c Other includes oil, gas, and dual-fired capacity.

- This category includes pondage hydropower and renewable sources such as thermal power, wood, waste, solar energy, and wind.

This category includes conventional and pumped storage hydroelectric power and other renewable sources such as geothermal power, wood waste, solar energy, and wind.

Note: Total may not equal sum of parts because of independent rounding

Source: Intermediate Future Forecasting System. 
Table C5. South Atlantic: Projections of Electriclty Demand, Price, Generating Capacity, and Generation, 1985, 1990, 1995

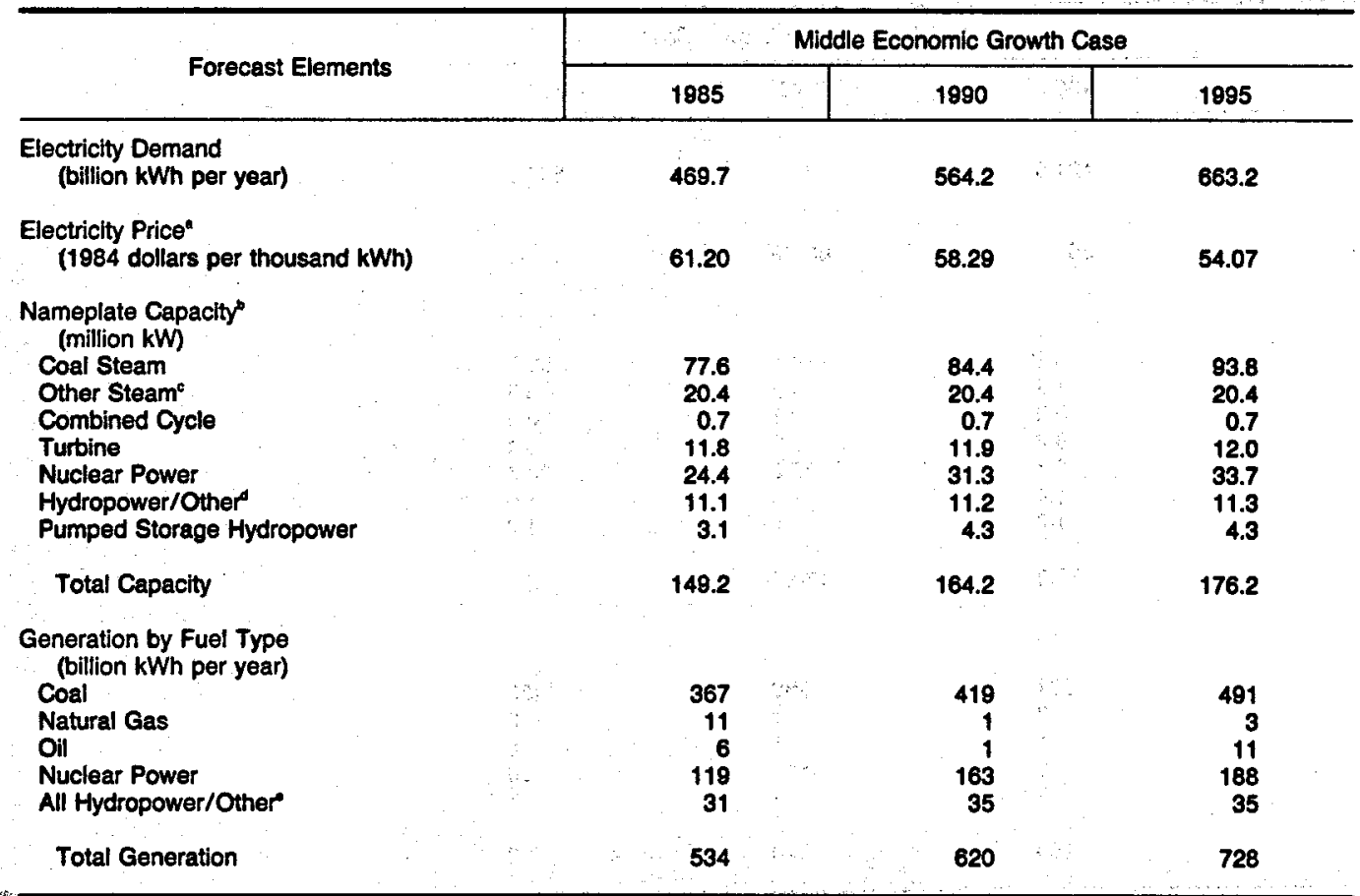

- Prices are model simulations and represent average revenues per kilowatthour of demand over all customer classes.

- Capacity excludes units out of service or in inactive reserve.

- Other includes oil, gas, and dual-fired capacity.

- This category includes pondage hydropower and renewable sources such as thermal power, wood, waste, solar energy, and wind.

- This category includes conventional and pumped storage hydroelectric power and other renewable sources such as geothermal power, wood waste, solar energy, and wind

Note: Total may not equal sum of parts because of independent rounding.

Source: Intermediate Future Forecasting System. 
Table C6. Midwest: Projections of Electricity Demand, Price, Generating Capacity, and Generation, $1985,1990,1995$

\begin{tabular}{|c|c|c|c|c|}
\hline \multirow{2}{*}{ Forecast Elements } & \multicolumn{4}{|c|}{ Middle Economic Growth Case } \\
\hline & 1985 & & 1990 & 1995 \\
\hline $\begin{array}{l}\text { Electricity Demand } \\
\text { (billion kWh per year) }\end{array}$ & 421.8 & & 485.2 & 567.0 \\
\hline $\begin{array}{l}\text { Electricity Price" } \\
\text { (1984 dollars per thousand kWh) }\end{array}$ & 65.80 & & 63.69 & 57.80 \\
\hline $\begin{array}{l}\text { Nameplate Capacits" } \\
\text { (million kW) }\end{array}$ & & & & \\
\hline $\begin{array}{l}\text { Coal Steam } \\
\text { Other Steam } \\
\text { Combined Cycle } \\
\text { Turbine } \\
\text { Nuclear Power } \\
\text { Hydropower/Other } \\
\text { Pumped Storage Hydropower }\end{array}$ & $\begin{array}{r}86.1 \\
6.9 \\
0.3 \\
8.2 \\
16.7 \\
1.4 \\
1.7\end{array}$ & & $\begin{array}{r}89.4 \\
6.9 \\
0.3 \\
8.3 \\
22.2 \\
1.5 \\
1.7\end{array}$ & $\begin{array}{r}90.7 \\
6.9 \\
0.3 \\
8.4 \\
23.4 \\
1.5 \\
1.7\end{array}$ \\
\hline Total Capacity & 121.2 & & 130.2 & 132.8 \\
\hline $\begin{array}{l}\text { Generation by Fuel Type } \\
\text { (billion kWh per year) }\end{array}$ & & & & \\
\hline $\begin{array}{l}\text { Coal } \\
\text { Natural Gas } \\
\text { Oil } \\
\text { Nuclear Power } \\
\text { All Hydropower/Other }\end{array}$ & $\begin{array}{r}361 \\
3 \\
1 \\
80 \\
5\end{array}$ & $\because$ & $\begin{array}{r}382 \\
1 \\
1 \\
119 \\
6\end{array}$ & $\begin{array}{r}458 \\
3 \\
6 \\
130 \\
6\end{array}$ \\
\hline Total Generation & 450 & & 510 & 603 \\
\hline
\end{tabular}

- Prices are model simulations and represent average revenues per kilowatthour of demand over all customer classes.

- Capacity excludes units out of service or in inactive reserve.

- Other includes oil, gas, and dual-fired capacity.

This category includes pondage hydropower and renewable sources such as thermal power, wood, waste, solar energy, and wind.

- This category includes conventional and pumped storage mydroelectric power and other renewable sources such as geothermal power, wood waste, soler energy, and wind.

Note: Total may not equal sum of parts because of independent rounding.

Source: Intermediate Future Forecasting System. 
Table C7. Southwest: Projections of Electricity Demand, Price, Generating Capacity, and Generation, 1985, 1990, 1995

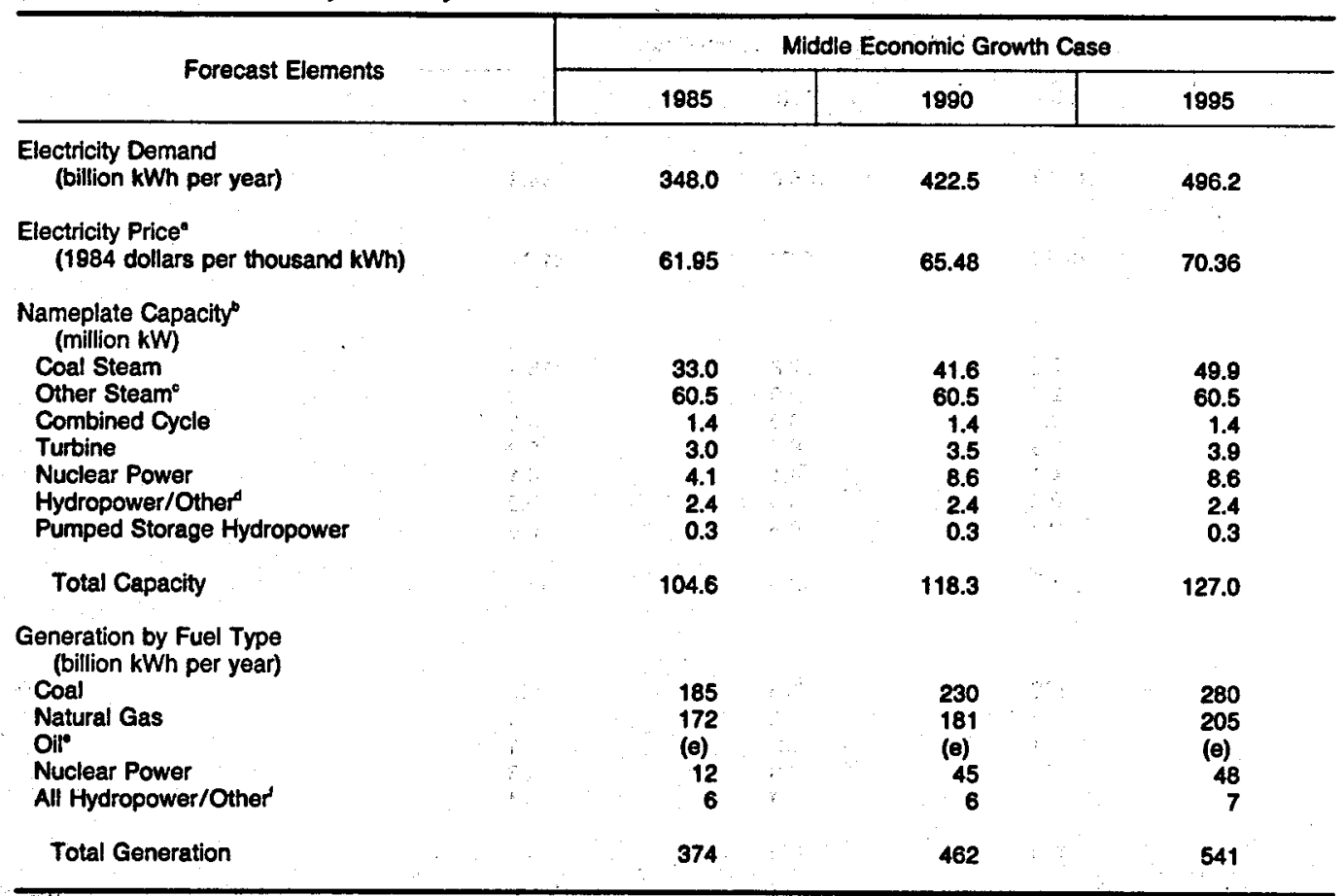

Prices are model simulations and represent average revenues per kilowatthour of demand over all customer classes.

Capacity excludes units out of service or in inactive reserve.

Other includes oil, gas, and dual-fired capacity.

- This category includes pondage hydropower and renewable sources such as thermal power, wood, waste, solar energy, and wind.

Less than 0.5 billion kilowatthours per year.

- This category includes conventional and pumped storage hydroelectric power and other renewable sources such as geothermal power, wood waste, solar energy, and wind.

Note: Total may not equal sum of parts because of independent rounding.

Source: Intermediate Future Forecasting System. 
Table C8. Central: Projections of Electricity Demand, Price, Generating Capacity, and Generation, $1985,1990,1995$

\begin{tabular}{|c|c|c|c|}
\hline \multirow{2}{*}{ Forecast Elements } & \multicolumn{3}{|c|}{ Middle Economic Growth Case } \\
\hline & 1985 & 1990 & 1895 \\
\hline $\begin{array}{l}\text { Electricity Demand } \\
\text { (billion KWh per year) }\end{array}$ & 110.8 & 125.6 & 144.3 \\
\hline $\begin{array}{l}\text { Electricity Price" } \\
\text { (1984 dollars per thousand kWh) }\end{array}$ & 70.12 & 65.77 & 61.00 \\
\hline $\begin{array}{l}\text { Nameplate Capacity" } \\
\text { (million } \mathrm{kW} \text { ) }\end{array}$ & & & \\
\hline $\begin{array}{l}\text { Coal Steam } \\
\text { Other Steam } \\
\text { Combined Cycle } \\
\text { Turbine } \\
\text { Nuclear Power } \\
\text { Hydropower/Other } \\
\text { Pumped Storage Hydropower }\end{array}$ & $\begin{array}{r}27.2 \\
2.8 \\
0.2 \\
5.9 \\
4.1 \\
0.9 \\
0.6\end{array}$ & $\begin{array}{r}27.8 \\
2.8 \\
0.2 \\
6.2 \\
4.1 \\
0.9 \\
0.6\end{array}$ & $\begin{array}{r}28.6 \\
2.8 \\
0.2 \\
6.3 \\
4.1 \\
0.9 \\
0.6\end{array}$ \\
\hline Total Capacity & 41.7 & 42.6 & 43.5 \\
\hline $\begin{array}{l}\text { Generation by Fuel Type } \\
\text { (billion kWh per year) }\end{array}$ & & & \\
\hline $\begin{array}{l}\text { Coal } \\
\text { Natural Gas } \\
\text { Oi" } \\
\text { Nuclear Power } \\
\text { All Hydropower/Other' }\end{array}$ & $\begin{array}{r}103 \\
2 \\
1 \\
15 \\
3\end{array}$ & $\begin{array}{r}115 \\
2 \\
(e)^{2} \\
23 \\
4\end{array}$ & $\begin{array}{r}132 \\
4 \\
1 \\
23 \\
4\end{array}$ \\
\hline Total Generation & 125 & 143 & 164 \\
\hline
\end{tabular}

- Prices are model simulations and represent average revenues per kilowatthour of demand over all customer classes.

- Capacity excludes units out of service or in inactive reserve.

- Other includes oil, gas, and dual-fired capacity.

- This category includes pondage hydropower and renewable sources such as thermal power, wood, waste, solar energy, and wind.

Less than 0.5 billion kilowatthours per year.

- This category includes conventional and pumped storage hydroelectric power and other renewable sources such as geothermal power, wood waste, solar energy, and wind.

Note: Total may not equal sum of parts because of independent rounding.

Source: Intermediate Future Forecasting System. 
Table C9. North Central: Projections of Electriclty Demand,

.

Price, Generating Capacity, and Generation,

1985, 1990, 1995

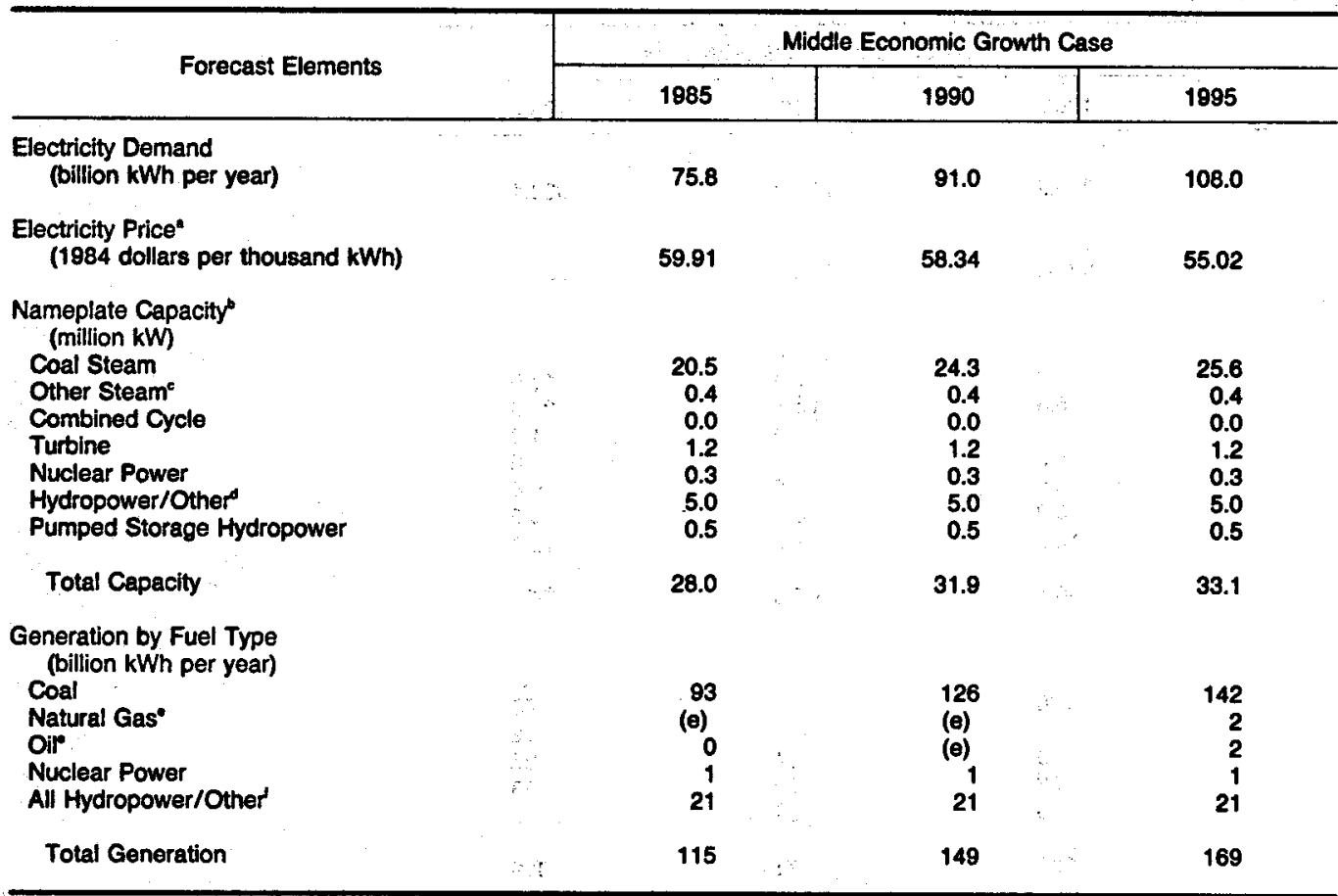

- Prices are model simulations and represent average revenues per kilowatthour of demand over all customer classes.

- Capacity excludes units out of service or in inactive reserve.

Other includes oil, gas, and dual-fired capacity.

- This category includes pondage hydropower and renewable sources such as thermal power, wood, waste, solar energy, and wind.

Less than 0.5 billion kilowatthours per year.

This category includes conventional and pumped storage hydroelectric power and other renewable sources such as geothermal power, wood waste, solar energy, and wind

Note: Total may not equal sum of parts because of independent rounding.

Source: Intermediate Future Forecasting System. 
Table C10. West: Projections of Electricity Demand, Price, Generating Capacity, and Generation, 1985, 1990, 1995

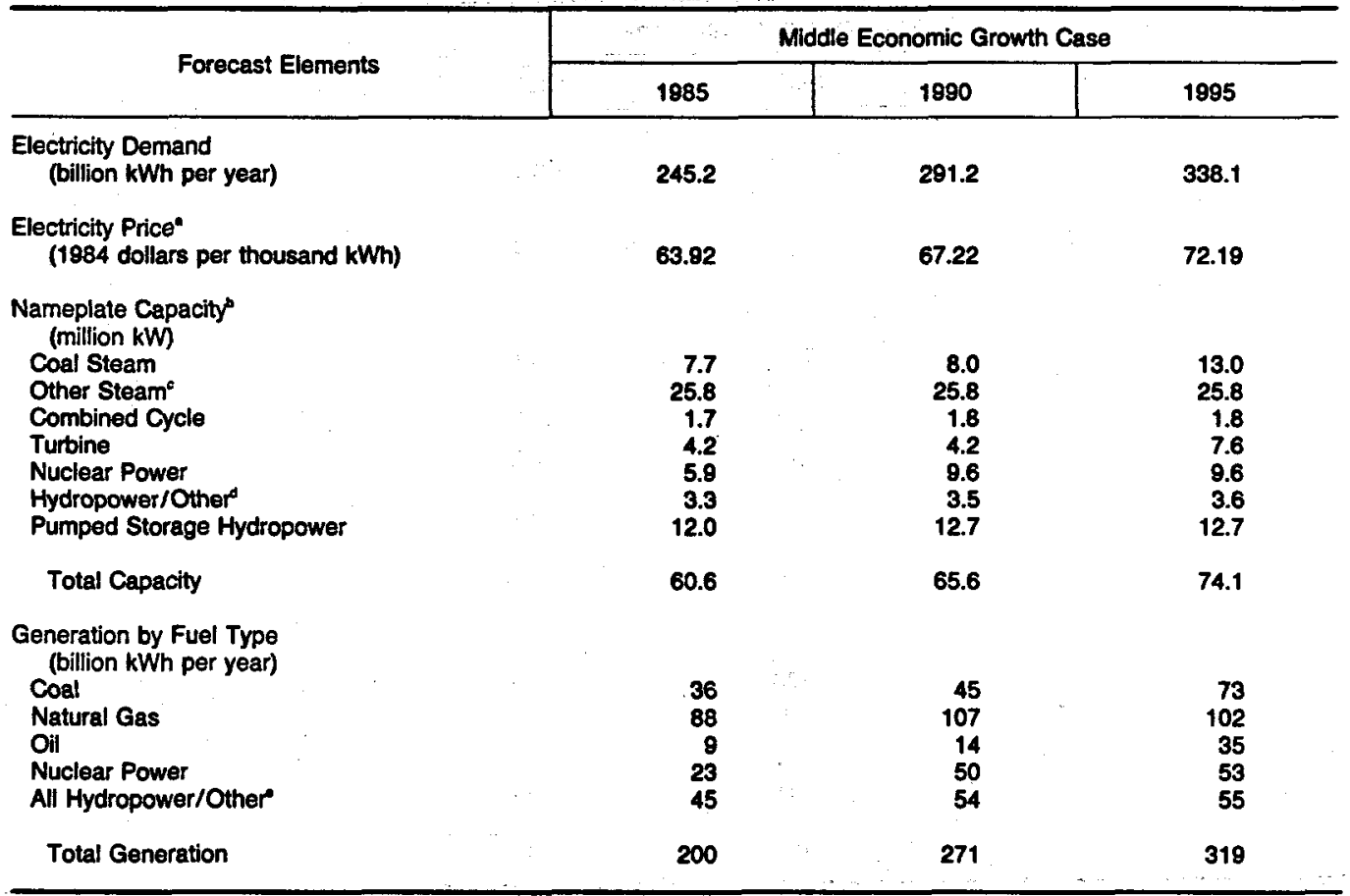

- Prices are model simulations and represent average revenues per kilowatthour of demand over all customer classes.

- Capacity excludes units out of service or in inactive reserve.

- Other includes oil, gas, and dual-fired capacity.

- This category includes pondage hydropower and renewable sources such as thermal power, wood, waste, solar energy, and wind.

- This category includes conventional and pumped storage hydroelectric power and other renewable sources such as geothermal power, wood waste, solar energy, and wind.

Note: Total may not equal sum of parts because of independent rounding.

Source: Intermediate Future Forecasting System. 
Table C11. Northwest: Projections of Electricity Demand,

Price, Generating Capacity, and Generation, $1985,1990,1995$

\begin{tabular}{|c|c|c|c|}
\hline \multirow{2}{*}{ Forecast Elements } & \multicolumn{3}{|c|}{ Middle Economic Growth Case } \\
\hline & 1985 & 1990 & 1995 \\
\hline $\begin{array}{l}\text { Electricity Demand } \\
\text { (billion kWh per year) }\end{array}$ & 154.1 & 191.8 & 225.5 \\
\hline $\begin{array}{l}\text { Electricity Pricea } \\
\text { (1984 dollars per thousand kWh) }\end{array}$ & 31.28 & 29.95 & 32.63 \\
\hline $\begin{array}{l}\text { Nameplate Capacity } \\
\text { (million kW) }\end{array}$ & & & \\
\hline $\begin{array}{l}\text { Coal Steam } \\
\text { Other Steam } \\
\text { Combined Cycle } \\
\text { Turbine } \\
\text { Nuclear Power } \\
\text { Hydropower/Other } \\
\text { Pumped Storage Hydropower }\end{array}$ & $\begin{array}{r}1.9 \\
0.2 \\
0.4 \\
2.2 \\
3.1 \\
30.8 \\
0.3\end{array}$ & $\begin{array}{r}1.9 \\
0.2 \\
0.4 \\
2.4 \\
4.3 \\
31.1 \\
0.3\end{array}$ & $\begin{array}{r}4.0 \\
0.2 \\
0.4 \\
4.7 \\
5.6 \\
31.1 \\
0.3\end{array}$ \\
\hline Total Capacity & 38.9 & 40.6 & 46.3 \\
\hline $\begin{array}{l}\text { Generation by Fuel Type } \\
\text { (billion } k W h \text { per year) }\end{array}$ & & & \\
\hline $\begin{array}{l}\text { Coal } \\
\text { Natural Gas } \\
\text { Oil } \\
\text { Nuclear Power } \\
\text { All Hydropower/Other }\end{array}$ & $\begin{array}{r}6 \\
2 \\
2 \\
12 \\
152\end{array}$ & $\begin{array}{r}11 \\
9 \\
1 \\
16 \\
151\end{array}$ & $\begin{array}{r}21 \\
16 \\
1 \\
28 \\
151\end{array}$ \\
\hline Total Generation & 174 & 188 & 217 \\
\hline
\end{tabular}

- Prices are model simulations and represent average revenues per kilowatthour of demand over all customer classes.

1. Capacity excludes units out of service or in inactive reserve.

- Other includes oil, gas, and dual-fired capacity.

- This category includes pondage hydropower and renewable sources such as thermal power, wood, waste, solar energy, and wind.

This category includes conventional and pumped storage hydroelectric power and other renewable sources such as geothermal power, wood waste, solar energy, and wind.

Note: Total may not equal sum of parts because of independent rounding.

Source: Intermediate Future Forecasting System. 
(For use in ordering EIA Publications only - Read Ordering Information Section before completing form.)

SEND ORDER FORM TO:|Superintendent of Documents, U.S. Government Printing Office, Washington, D.C., 20402

Enclosed is $\$$

$\square$ Check

Money order, or charge to my Deposit Account No.

\begin{tabular}{|l|l|l|l|l|l|}
\hline & & & & & \\
\hline
\end{tabular}

Order No.
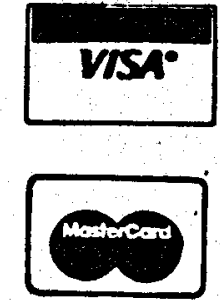

Credit Card Orders Only

Total charges \$ Fill in the boxes below

\begin{tabular}{ll|l|l|l|l|l|l|l|l|l|l|l|l|}
\hline Credit \\
Card No.
\end{tabular}

Expiration Date Month/Year

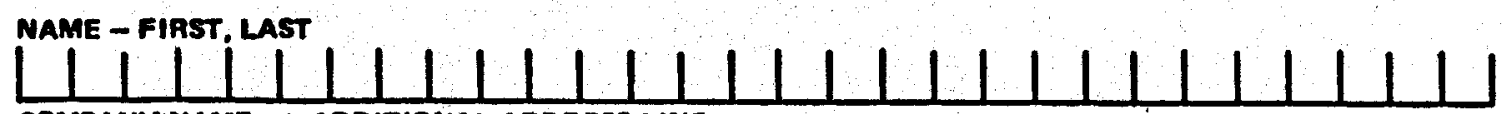

COMPANY NAME OR ADDITIONAL ADDRESS LINE

NAME AND ADDRESS

STAEET ADDAESS

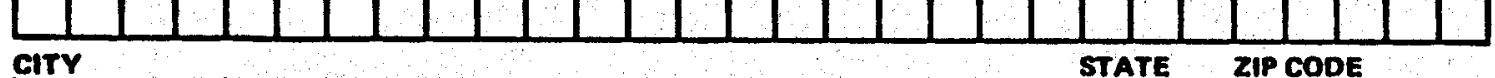

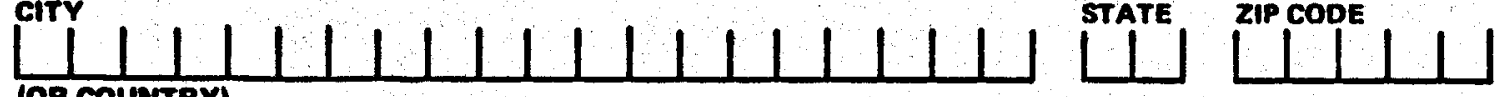

(OA COUNTAY)

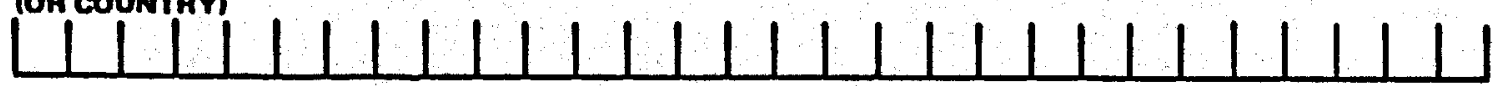

PLEASE PRINT OR TYPE THE GPO STOCK NO. OF SINGLE ISSUES OR ANNUALS YOU WISH TO RECEIVE:

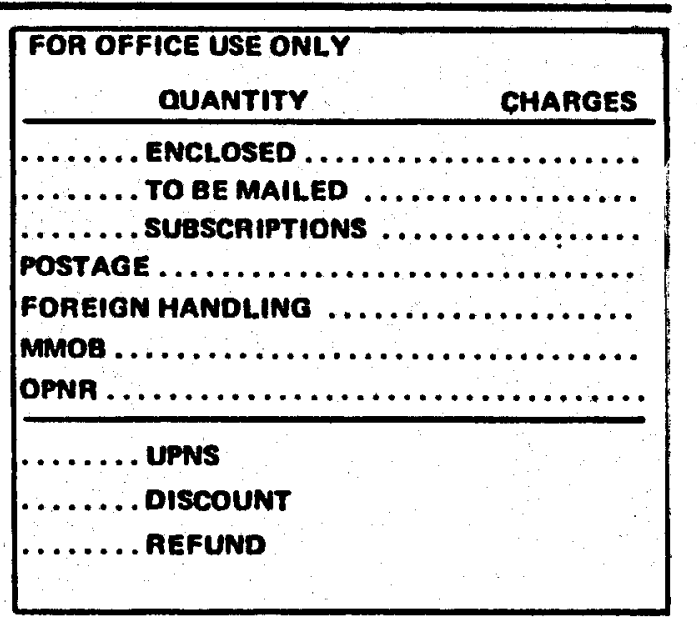

